\title{
أهمية الوقت والائتمان في التجارة بين القانون الوضعي والفقه الإسلامي دراسة نقدية مقارنة
}

\author{
دكثور \\ محممل كمال سالم \\ مدرس القانون التجاري والبحري \\ كلية الحقوق - جامعة عين شمس التئس
}





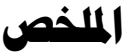

ترتكز التجارة على أساسين؛ هما مر اعاة الوقت تمشيا مع السرعة التي تتميز بها التجارة ومعاملاتها، و الإئمان و الثقة اللازمين لتوكيد وتدعيم تلك المعاملات، وقد وضع قانون التجارة رقم V لسنة 1999 العديد من القواعد التي راعت هذين الأساسين، كما أن الثريعة الإسلامية ليست من ذلك ببعيد وكيف لا وهي شريعة رب العباد الخبير بما يصلحهم ويصلح لهم في الدنيا و الآخرة، ففيها من القو اعد ما يحقق هذين الأساسين، وذلك بالر غم من أن الفقه الإسلادي لم يفرق بين المعاملات المدنية والتجارية إلا أنه مع ذللك وضع قو اعد تخص أعمال التجارة خصوصـا. وفي ضوء ما سبق أجريت مقارنة بين أحكام قانون التجارة المتعلقة بموضوع البحث في محاولة للإجابة على التساؤلات الآتية: اــ مدى جدوى التفرقة بين العمل التجاري و العمل المدني و المعدول بها في

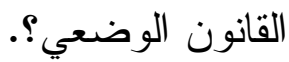
Y- مدى مر اعاة قانون التجارة رقم V ل لسنة 1999 لمصالح أطراف

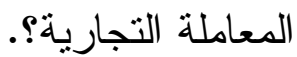

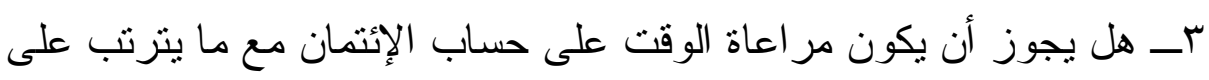

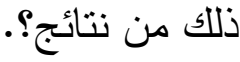
عـ و أيهما يحقق الإئتمان - بل السلام الإجتماعي في الدولة ـ حصول كل طرف على حقه أم إتمام المعاملة وتسويتها بما يحقق مصلحة الطرف القوي؟. 0ـ هل توجد في الثريعة الإسلامية قو اعد تز اعي الوقت و الإئتمان في التجارة، أم أن لا توجد منل تللك القو اعد لعدم تفرقة الفقه الإسلامي المعاملات

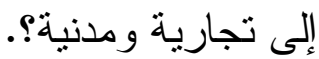
T- وفي حال وجود تللك القو اعد، فهل حققت التوازن بين مصالح الأطر اف؟. V- و إذا كانت قد حققتها، فلماذا لم نأخذ بها في القانون الوضعي؟. 


\section{تمهيد وتهديد}

تتعدد الأسس التي تقوم عليها التجارة سواء في القانون الوضعي أو في

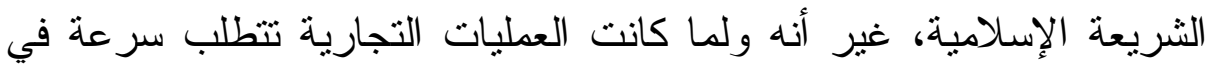
تتفيذها ودعم للتقة والائتمان بين القائمين عليها من التجار ، فقد الهنم القانون

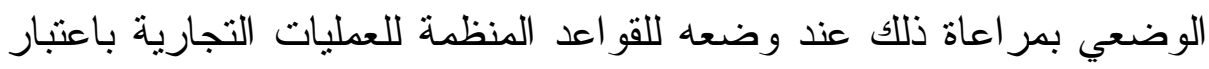

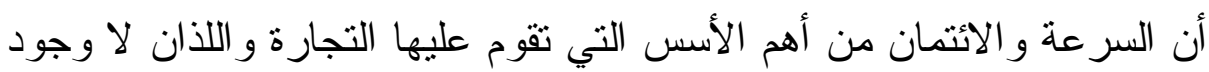
لهما في البيئة المدنية. فلا يكاد يخلو كتاب في فقه القانون التجاري عند تبريره لاستقلال القانون التجاري عن القانون المدني بقو اعد خاصة، و إلا ويستند في ذللك الي أن طبيعة

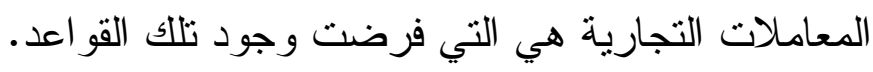

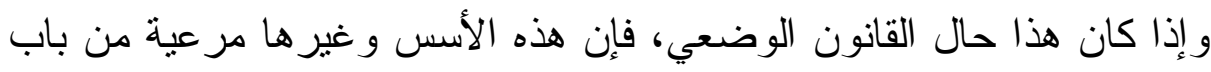

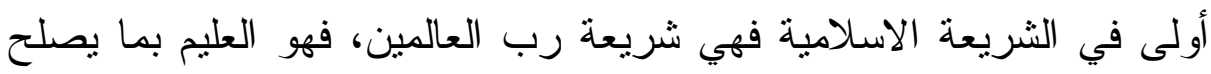

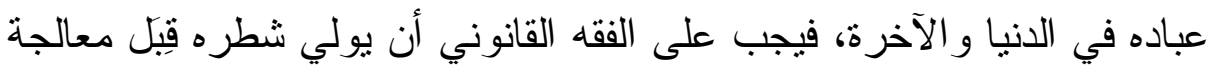
الفقه الإسلامي للمعاملات أيا كانت طبيعتها مدنية أم تجارية دون تمييز بينهما، حيث لم يميز الفقه الاسلامي بين المعاملات التجارية و المدنية و لا بين التاجر و غيره كما هو الحال في الفقه القانوني الوضعي، و عدم التمبيز هذا مقصود

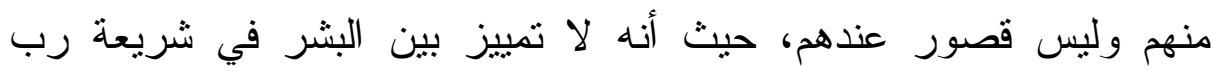
العالمين، قال تعالى "إن أكرمكم عند الله أتقاكم" .

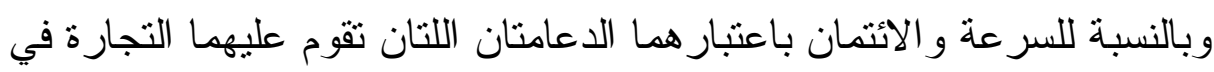
نظر فقه القانون الوضعي، نجد أن هناك العديد من الأحكام و القواعد في

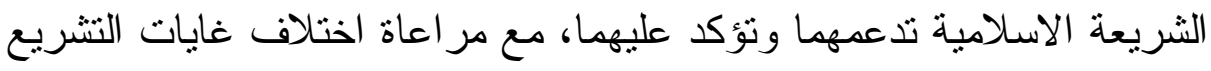

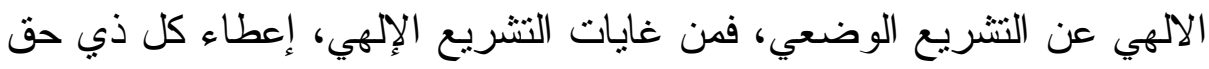

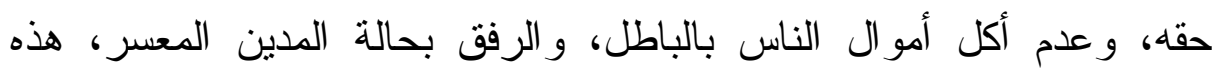
الغايات لا وجود لها في كثير من القواعد المنظمة للمعاملات التجارية في

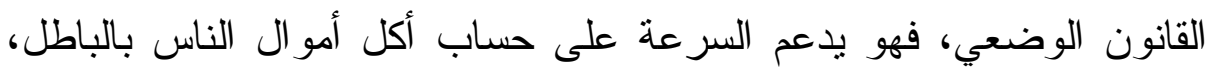

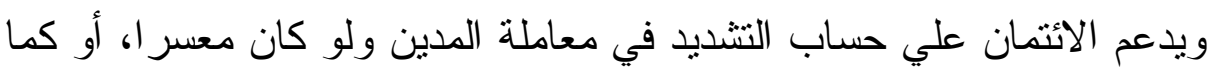

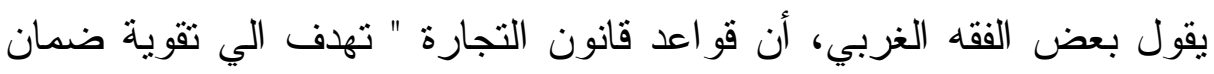

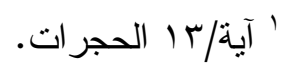




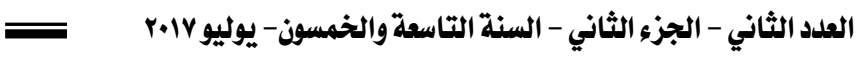

الائنين من كبار التجار، تللك القواعد التي فرضها كبار التجار لتحقيق أقصى

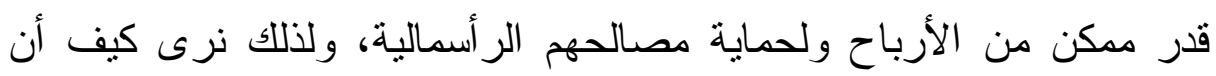
القانون التجاري يعكس في الواقع تتاقض وصن الإن ولهاع المصالح المختلفة، مصالح

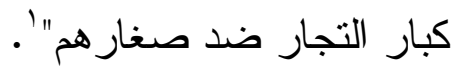

وسيأتي معالجة هذا البحث في فصلين؛ الأول منهما سأتتاول فيه أهمية الوقت

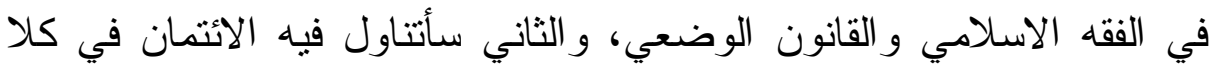
منهما أيضا.

${ }^{1}$ Gerard Lyon-Caen : contribution a la recherche d'une definition du droit Commercial.

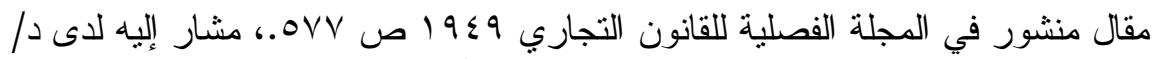

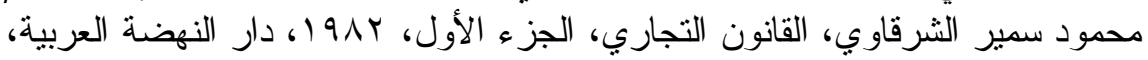
صن. 


\section{الفصل الأول \\ أهمية الوقت في الفقه الإسلاهي والقانون الوالول الوضعي}

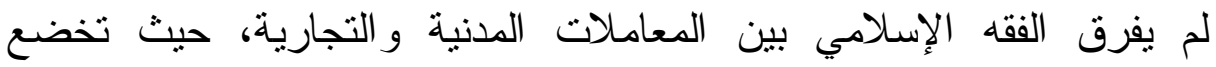
المعاملات أيا كانت طبيعتها لأحكام وقو اعد واحدة دون وضع قو اعد تخص

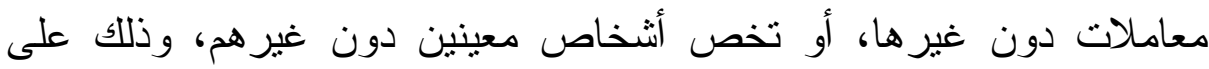
عكس الحال في القانون الوضعي الذي خص المعاملات التجان التهارية بأحكام وقو اعد دون المعاملات المدنية، كما خص التجار بأحكام وقو اعد دون غير هم

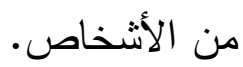

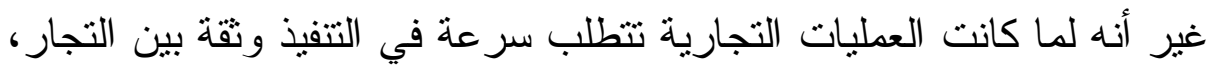
وأن العمل التجاري كثير التكرر، فقد يتعاقد الثخص على أكثر من صفقة تجارية في اليوم الواحد، الأمر الذي يصعب معه نوثنقها و الإشهاد عليها، لذلك

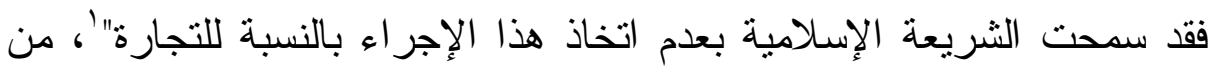

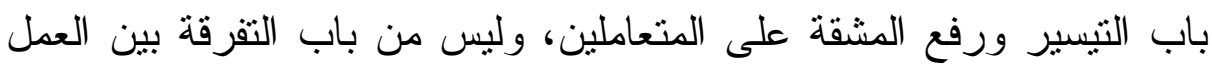

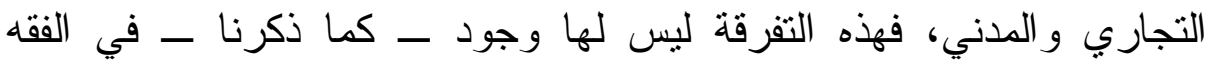

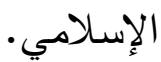

فإذا كان القانون الوضعي وضع أحكام وقو اعد راعى فيها أهمية الوقت بحيث

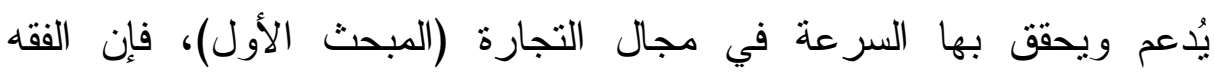

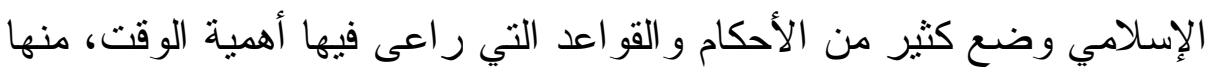

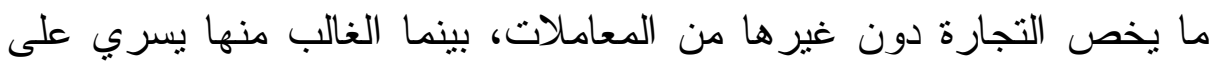

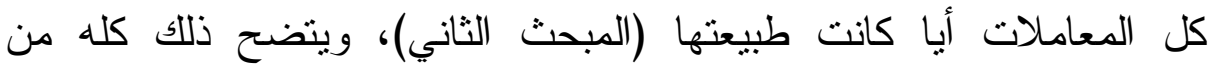
المقارنة بين الفقه الإسلامي و القانون الوضعي في هذا الصدد(المبحث الثالث).

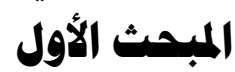

\section{بهض القواعد التي راعى فيدها القانون الوضهي أهسية الوقية الوقت}

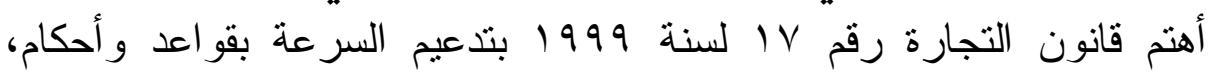
باعتبار أن مر اعاة الوقت من أهم الأسس التي تقوم عليها التجارة، حتى ولو التو كان في سبيل تحقيق ذلك؛ الجنوح إلى حماية الدائن على الهى حساب المدين

' د د/سعيد أبو الفتوح، المعاملات التجارية وضو ابطها الثرعية، دار نصر للطباعة الحديثة،

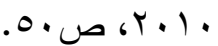


الضعيف"'، بل ولو أدى تحقيق ذلك أكل أموال الناس بالباطل، وتتضح تلك إلك

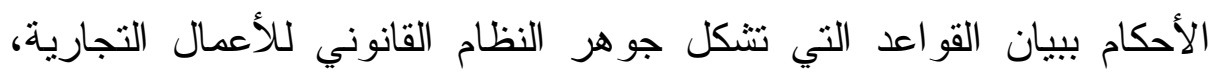

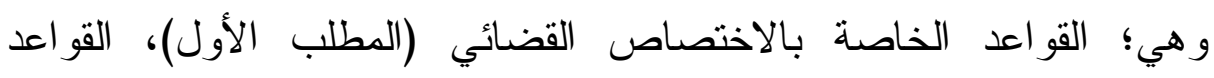
الخاصة بالإثبات (المطلب الثاني)، و القو اعد الخاصة بالالنز امات التجارية

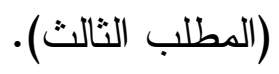

\section{الاطباب الأول الاختصاص القضائي}

أولا : الاختصاص النوعي

مع مر اعاة المنازعات التجارية التي تختص التص بها المحاكم الاقتصادية؛ تثور

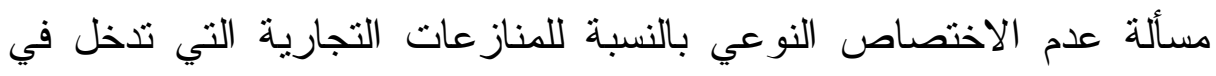

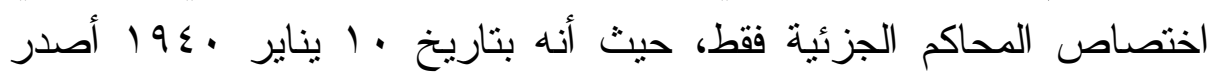

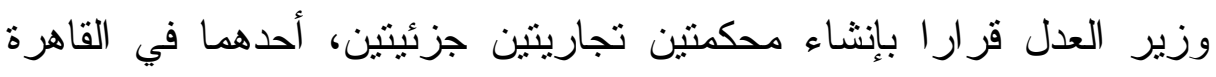

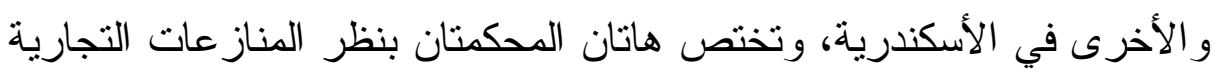

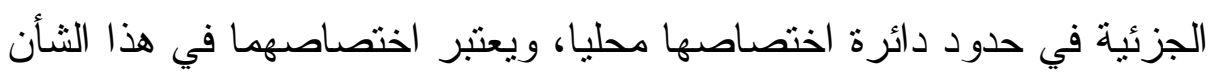

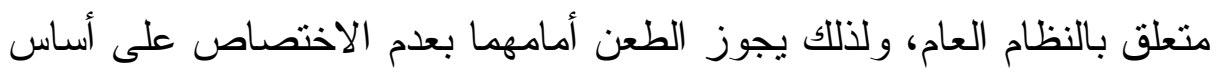

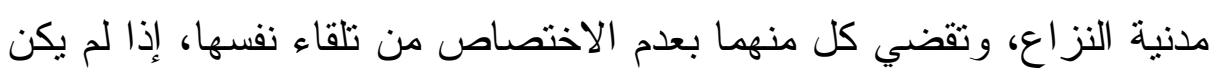

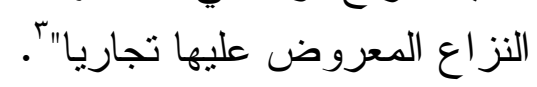
أما بالنسبة للمنازعات التي تدخل في اختصاص المحاكم الابتدائية، فلا يثور

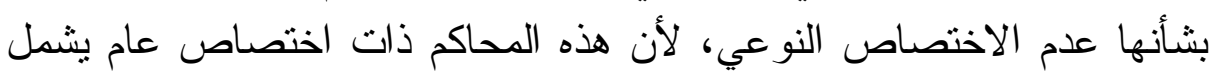
المنازعات المدنية و التجارية، على أن العمل جرى لأن على تلى لخصيص دو ائر

'دم/محود سمير الثرقاوي، القانون التجاري، الجزء الأول، دار النهضة العربية،

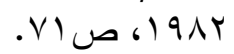

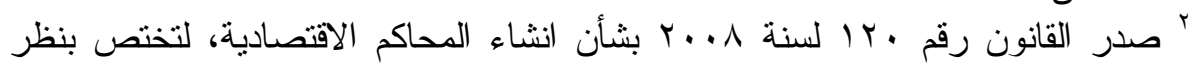

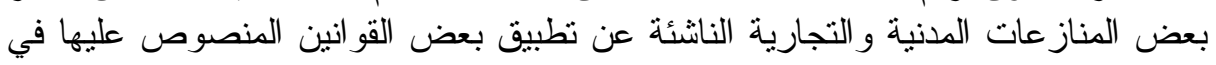

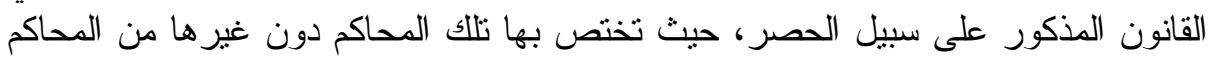

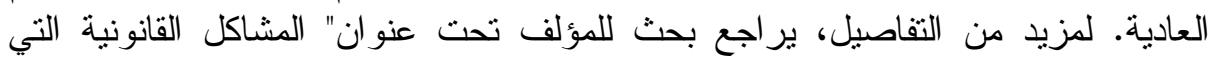

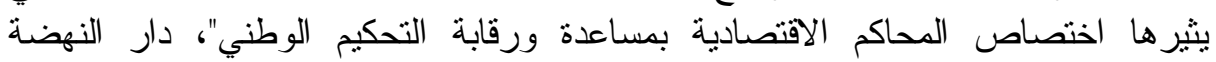

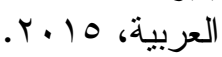

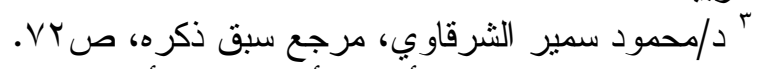

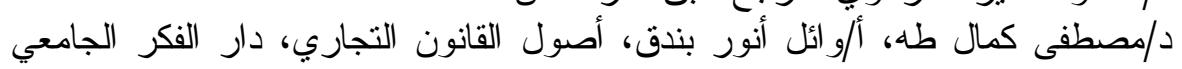

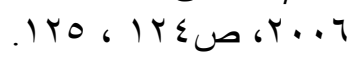


بالمحاكم الابتدائية لنظر المنازعات التجارية ودوائر أخرى لنظر المنازعات

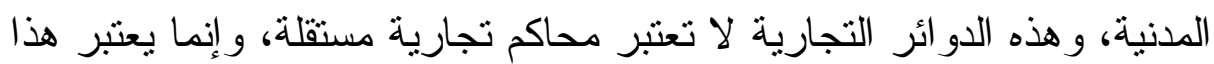

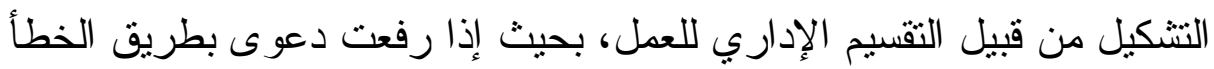

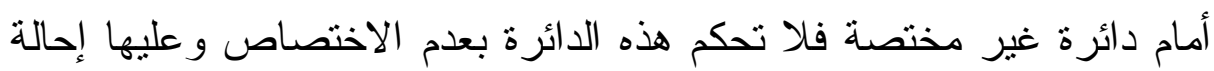

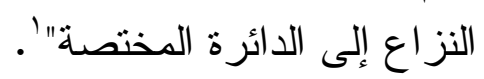

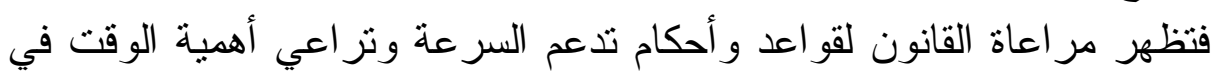

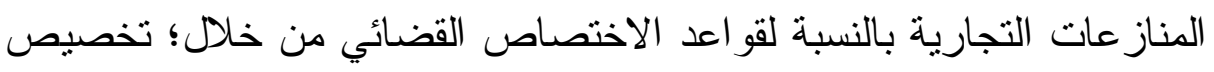

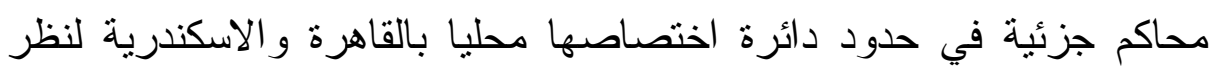

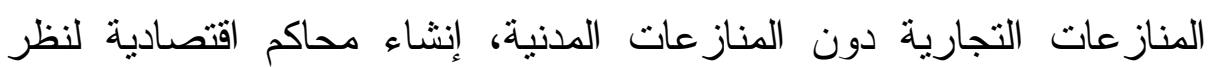
منازعات متعلقة بعدد من القوانين دون غير ها، فالسرعة تكمن في اختيار

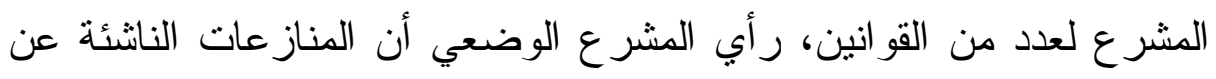

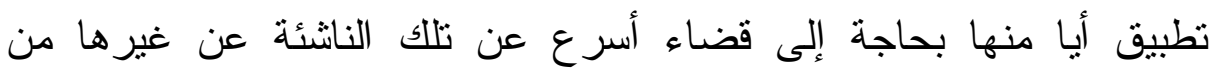

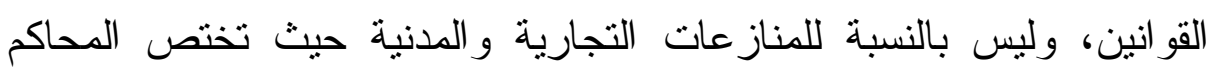

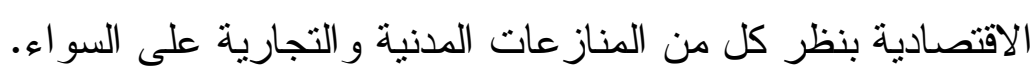

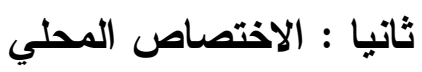
توسع القانون في تحديد المحكمة المختصة محليا بالنسبة للمنازعات المات التجارية

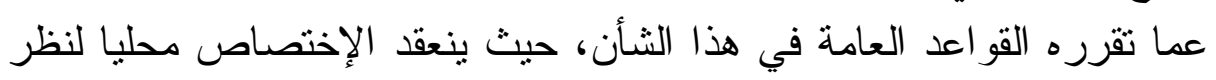

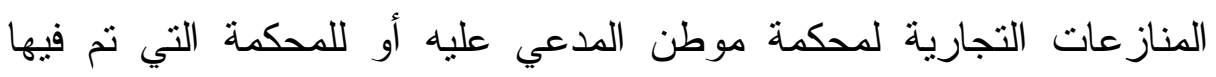

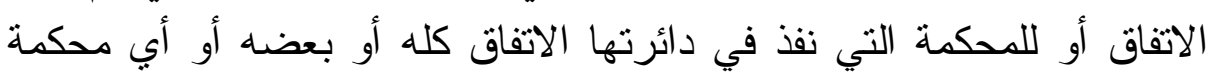

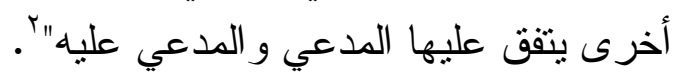

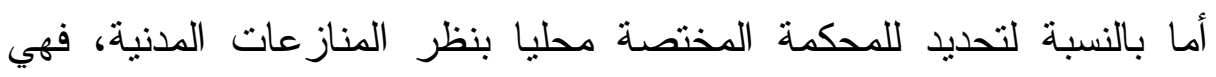

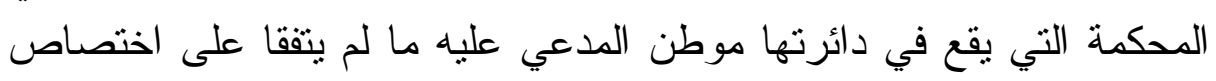

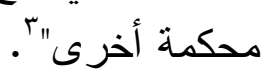
فالقانون أعطى للمدعي في المنازعة التجارية أربع خيارات لتحديد المحمة

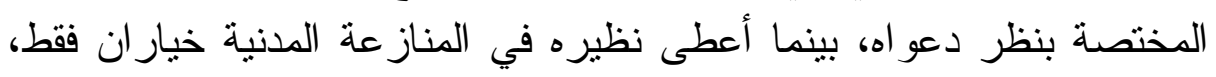

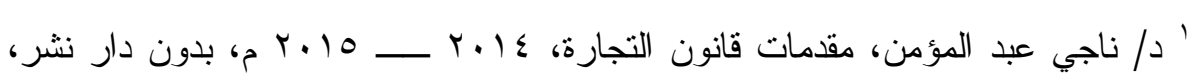

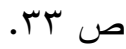

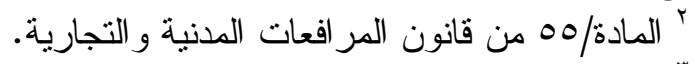

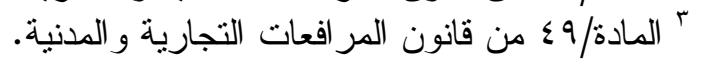


فهذا الحكم إن دل فإنما يدل على تحقيق وتدعيم أساس السرعة التي تتميز بها

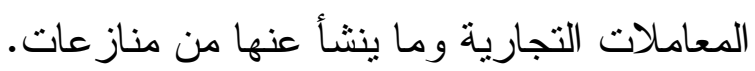

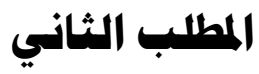 \\ القواعد الخاصة بالإثبات \\ أولا : الأصل في إثبات المسائل التجارية هو الحرية}

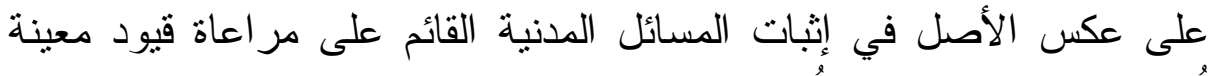
تحقق حماية المتعاقدين وتبصر هم بخطورة التصرفات التيات التي يقدمون عليها، فإن

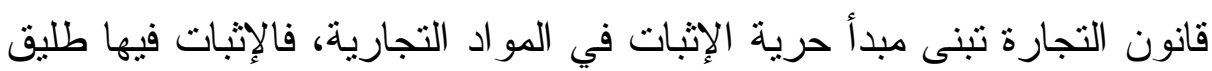

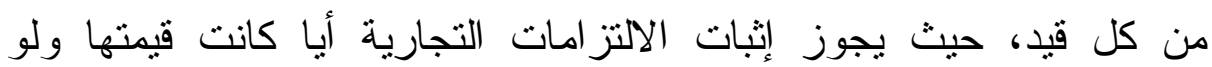
تجاوزت الألف جنيه بكافة طرق الإثبات من شهادة شهود وقر ائن

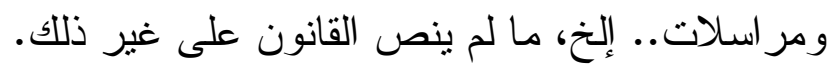

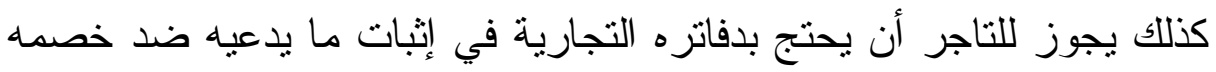

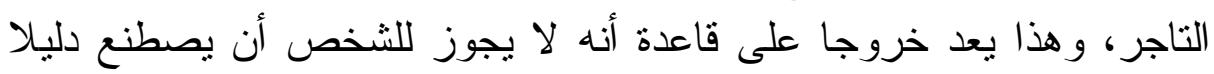

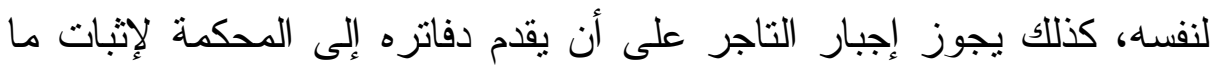

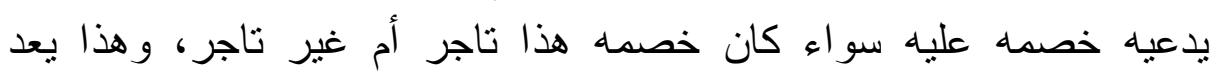

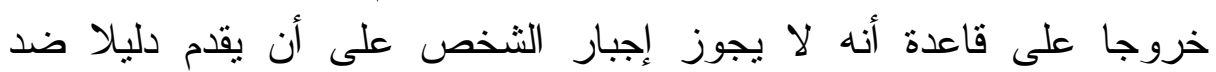
نفسه"'

ثانيا : الاستثناء هو مراعاة القيود التي ينص عليها القانون

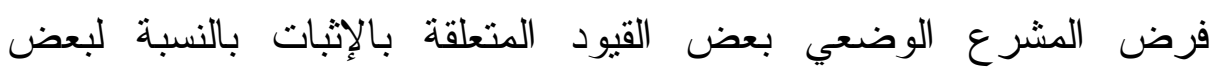

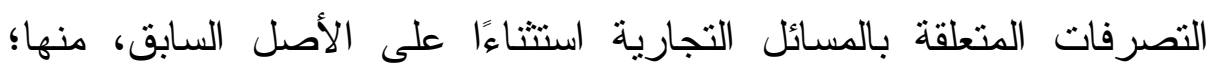

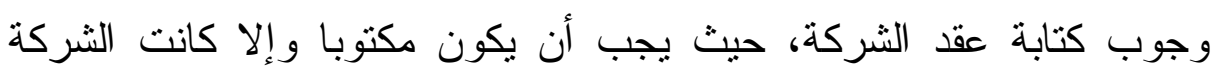
باطلة"r، وكل تصرف يكون موضوعه نقل ملكية المحل التجاري أو إنثاء

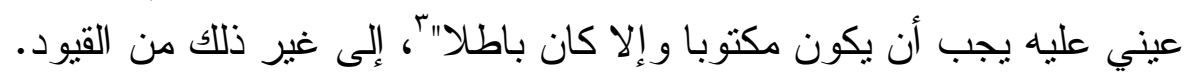

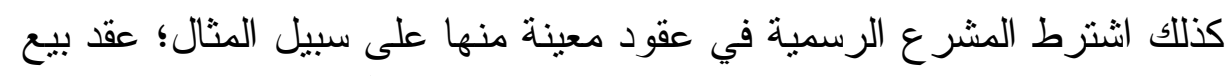

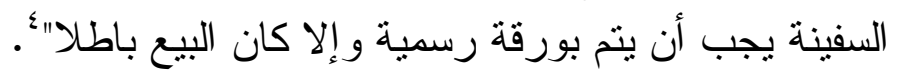

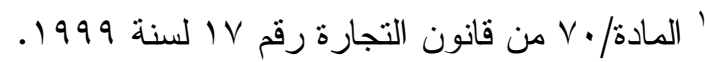

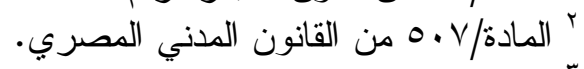

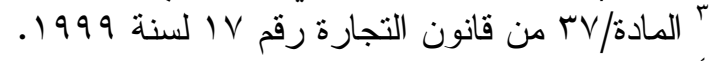

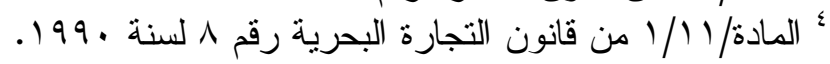


و البيّن مما سبق أن القو اعد التي وضعها المشرع الوضعي بخصوص الإثبات

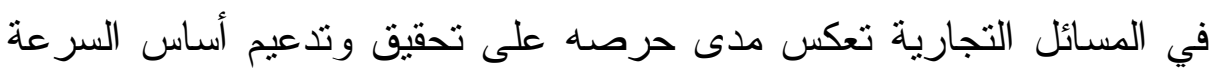

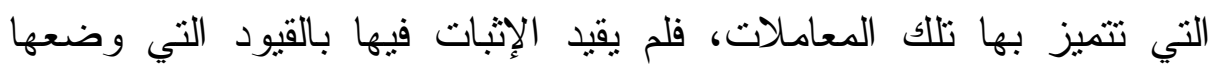

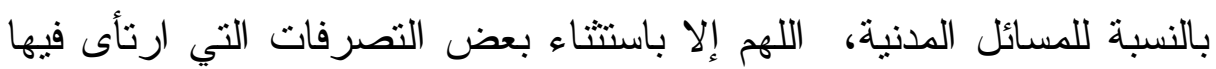

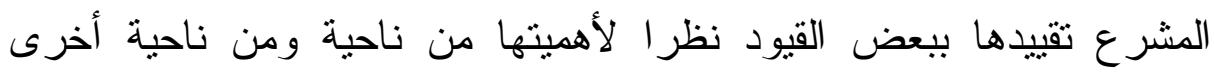

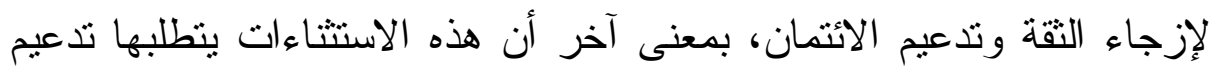

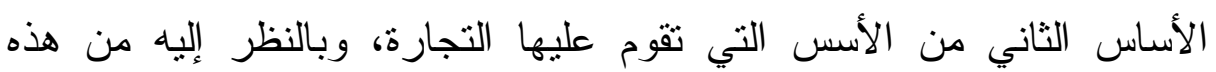
الز اوية يمكن القول أن هذه القيود لا تعتبر استثناء.

\section{الإطلب الثالث}

\section{بعض القواعد الخاصة بالالترزاهات التجارية التباه}

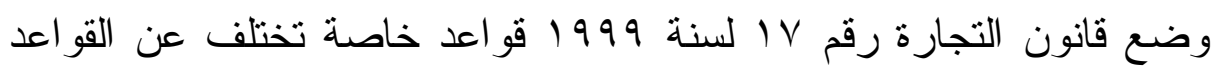
التي تخضع لها الالتزامات المدنية، وتهدف بعض هذأن هذه القو اعد إلى تدعيم

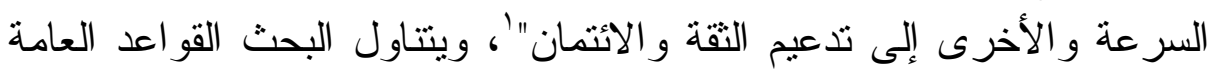

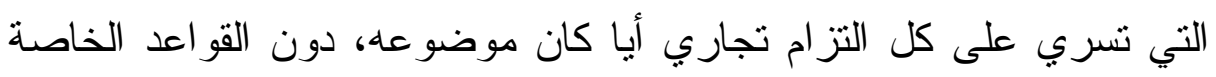

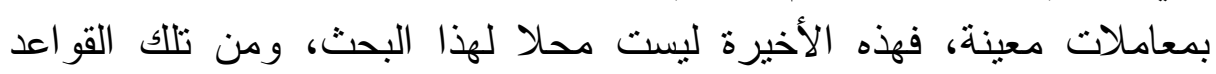

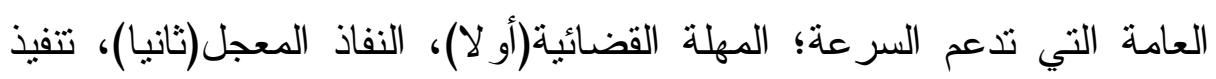
الر هن التجاري(ثالثا)، الإعذار (ر ابعا)، التقادم(خامسا). (أولا) : المهلة القضائية لا يجوز للقاضي أن يمنح المدين مهلة للوفاء بقيمة الورقة التجارية أو للقيام بأي إجر اء متعلق بها ما لم ينص القانون على غير ذلك وفي حدود ما يقرره

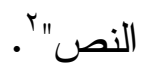

إذن المهلة القضائية محظورة في الأوراق التجارية، أما في غيرها من في التهان الالتزامات التجارية، فقد نتدد القانون في الثروط التي يستلزمها منح المهلة

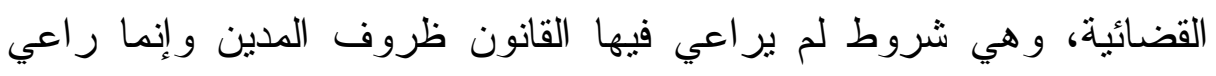

' سيقتصر الباحث هنا على بيان القو اعد التي تدعم السرعة، أما القو اعد الأخرى التي تدعم

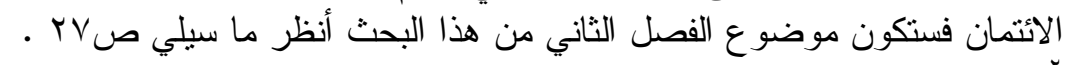

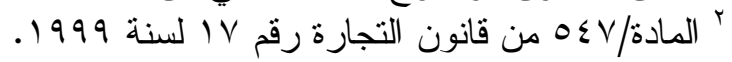


ظروف الدائن، حيث لا يجوز للمحكمة منح المدين بالتز ام تجاري مهلة للوفاء

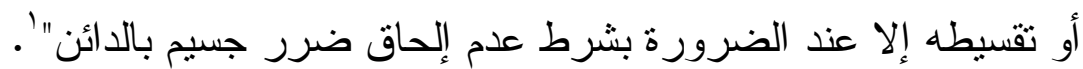

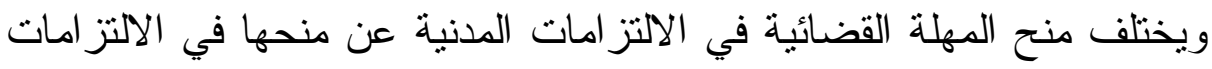
التجارية، حيث راعى القانون المدني حالة المدين المعسر عند منحها، شريطة

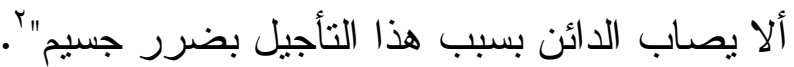

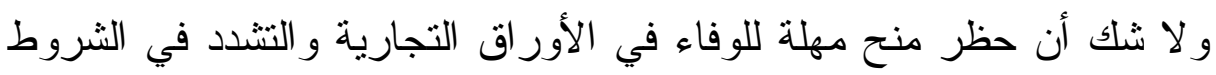

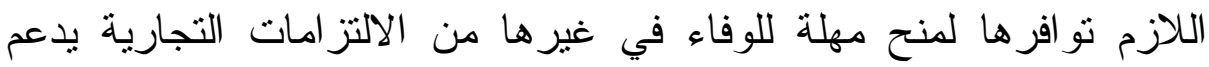

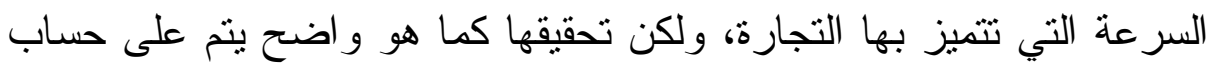
المدين المعسر بالرغم من أنه هو أولى بالرعاية من الدائن الذي رلئ راعي القانون

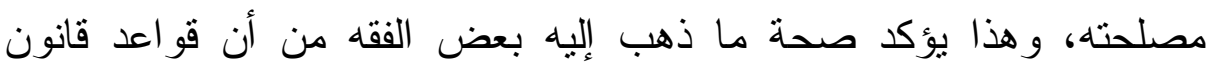

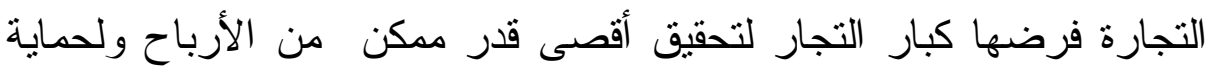

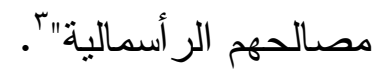

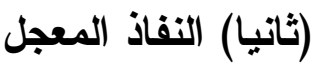

الأصل أن الأحكام القضائية لا يجوز تتفيذها إلا إذا أصبحت نهائية أي لا تقبل

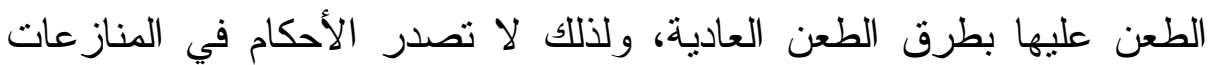
المدنية مشمولة بالنفاذ المعجل إلا في حالات استثنائية وردت على سبيل

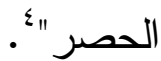
أما بالنسبة للأحكام الصادرة في المواد التجارية فهي مشمولة بالنفاذ المعجل

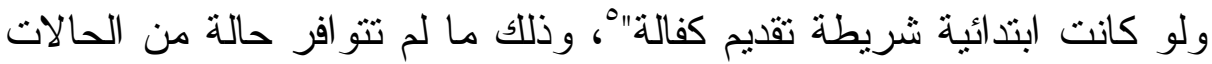

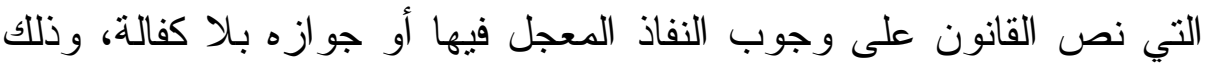
نظر الما نقتضيه المعاملات التجارية من سر عة في اقتضاء الحقوق.

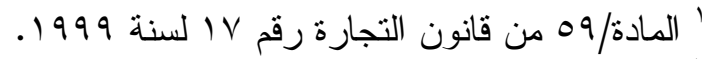

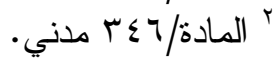

${ }^{3}$ Gerard Lyon-caen : conirtbution a la recherche d'une definition du droit Commercial.

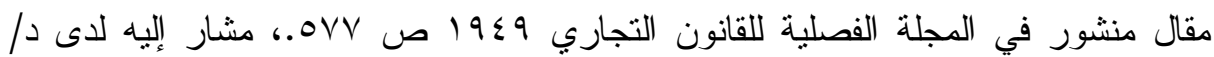

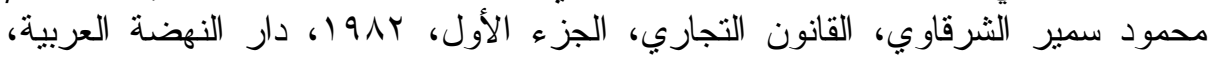




\section{(ثالثا) تنفيذ الرهن التجاري}

يخضع الرهن المعقود ضمانا لدين تجاري في تتفيذه لإجر اءات خاصة بسيطة، إنهاء

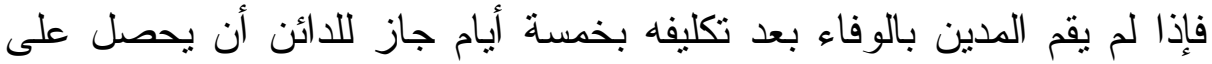

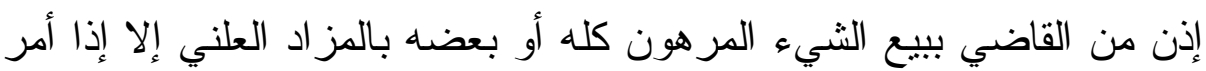

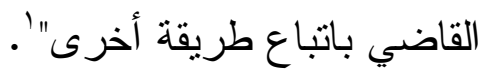

فلا يلزم الدائن بالحصول على حكم كما هو الحال في الرهن المدني، وذللك

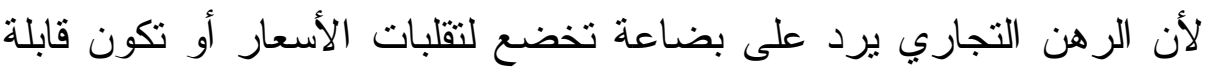
للتلف، و إذا لزم الحصول على حكم فيخشى من انخفاض الأسعار خلال فترة التقاضي أو تلف البضاعة فلا يستوفي الدائن كامل حقه. ولذلك خضع الرهن التجاري لقواعد خاصة تسمح بسرعة تتفيذ الرهن

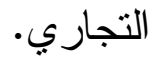

$$
\text { (رابعا) الإعذار (لمار }
$$

يثبت الإخلال بالالتزامات العقدية وفقا للقو اعد العامة بعد أن يقوم الدائن

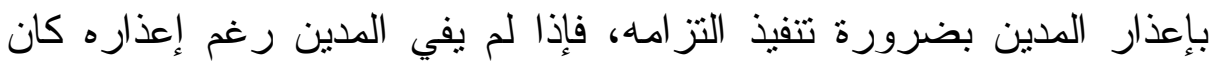

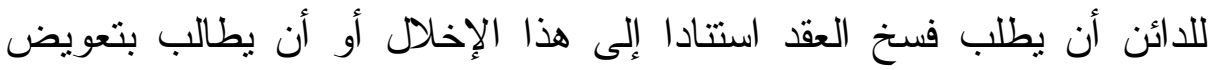

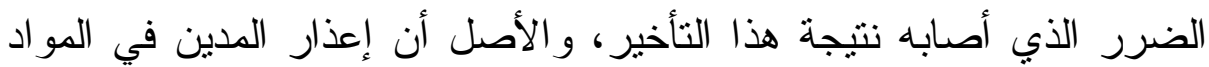
المدنية يكون بإنذاره، أي بمطالبته بالوفاء بمقتضى ورقة رسمية تعلن وإيه إليه

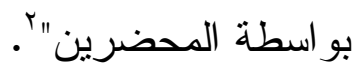
أما في المسائل التجارية وتدعيما للسرعة التي تتسم بها، فقد استقر العرف التجاري منذ زمن بعيد على جواز أن يتم الإعذار في المسائل التجارية

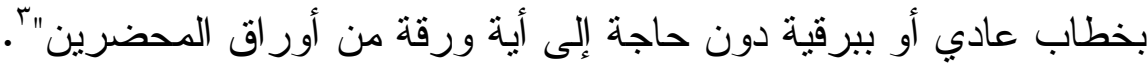

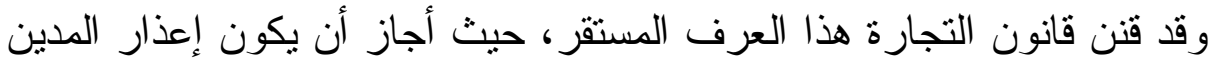
في المواد التجارية بإنذار رسمي.... ويجوز في أحوان ال الاستعجال أن يكون الإعذار ببرقية أو تلكس أو فاكس أو غير ذلك من وسائل الاتصال الحديثة" فئ.

$$
\begin{aligned}
& \text { ' ' المادة/צr/ 1 من قانون التجارة. }
\end{aligned}
$$

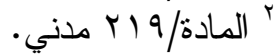

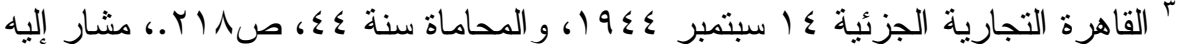

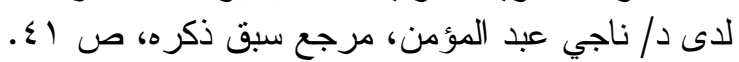

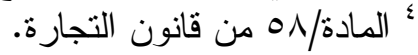


كان التقادم المسقط للحقوق في المسائل التجارية في ظل التقنين التجاري

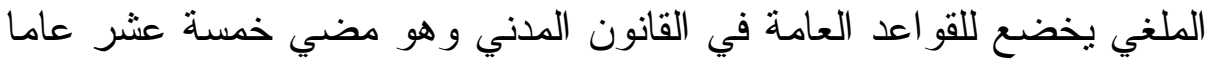

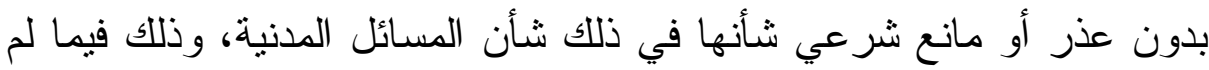

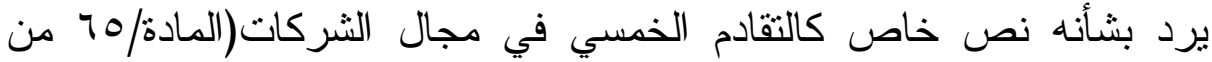
التقنين التجاري الملغي).

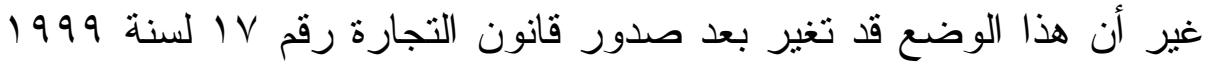

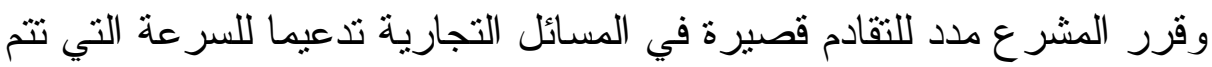
بها هذه المعاملات، ومن هذه المدد ما يلي :

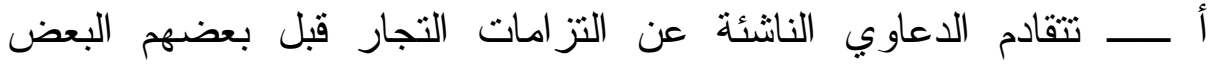
و المتعلقة بمعاملاتهم التجارية بمضي سبع سنين من تاريخ حلول ميعاد الوفاء

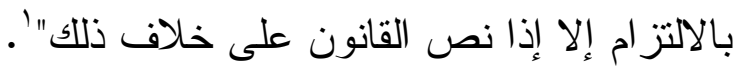
ب - بـ وبالفعل نص القانون على غير مدة السبع سنين المذكورة في البند

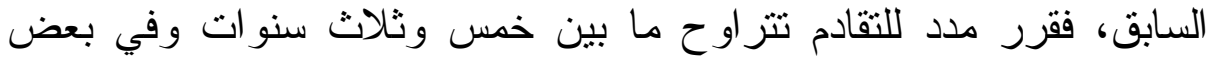

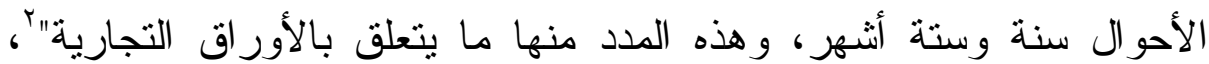

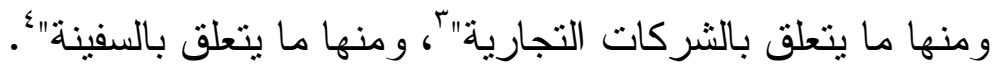

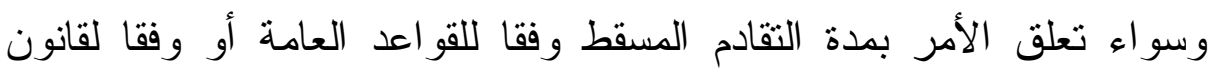
التجارة بمدده القصيرة تدعيما للسرعة، فإن هذه القدة القواعد تعكس كيف أن

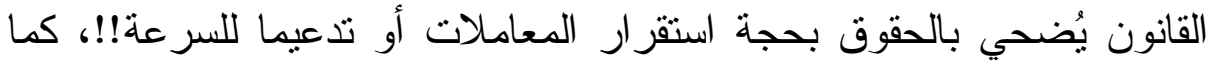
أن هذه القو اعد المنظمة للتقادم_تؤثر بالسلب على الدعامة الثانثة الثانية التي تقوم

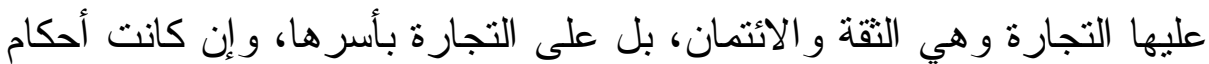
وقف مدد التقادم و انقطاعها تقلل من هذه المخاوف و السلبيات.

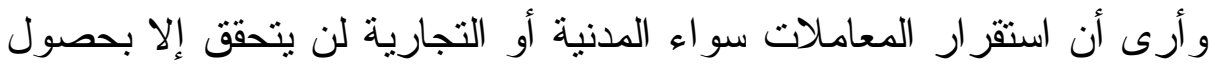

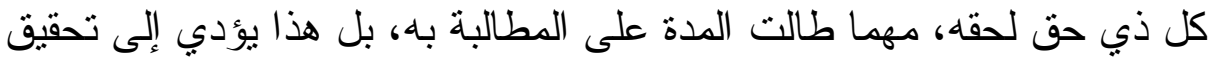
الأمن و السلم الاجتماعي في البلاد، وهذا ما حرصت عليه أحكام الشريعة

$$
\begin{aligned}
& \text { ' المادة/1 7 من قانون التجارة. }
\end{aligned}
$$

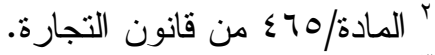

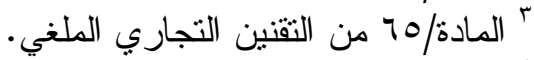

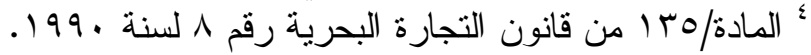


الإسلامية الغر اء، فالحق لا يسقط إلا بالأداء أو بالإبر اء لعموم قول الله تعالى "

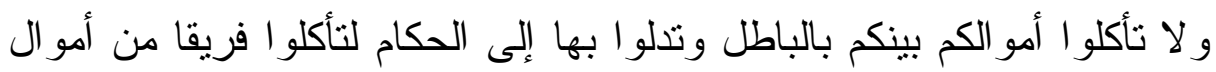

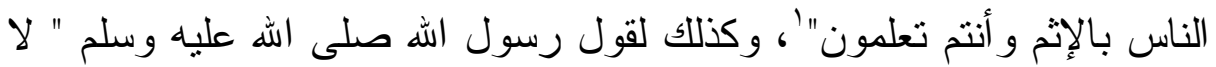

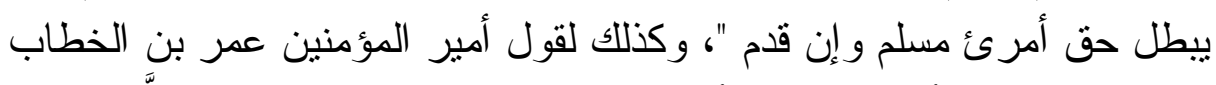

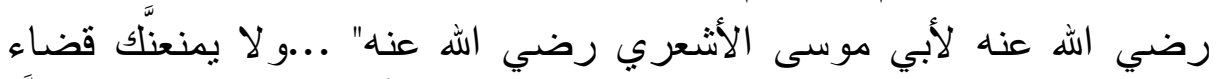

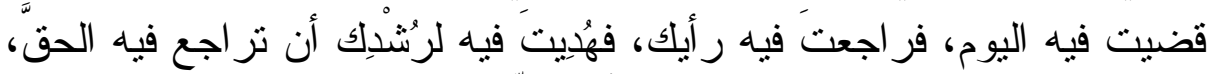

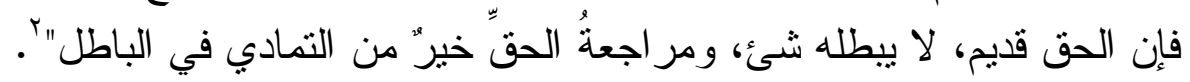

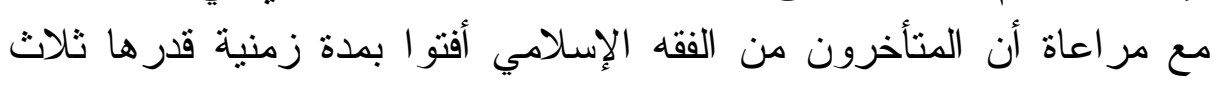

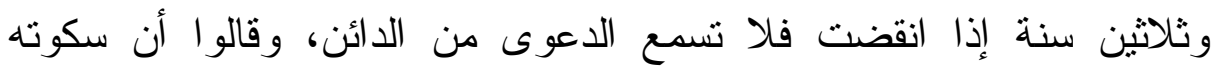

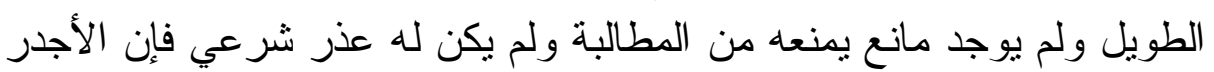

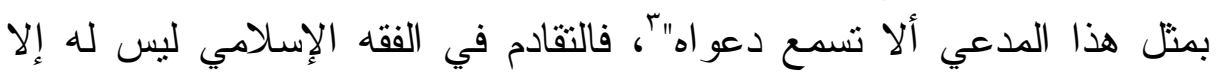
معنى و احد وهو عدم سماع الدعوى بالحق وليس قضاء بسقوط الحق بمضي لهي السنين، كما يقول بن نجيم في البحر الرائق " من القضاء الباطل القيل القضاء

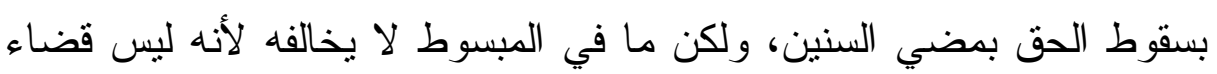

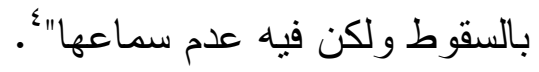

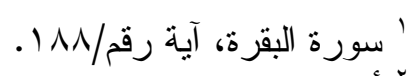

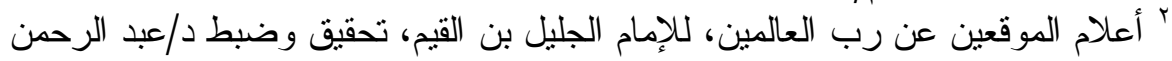

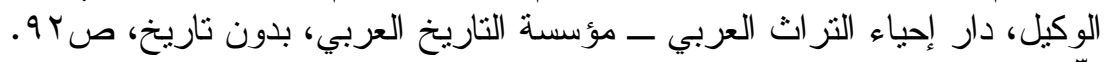

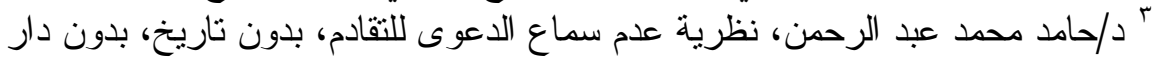

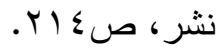

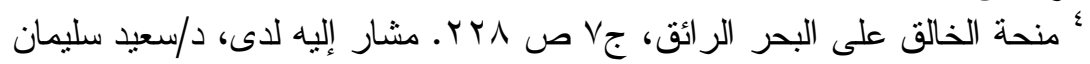

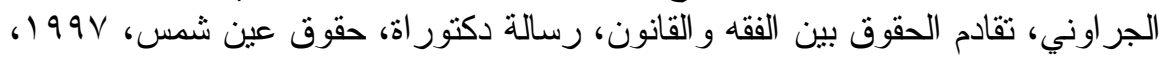

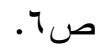




\section{المبحث الثاني \\ بعض القواعد التي تراعي أهسية الوقت في المعاميلات

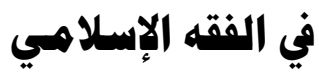

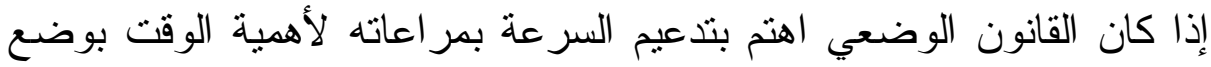
قو اعد وأحكام تحقق ذللك، فإن تتظيم الإسلام للمعاملات في السوق للأفر اد لاد

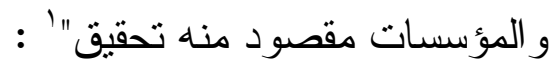

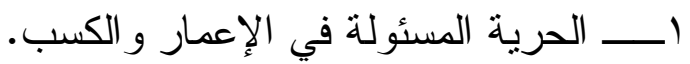
r إقـامة العدل في السوق وتوزيع الدخل.

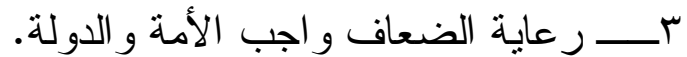

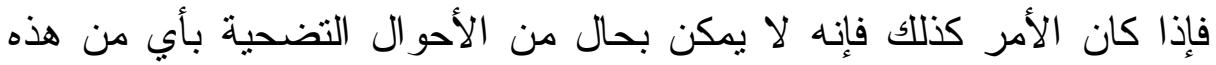

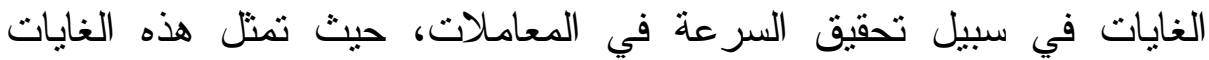
الضوابط الحاكمة عند وضع قو اعد تدعم السرعة بمر اعاة أهمية الوقت في الثريعة الإسلامية.

و إذا كانت الثريعة الإسلامية لم تفرق بين التاجر وغير التاجر ولا بين

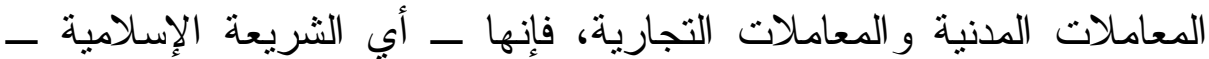

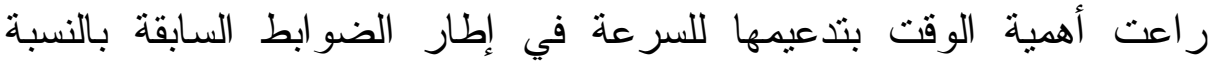

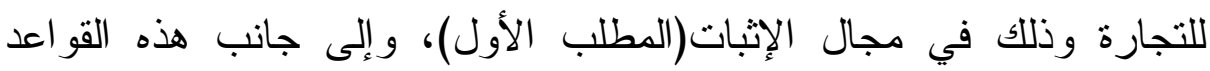

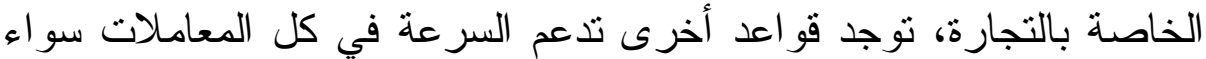
كانت مدنية أو تجارية(المطلب الثاني)

\section{الامطاب الأول}

\section{القواعد التي تراعي أهمية الوقت في المعاملات التجارية}

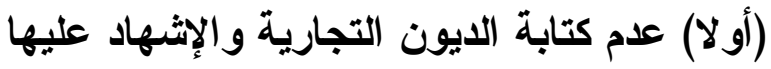

نزلت أطول آية في القرآن - آية المداينة - لتأمر بكتابة الدين والإيهاد الإشهاد عليه صيانة للأمو ال وقطعا للمنازعة وللتحرز من العقود الفاسدة ورفعا للارتياب

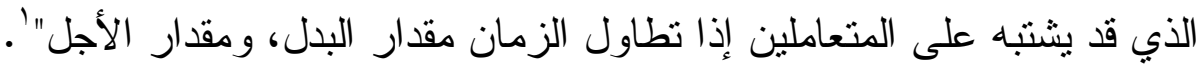

' أزيوسف كمال محمد، فقه اقتصاد السوق " النشاط الخاص"، بدون تاريخ، بدون دار

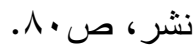


وفي ذات الآية تسومح عن هذا الإجراء بالنسبة للتجارة، نظر الما تتطلبه

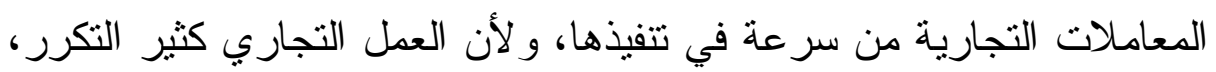

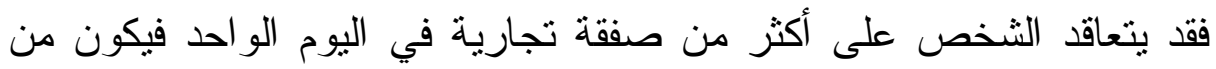

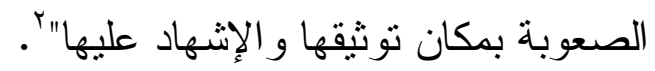

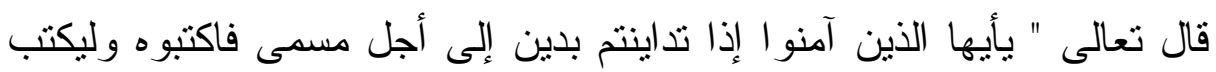

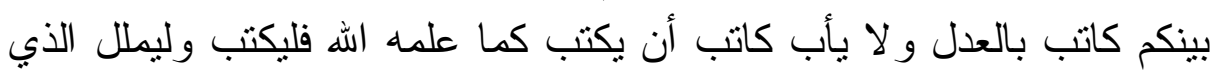

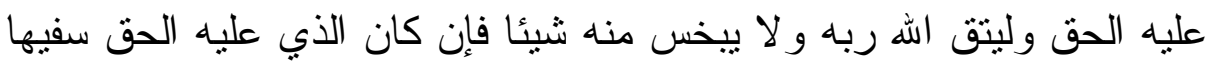

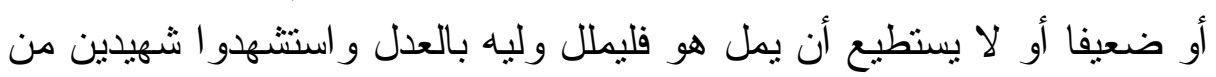

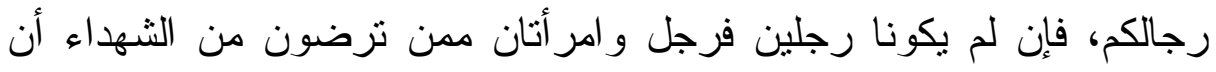

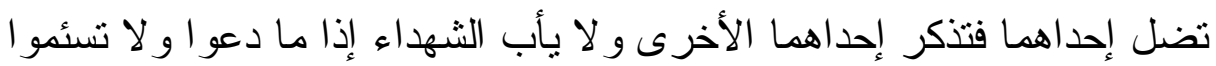

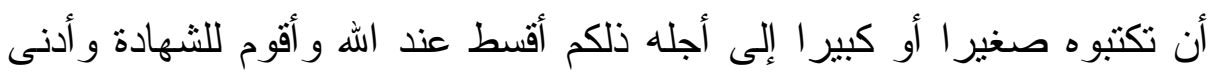

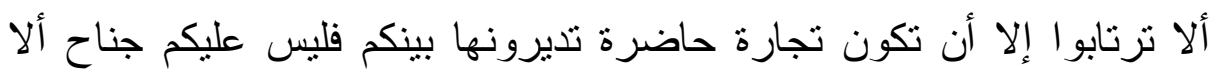

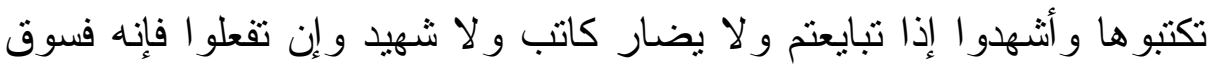

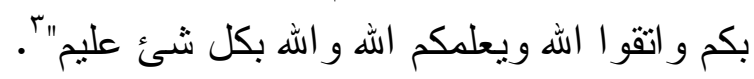

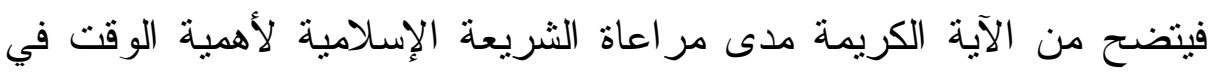

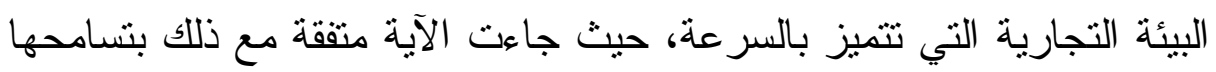
عن كتابة الديون التجارية و الإشهاد عليها.

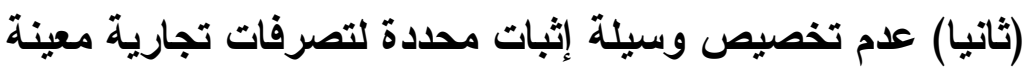

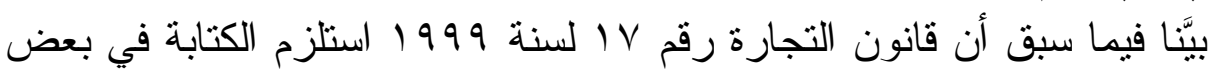

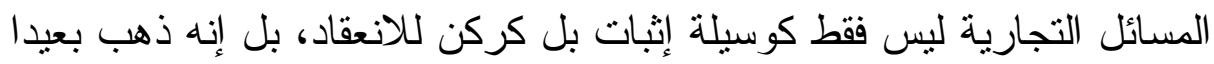

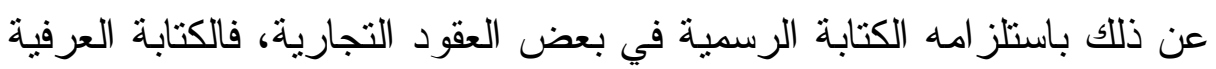

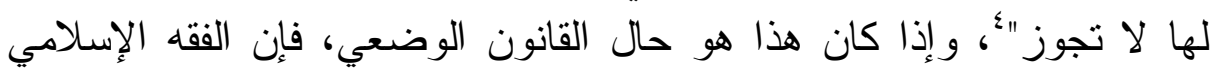

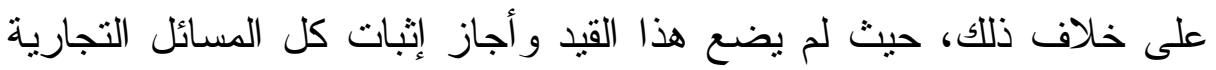

'د/صبري مصطفى حسن السبك، القرض المصرفي كصورة من صور الايتمان و أداة

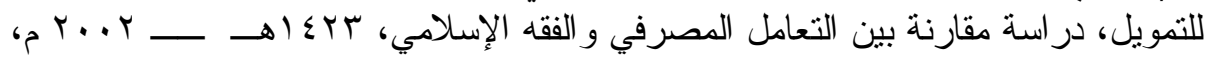

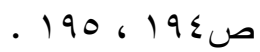

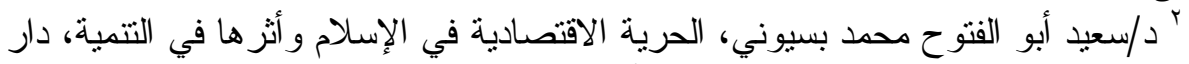

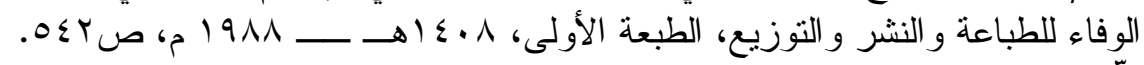

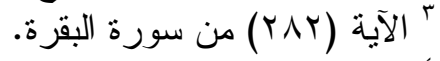

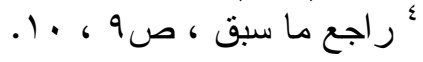


بالكتابة أو بالثهادة أو بهما معا"'، فهذا الحكم يدل على مدى مر اعاة الفقه

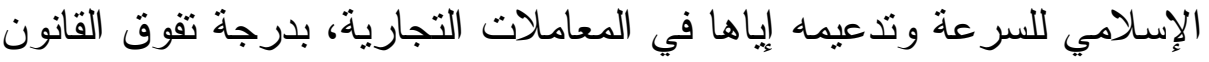

$$
\text { الوضعي في هذا الخصوص. }
$$

\section{الإطلب الثاني \\ بعض القواعد التي تراعي أهـية الوقية الوقت في المعاهلات

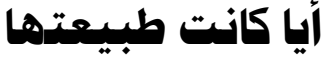

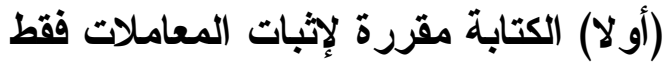

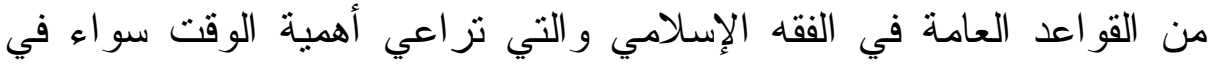

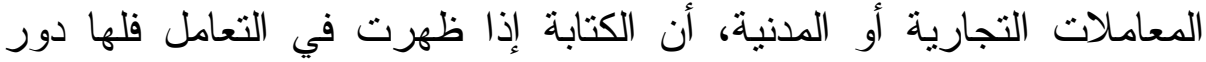

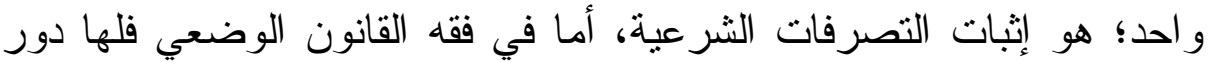

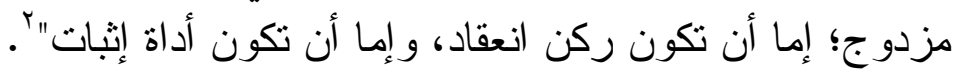

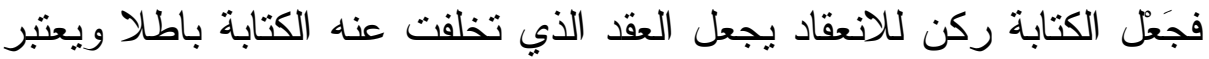

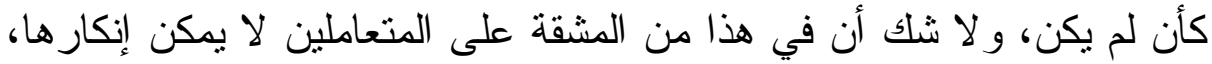

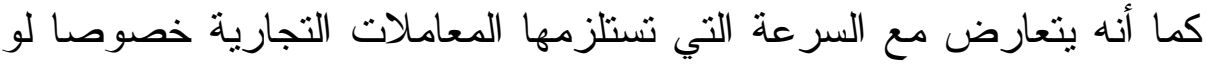
كانت الكتابة المطلوبة هي الكتابة الرسمية.

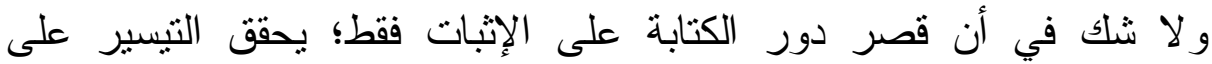

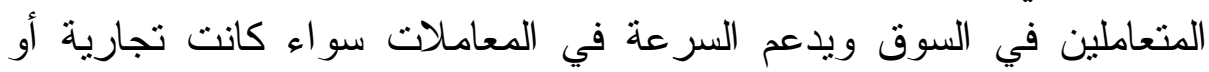

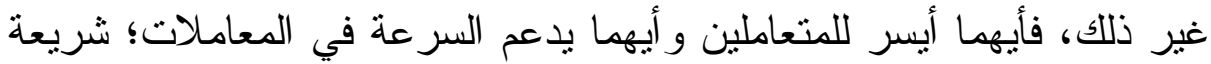

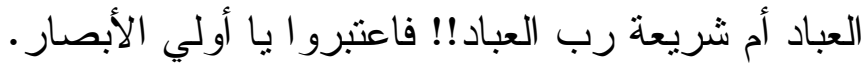
(ثانيا) السماحة في التعامل

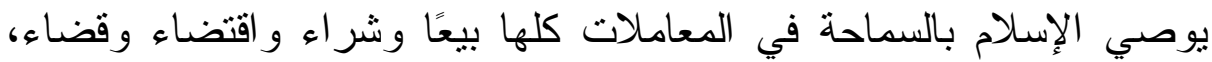
عن جابر بن عبد الله رضي الله عنهما، أن رسول الله صلى الله عليه وسلم قال

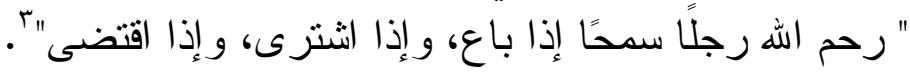
وقد بوب البخاري - رحمه الله - لهذا الحديث بقوله ( باب السهولة والة والسماحة في الثراء و البيع ومن طلب حقًا فليطلبه في عفاف )"ئ، فهذا الخلق الكريم

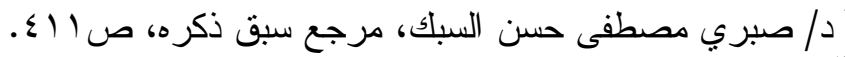

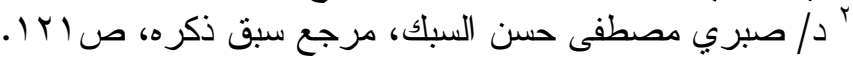

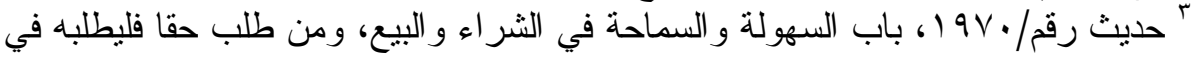

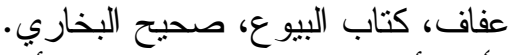

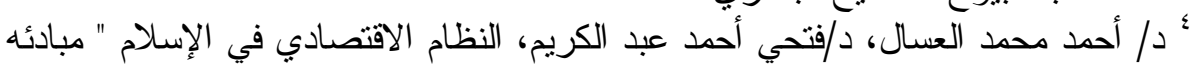

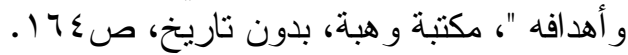


يؤدي إلى السهولة في التعامل بين المتعاملين على نحو ما ذكر الإمام البخاري رحمه الله.

ومن نتائج السهولة؛ إبر ام العقود بسرعة دون تسويف و لا حلف، وهذا ما أكد

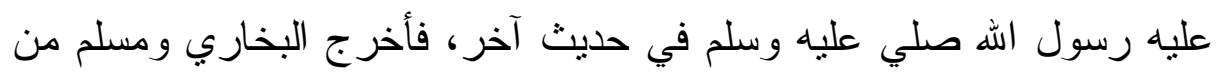
حديث أبي هريرة رضي الله عنه قال : سمعت رسول الله صلى الله عليه وسلم

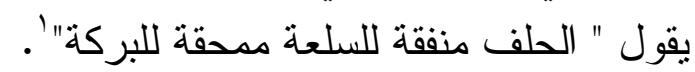

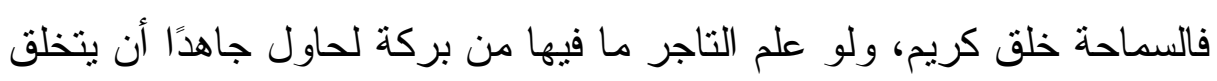

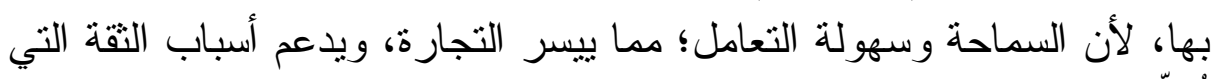

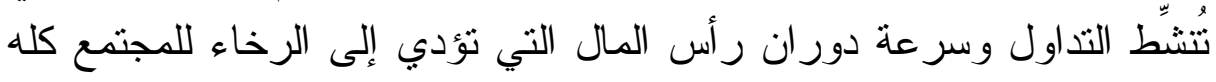

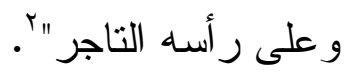

(ثالثا) اختلاف مفهوم الربح في الإسلام عن غيره من النظم الوضعية

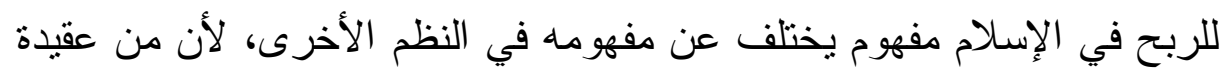

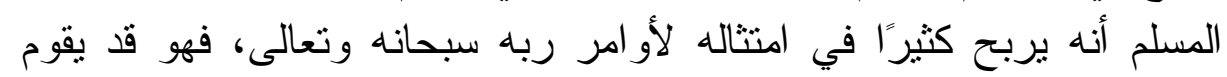

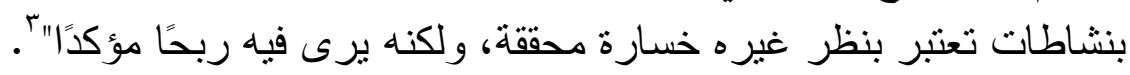
ومن أجل ذلك فإن الهدف من التعامل ليس انطلاق الناس في تحقيق مصالحهم

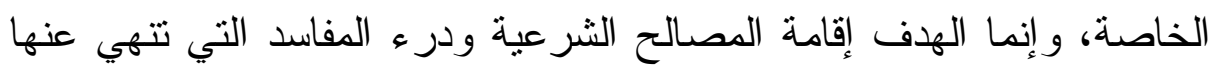

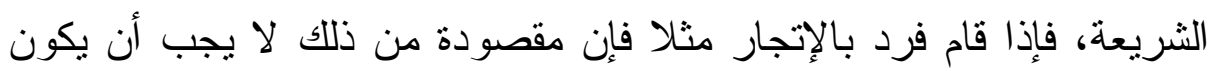

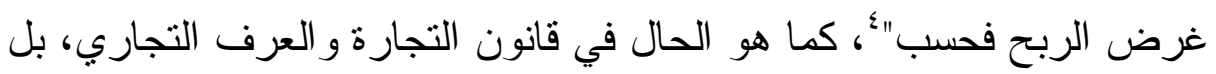

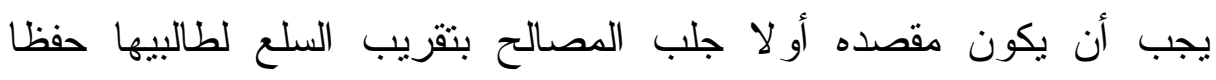

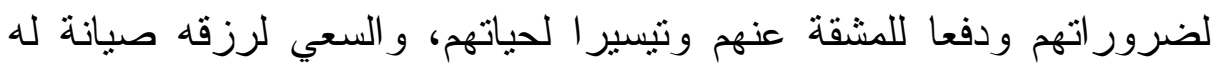
وحفظا لأسرته. فالتاجر بتجارته يحقق قصد عام وقصد خاص، و الأول مقدم على الثاني،

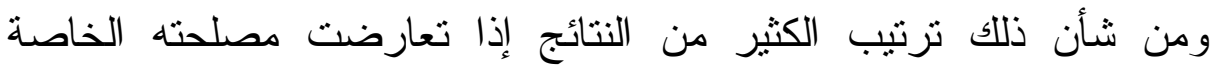

' حديث رقم/1911، باب يمحق اله الربا ويربي الصدقات و الهه لا يحب كل كفار أثثي،

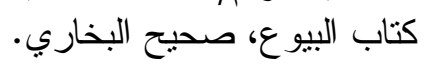

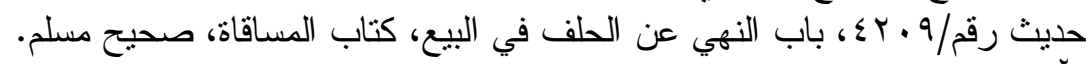

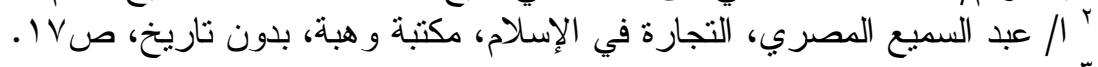

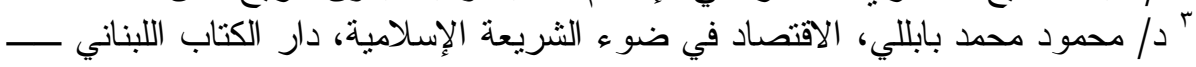

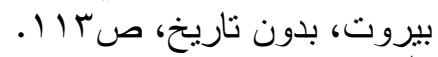

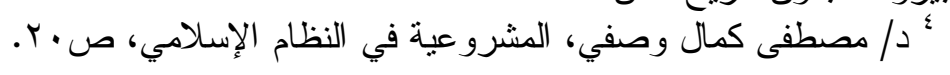


و المصلحة العامة، كذلك من شأنه أن يبرز العنصر الأخلاقي في المعاملات

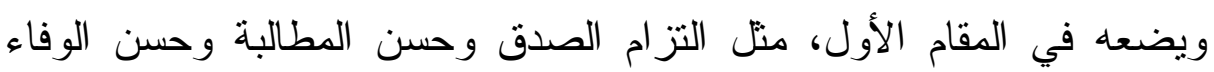

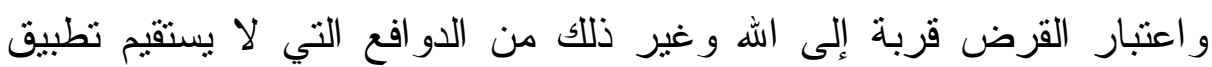

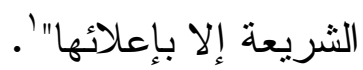
ولا شك أن من نتائج هذا المفهوم للربح في الإسلام تحقيق وتدعيم السرعة في

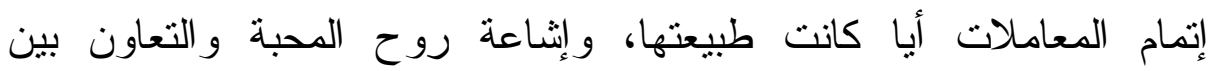
المتعاملين في السوق.

\section{المبحث الثالث}

\section{هقارنة بين الفقه الإسلاهي والقانون الوضهي}

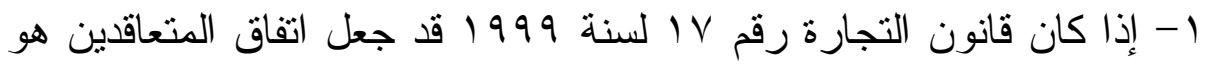
المصدر الأول لتتظيم المعاملات بين المتعاملين الخاضعين له لتدعيم وتحقيق

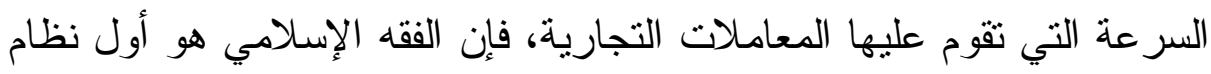

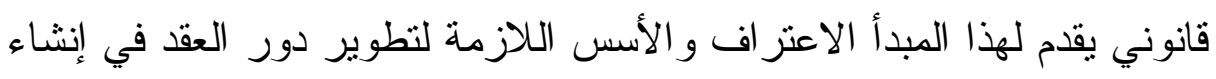
الالتز امات في المجتمعات الإنسانية"، فقد اعترف الفقهاء المسلمون للعقد بدور

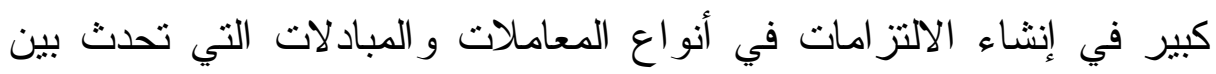

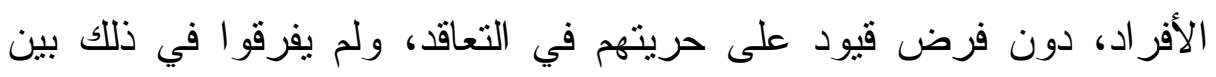

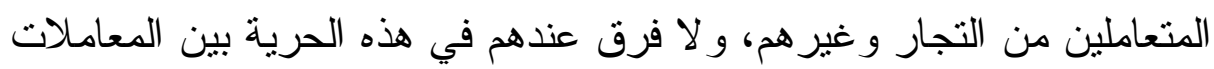

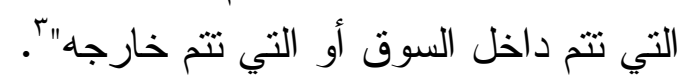

r- إذا كان قانون التجارة قيد اتفاق المتعاقدين بألا يخالف النظام العام في لفاري

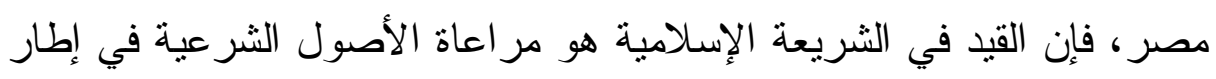

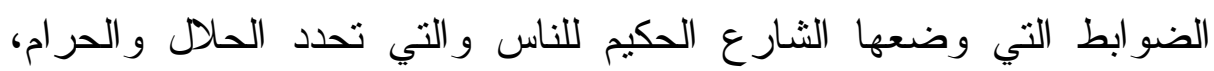

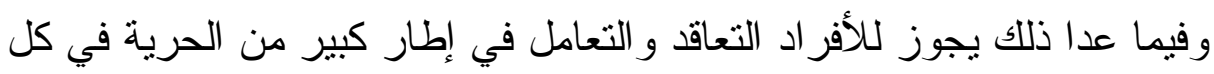

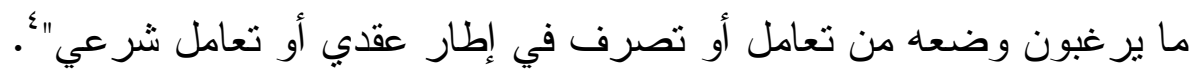

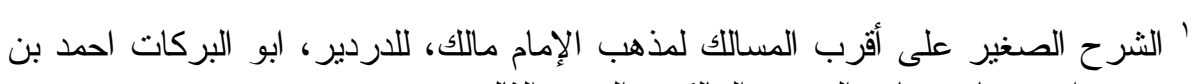

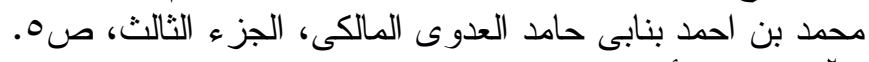

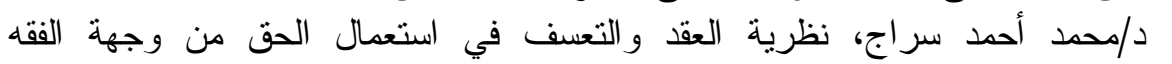

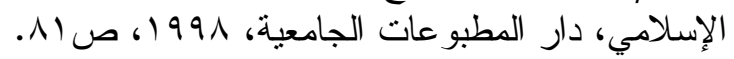

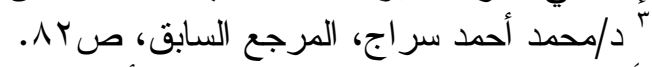

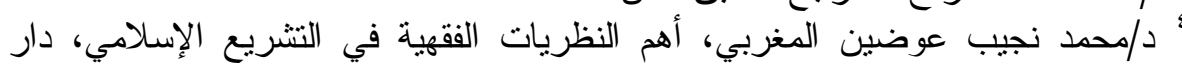

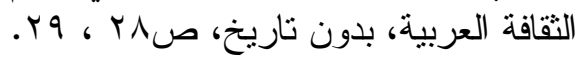




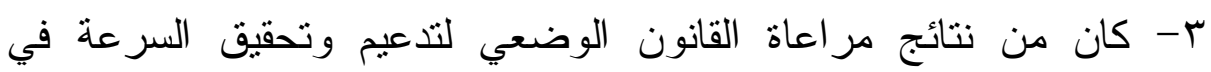

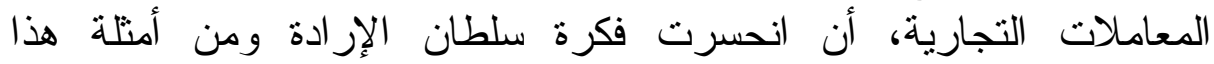
الانحسار : أ - التعامل بالعقود النمطية أو النموذجية المكتوبة التي لا يمارس الأفر اد عند

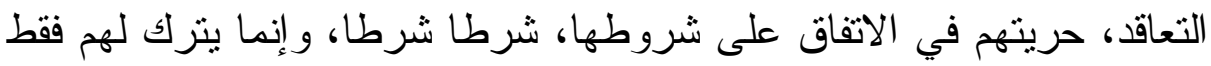

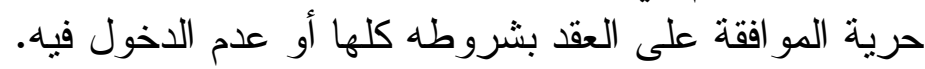

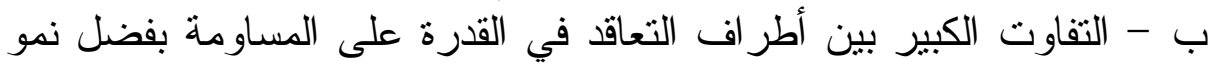
الاحتكار ات بين الكيانات الاقتصادية الضخمة.

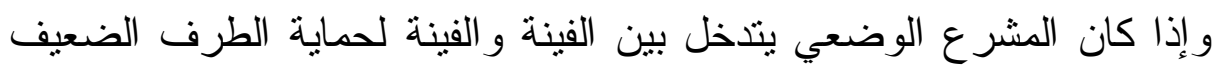

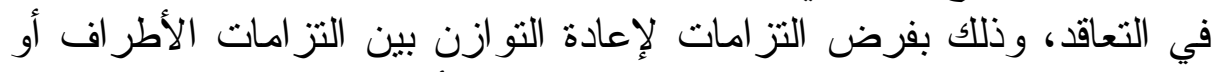

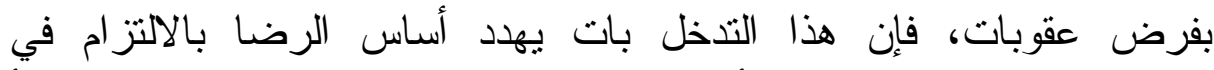

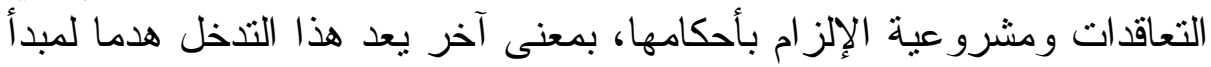
سلطان الإز ادة القائم عليه اتفاق الإن المتعاقدين.

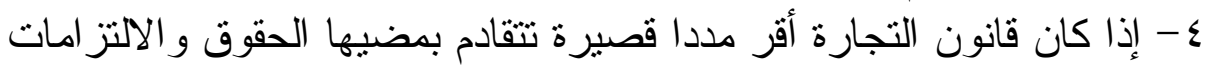

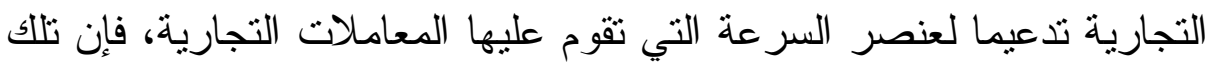
الفكرة - أي فكرة التقادم كسبب لانقضاء الحقوق و الالتز امات - نبذها الفقانه

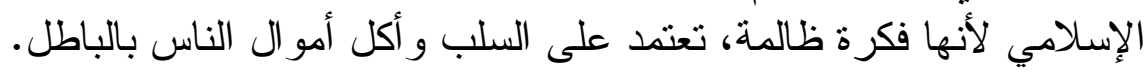

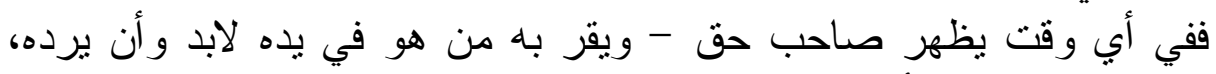

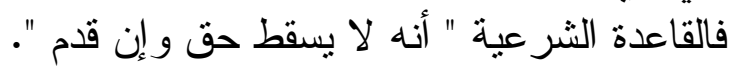

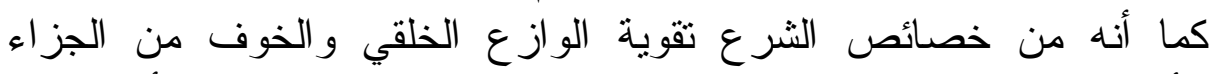

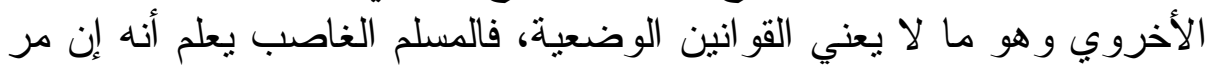

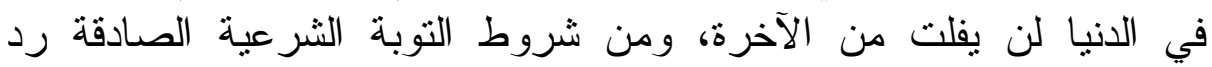

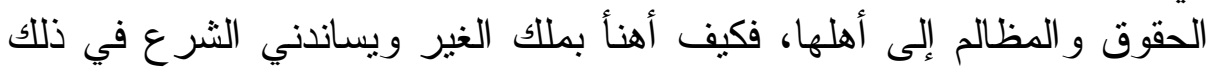

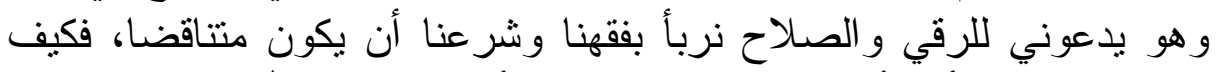

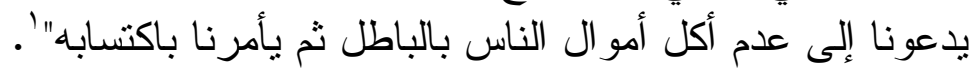

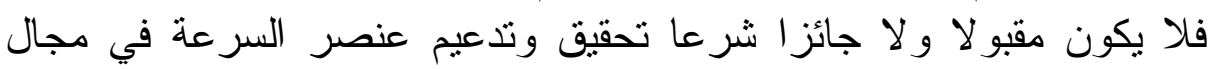

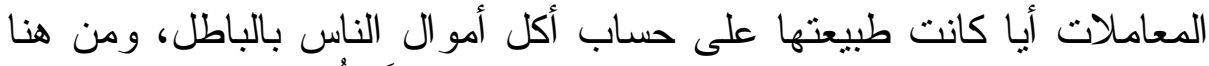

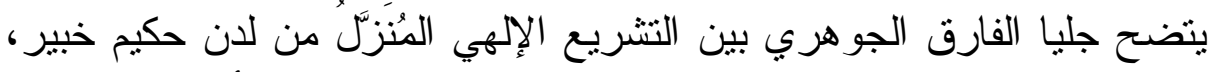
وبين التشريع الوضعي العاجز بعجز و اضعه عن تحقيق هذه الأهداف السامية.

' د/محمد نجيب عوضين المغربي، أهم النظريات الفقهية في التشريع الإسلامي، دار الثقافة

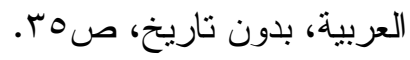




\section{النصل الثاني \\ الائتمان في الفقه الإسلاهي والقانهون الوضعي الوضي}

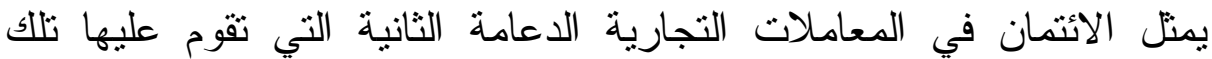

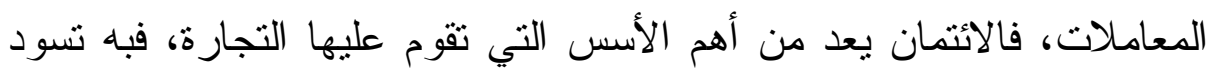

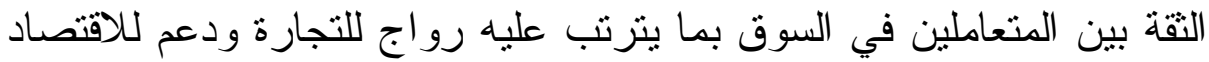

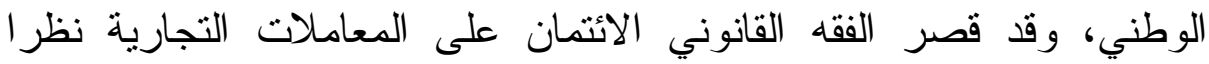
لتقرقته بين المعاملات التجارية و المعاملات المدنية، بينما الفقه الإسلامي جعل العان

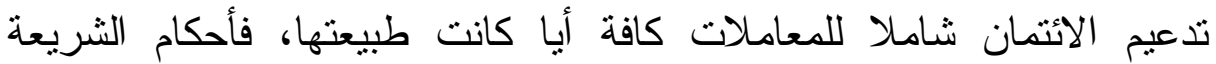

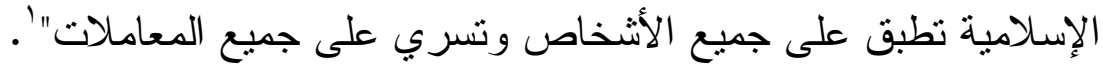

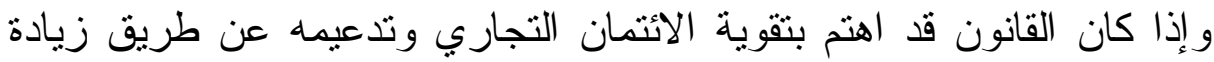

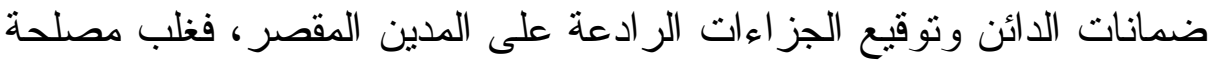

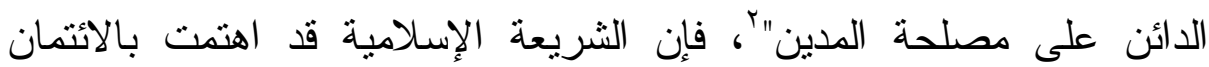

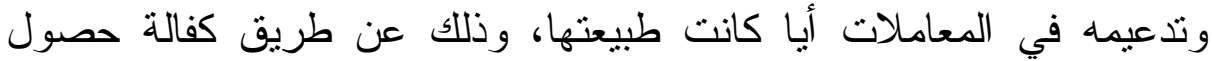

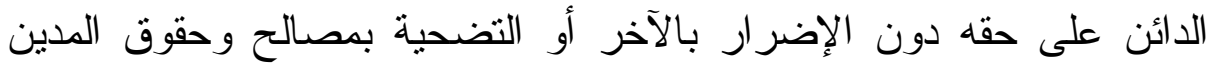

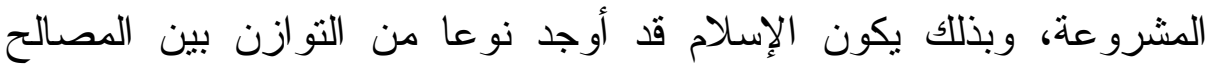
المتعارضة فلا يمكن تحقيق الائتمان أو تدعيمه في المعاملات بالتضحية

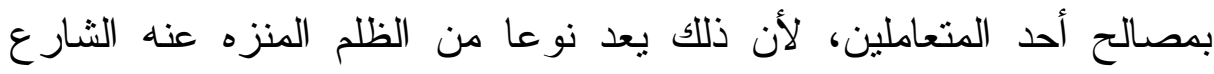

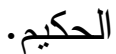

وسأتتاول هذا الفصل في مباحث؛ (المبحث الأول) أخصصه للائتمان في

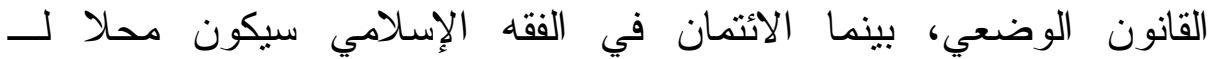

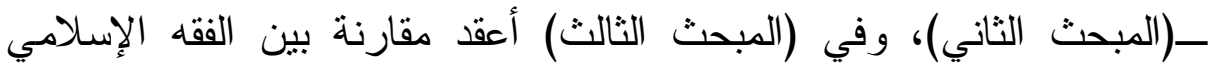
و القانون الوضعي في هذا الصدد تؤكد ما سبق إجماله آنفا.

' دم/ محمود سمير الثرقاوي، القانون التجاري " الجزء الأول " ، دار النهضة العربية، (

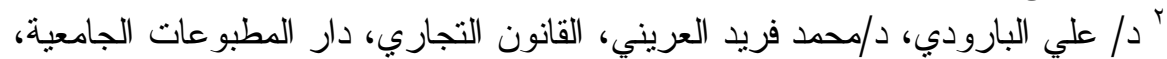

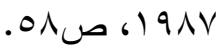




\section{المبحث الأول}

\section{القواعد التي تهقق الائتمان في المعاهلات التجارية في القانون الوضعي}

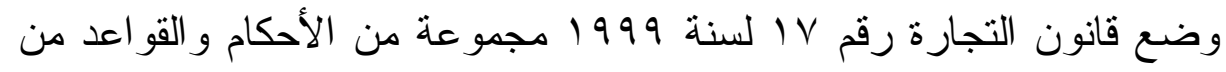

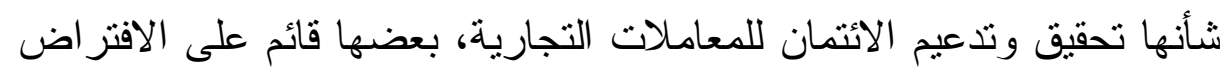

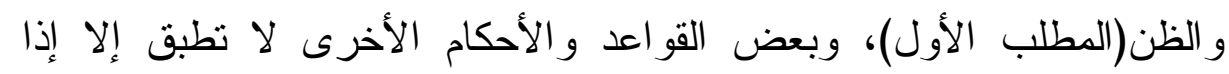
تحقت شروطها المنصوص عليها في القانون(المطلب الثاني).

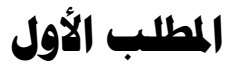 \\ القواعد الاقننة على الافتزاض والظن الاولن}

(أولا) افتر اض التضامن

التضامن في المسائل التجارية مفترض بمفتصنى العنى العرف التجاري بين المدينين

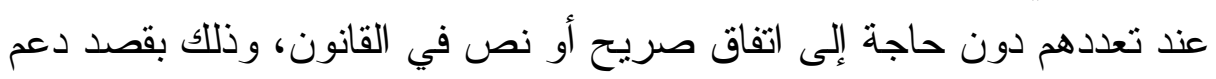

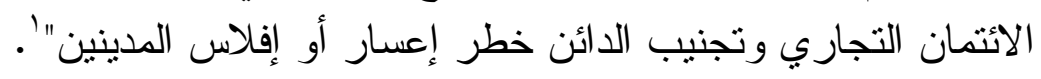

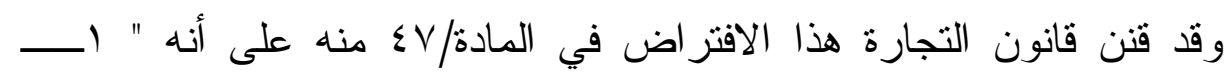

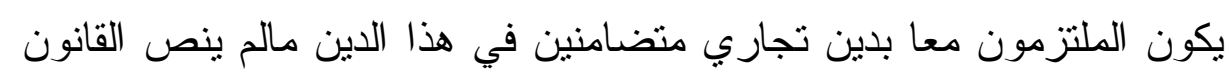

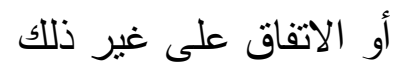

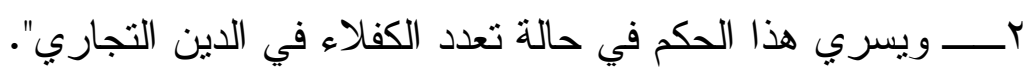

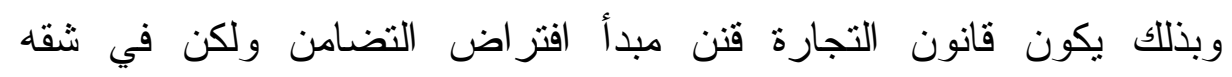

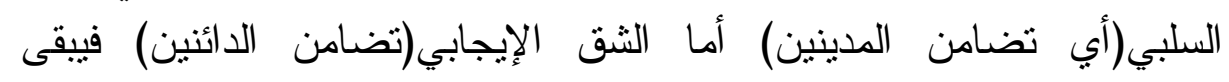
مفترضا بمقتضى العرف التجاري.

و إذا كان القانون ينص على التضامن بلى في في بعض الحالات كما هو الحال بالنسبة

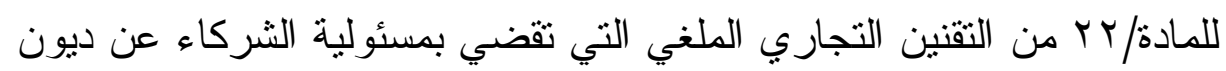

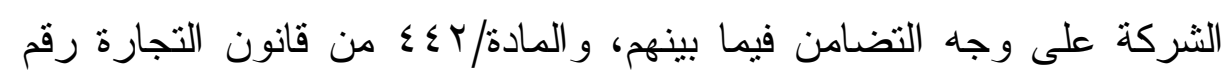

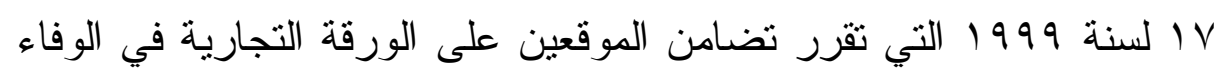

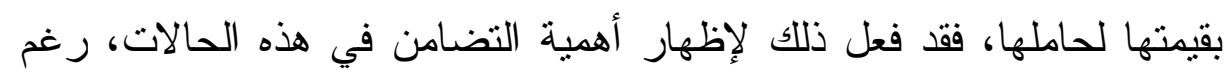

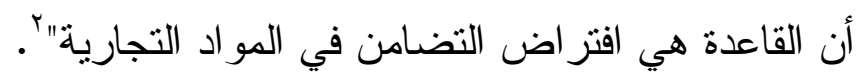

' د/مصطفى كمال طه، أ/و ائل أنور بندق، أصول القانون التجاري، دار الفكر الجامعي،

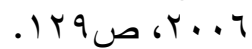

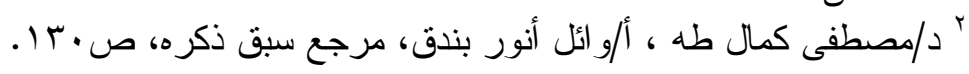


فالتضامن بهيئ ائتمانا قويا، وذلك بزيادة فرص حصول الدائن على الدين كله

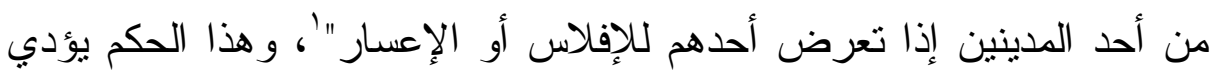

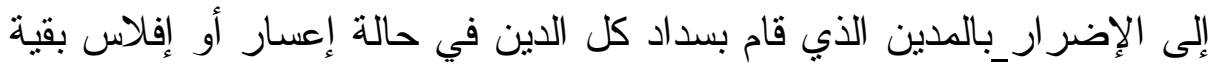

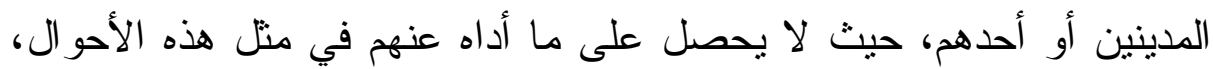

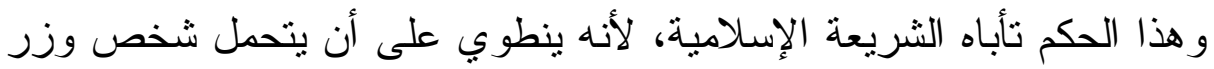

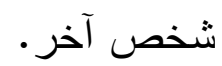

\section{(ثتانيا) افتر اض اضر • المقابل}

افترض القانون أن أي عمل يقوم به التاجر في اطار تجارته أنه قد قام بـ إنه بمقابل، فإذا لم يتم الاتفاق على قيمة المقابل، يتم الرجوع إنوم بله إلى العرف لتحديد

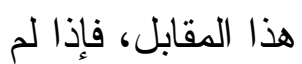

يوجد العرف فلا مناص من أن يقوم القاضي بتقدير المقابل.

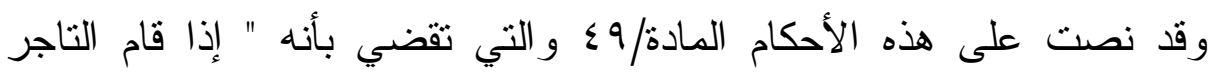

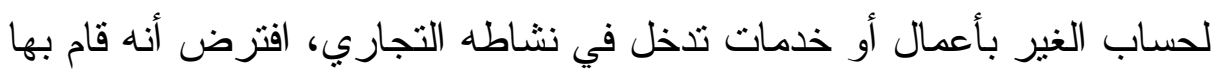

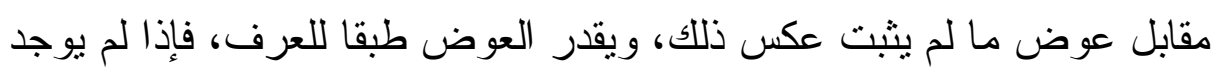

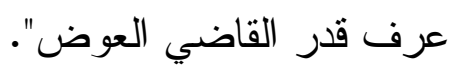
ويعكس هذا الحكم مدى طغيان الجانب المادي على الجانب الأخلاقي في

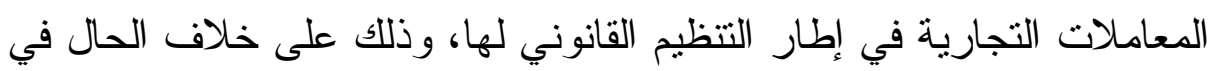

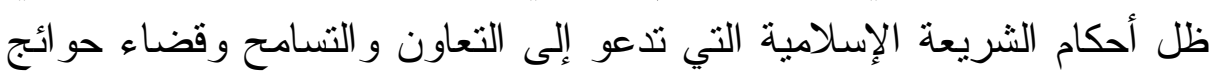

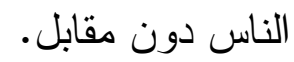

\section{(ثالثا) افتر اض استحالة وقوع مفابل التاجر فريسة للاستغلال}

إذا كان يجوز للشخص وفقا للقو اعد العامة في القانون المدني أن يطلب ابطال

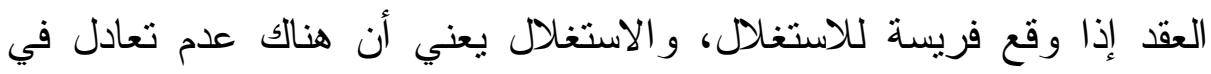

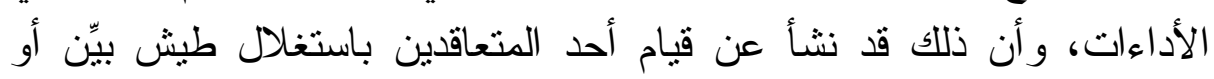

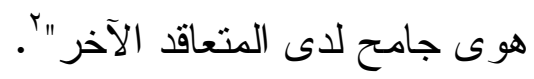
فإن هذه القاعدة لا تتسجم مع اعتبار التاجر شخص التص محترف، فلا يتصور

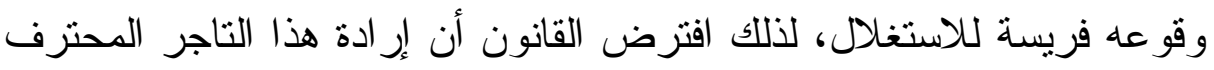

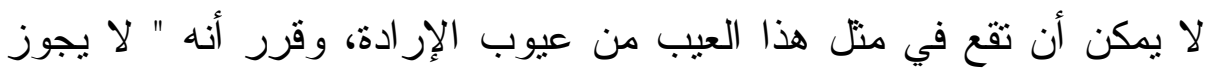

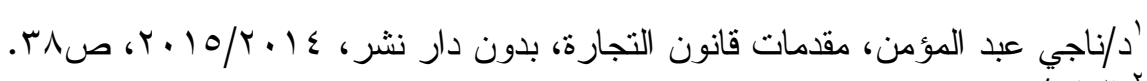

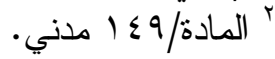


بسبب الاستغلال أو الغبن أن يطلب التاجر ابطال العقود التي يبردها لشئون

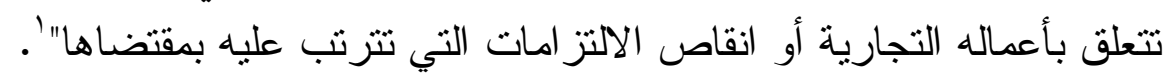

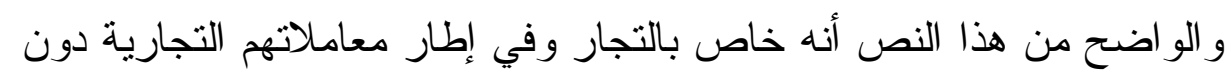
المدنية، وبهذا الحكم يحرم التاجر من حقه المشروع في التمسك ببطلان العقود

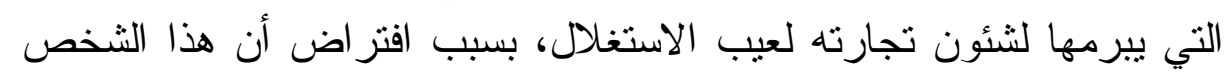

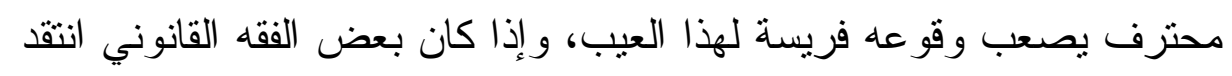

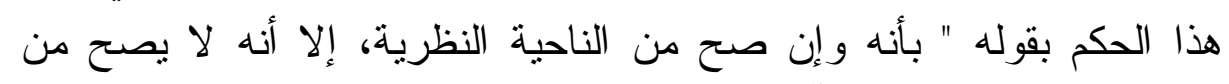

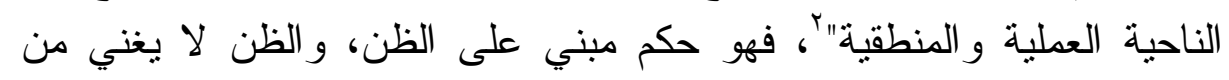

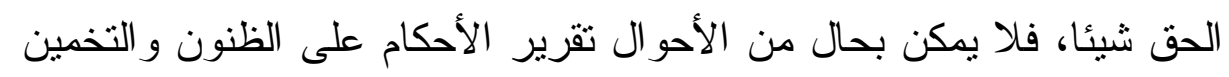

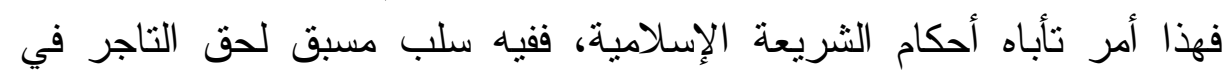
التمسك بهذا العيب نظر المحدودية قدر اته مثلا أو حسن نيته في التعامل مع الته

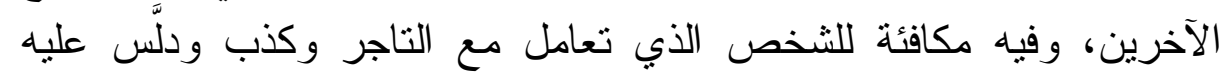

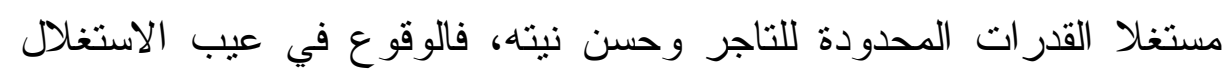
يختلف باختلاف الأشخاص وظروف التعاقد، فلا يجوز إصدار حكم مسبق لـه فئه فله

\section{الاطلب الثاني \\ القواعد التي تدعم الائتسمان في المعاملات التئية التمارية \\ إذا توافرت شروطها}

(أولا) الإقفلاس (أون

نظم قانون التجارة قو اعد خاصة للتنفيذ على التجار، متى تخلفو الإسن عن دفع

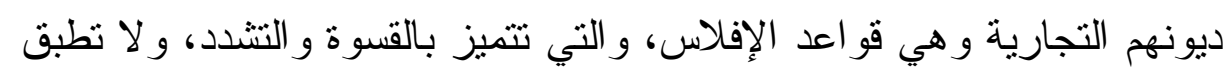

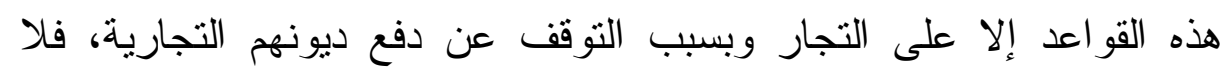
يجوز شهر إفلاس التاجر الذي توقف عن دفع دين مدني، وإن جاز للإن للائن

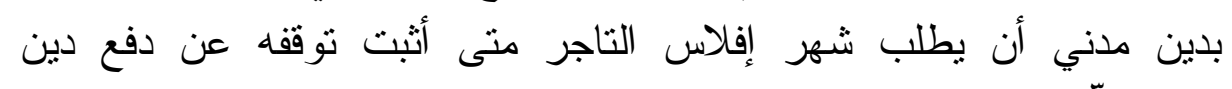

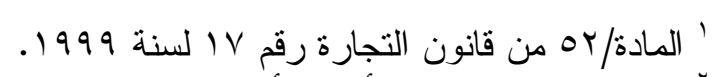

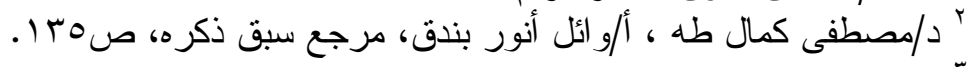

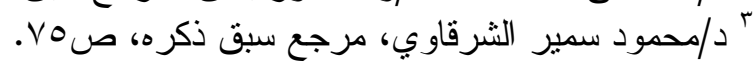

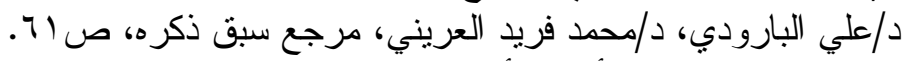

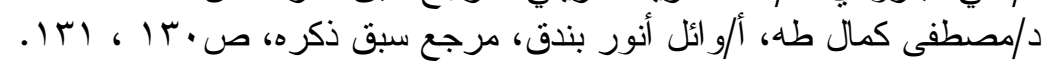


وقد تميزت قو اعد الإفلاس بالقسوة والتشدد تجاه المدين لدعم الائتمان في

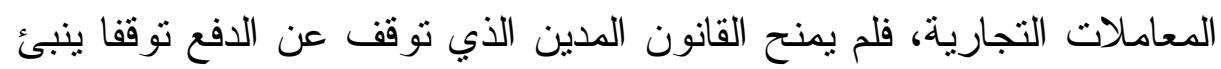
باضطر اب في أحو اله المالية على نحو يضر بحقوق دائنيه بسبب لاني ليد له فيه

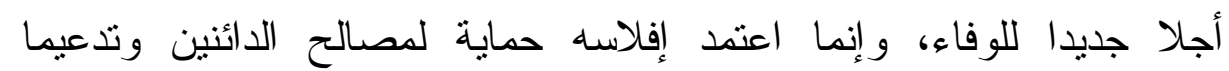

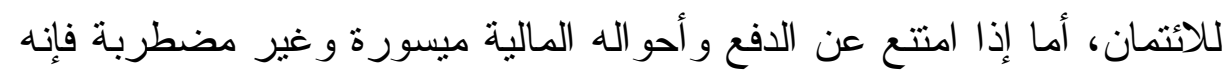

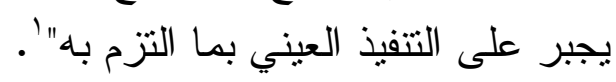

\section{(ثانيا) الفوائد القانونية في حالة التأخر عن سداد الدين الدين}

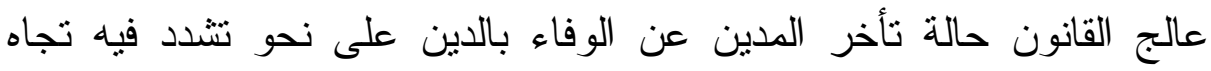
المدين، في سبيله لتدعيم الائتمان في المعاملات التجارية، فمن ناحية لا يمنح

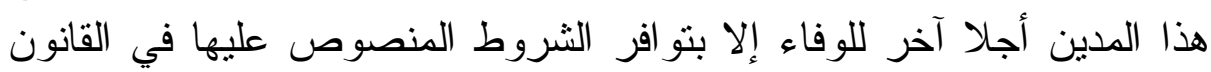

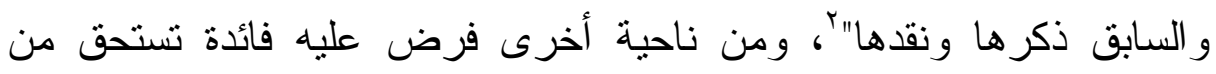

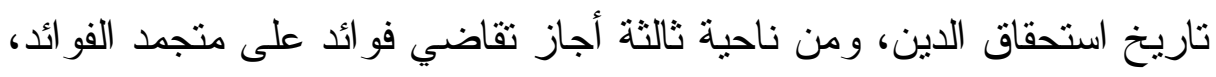

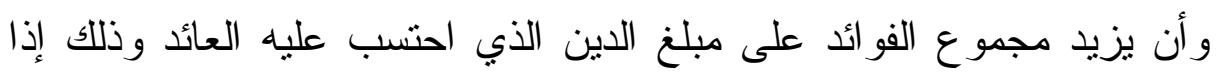

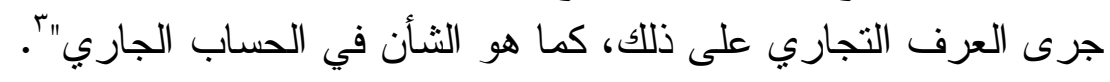

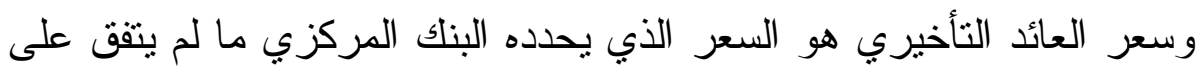

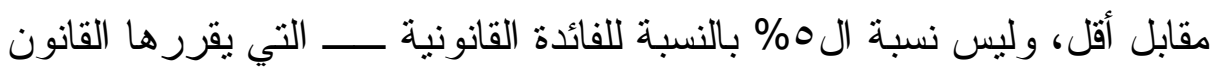

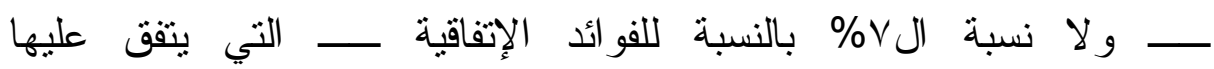

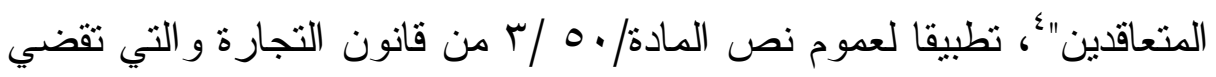

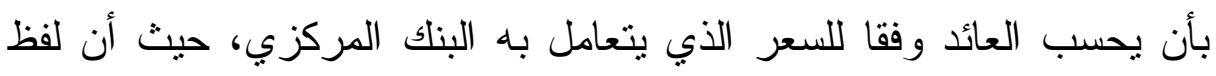
العائد قد ورد في هذه المادة بصيغة عامة، فيشمل كل أنواع العائد، سو اء كان

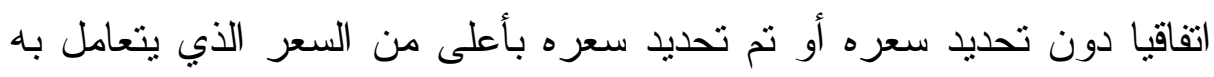
البنك المركزي أو تأخيريا" .

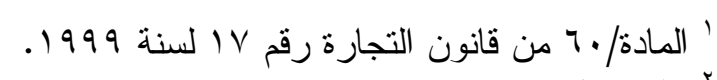

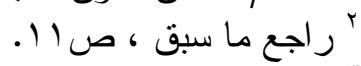

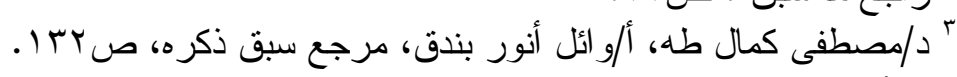

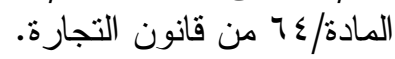

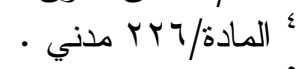

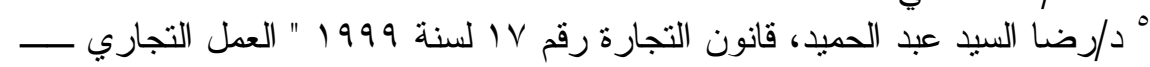

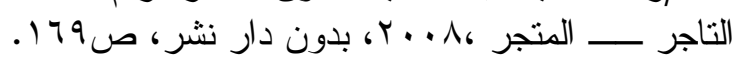


ويؤيد الر أي السابق؛ أن المادة/ه المذكورة جاءت في الأحكام العامة في الباب الثاني و الخاص بالالتز امات و العقود التجارية، ومؤدى ذللك سريانها هل عل هل

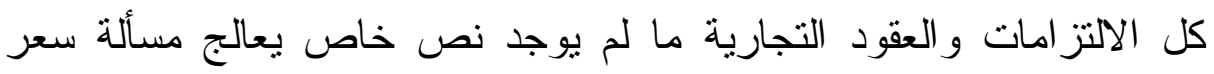

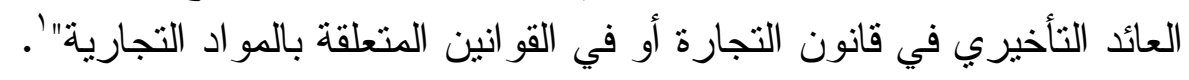

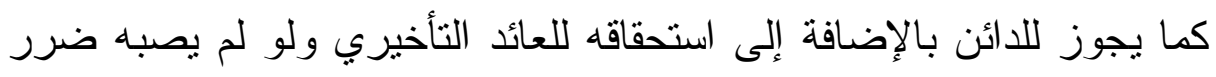

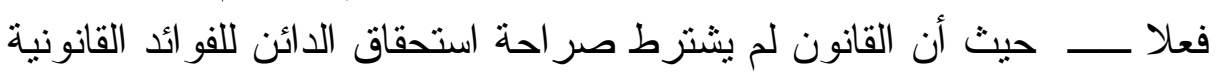

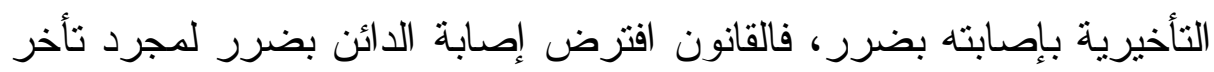

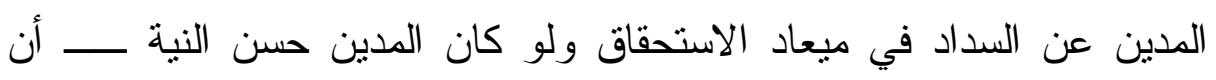
يطالب بتعويض تكميلي عن تأخير الوفاء بالدين، إذا أثبت الدائن أن أن الضران الضرد

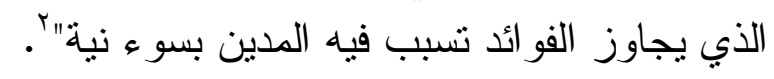

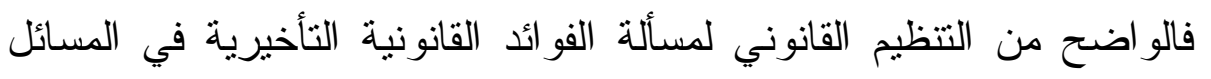

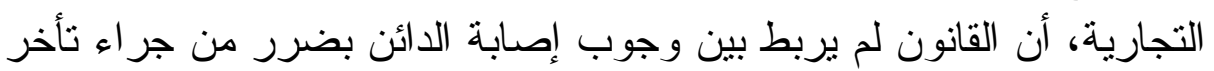

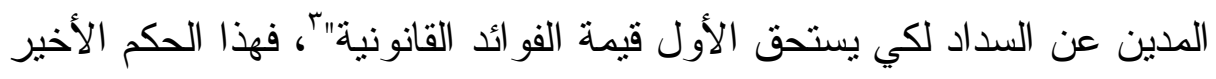

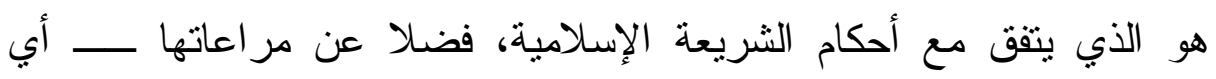

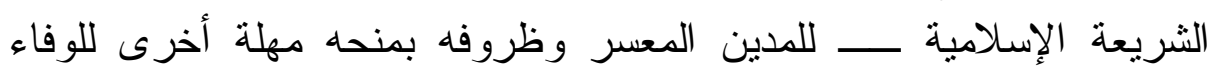
وموازنتها بين مصلحة الدائن ومصلحة المدين وعدم التضحية بأيهما لتدعيم الإين الإئتمان في المعاملات أيا كانت طبي لئنه

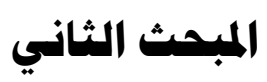

\section{القواعد التي تدعم الإئتسمان في المعامهلات في الفقه الإسلاهي}

حرص الإسلام على تتظيم التجارة وتوفير الضمانات للمعاملات حتى تتوفر فئر التهات

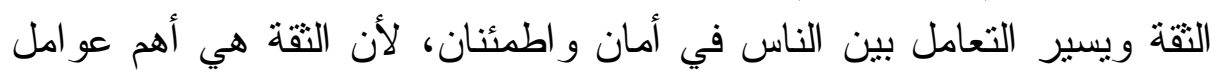

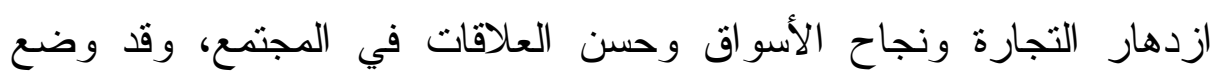

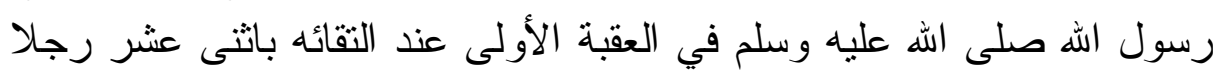

' مثال ذلك ماقضت به المادة/ع ا /أ من قانون البنك المركزي و الجهاز المصرفي و النقا

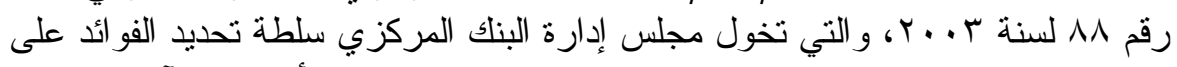

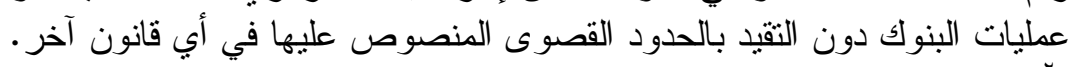

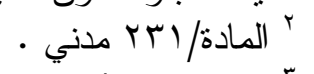

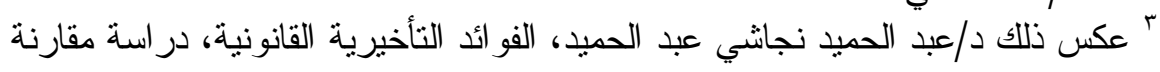

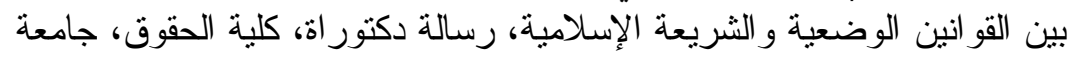

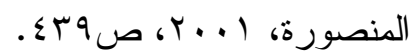




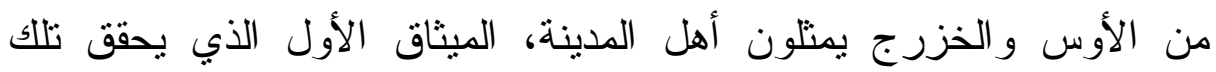

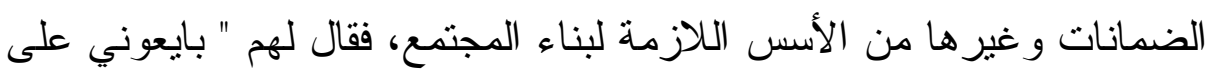

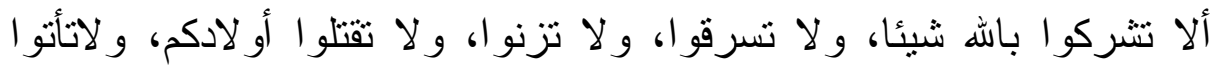

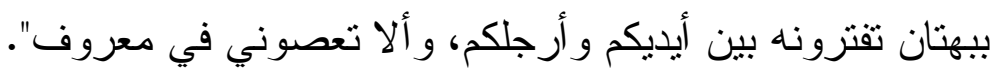

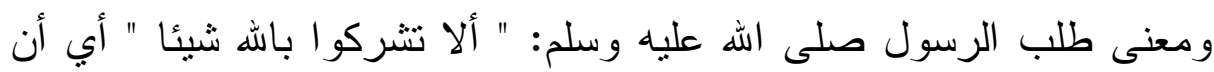

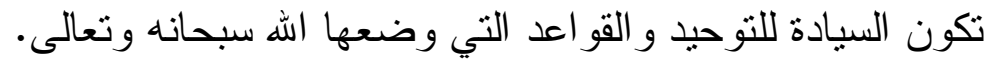

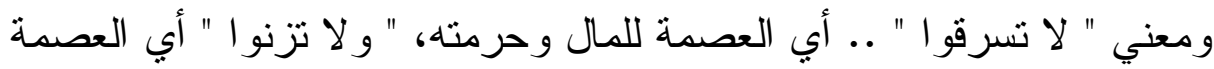

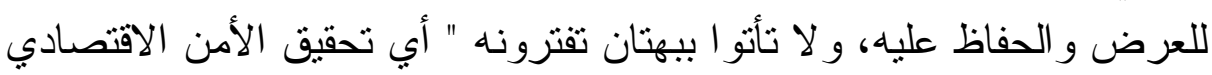

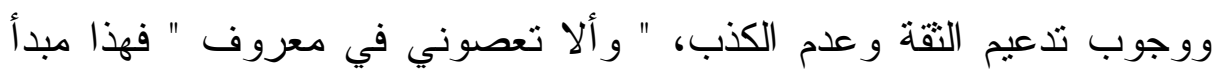

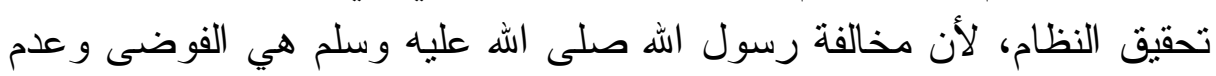

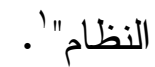
وتظهر تلك الضمانات التي تكفل تحقيق وتدعيم الإئتمان للمعاملات أيا كانت

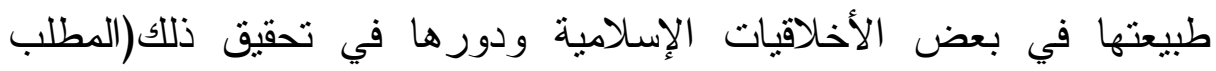

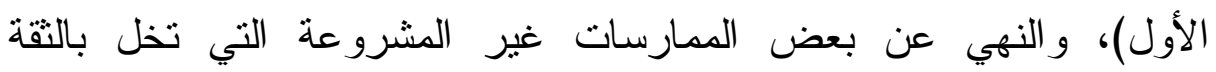

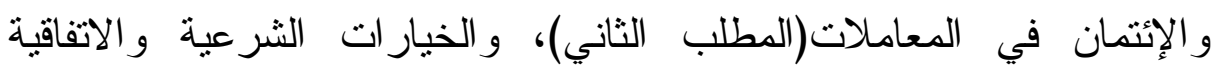

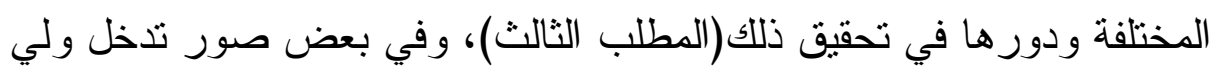
الأمر لتحقيق وتدعيم هذا الأساس الذي تقوم عليه المعاملات (المطلب الر ابع).

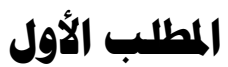

\section{بعض الأخلاقيات الإسلاهية ودورها في تدعيم الإئتسمان في المهاهملات الإنات وديات}

(أولا) منهج التربية الإسدلامية

يثق الثنارع الحكيم كل التقة في المسلم الذي رئبِي على احتر ام العقيدة في ألا يفعل شيئًا يغضب به ربه، فالنظام الإسلامي يقوم على أساس الربط بين الدين

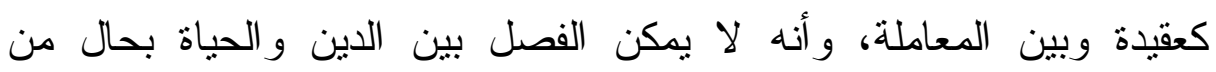

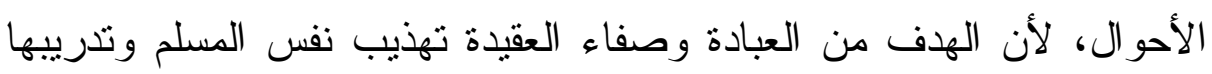

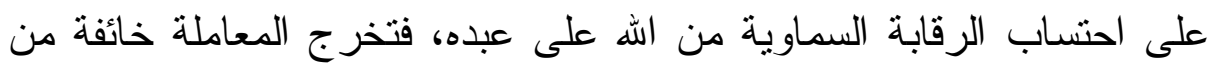

' ا/عبد السميع المصري، مرجع سبق ذكره، صها . 
هذه الرقابة الدائمة للضمير ، فلا تغش و لا تخدع و لا تغبن و لا تدلس ومن هنا

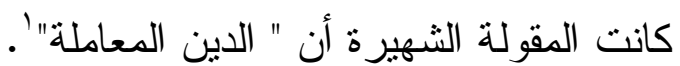

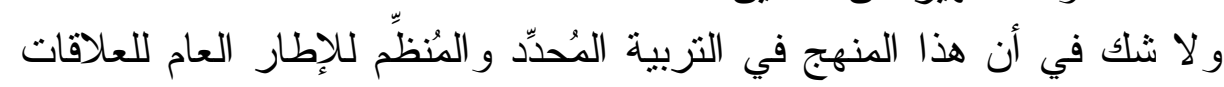

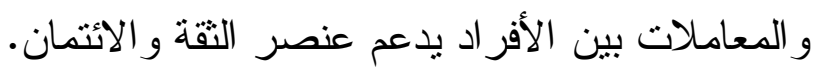

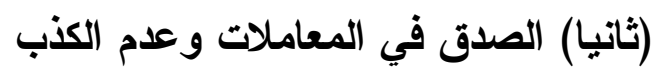

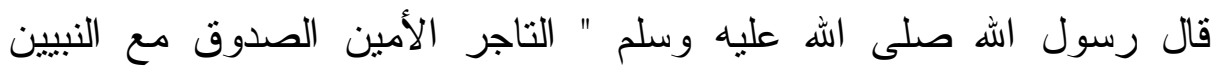

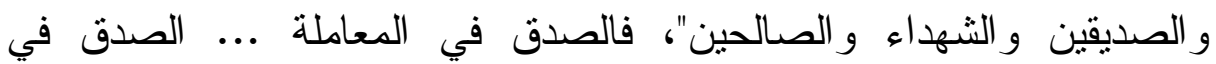

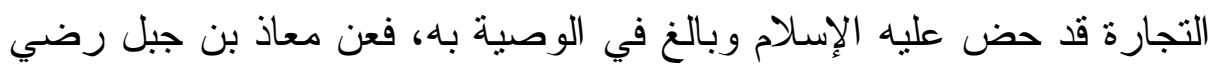

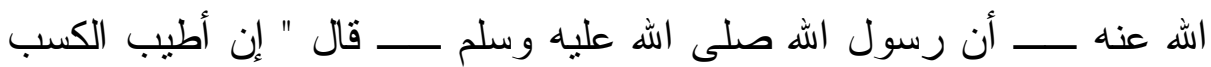

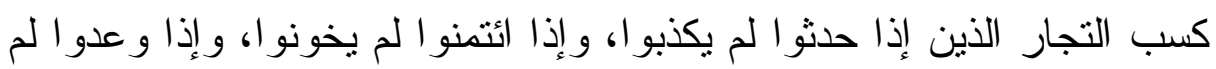

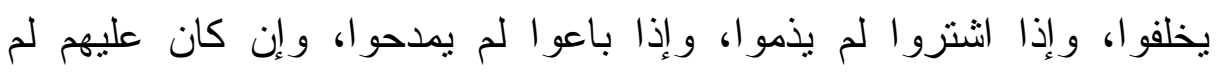

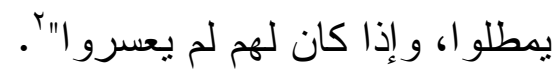

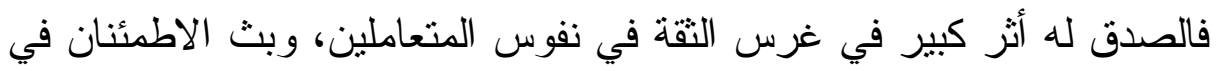

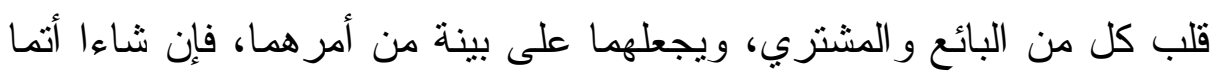

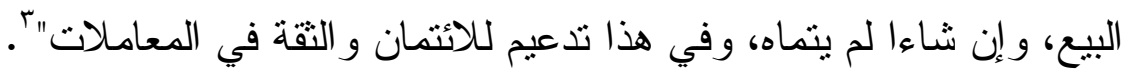

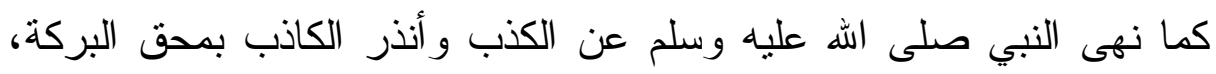

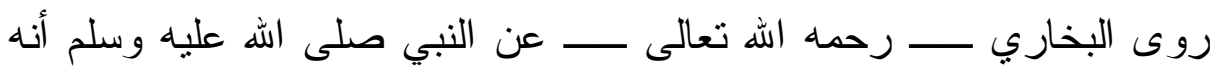

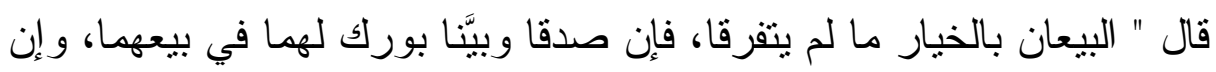
كتما وكذبا محقت بركة بيعهما". ويقول تعالى في الرجل يقسم لينفق سلعته أو ليغش المشتري " إن الذين

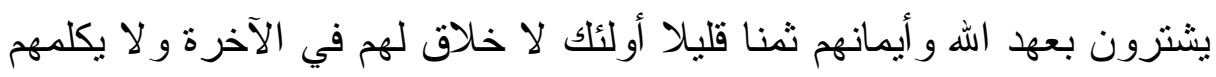

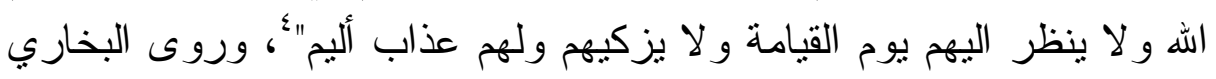

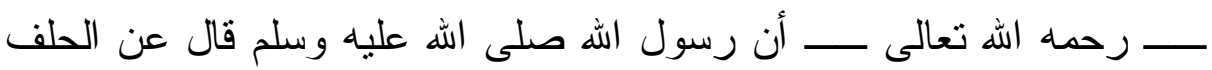
الكاذب " الحلف منقصة للسلعة ممحقة للبركة".

د/ محمد نجيب عوضين المغربي، أهم النظريات الفقهية في التشريع الإسلامي، دار

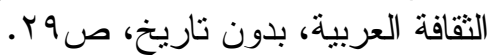

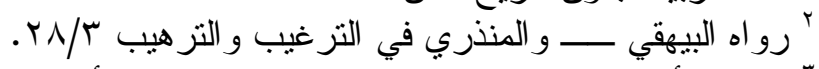

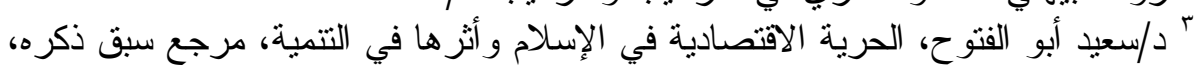

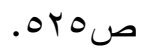
ع سورة آل عمران الآية/VV. 


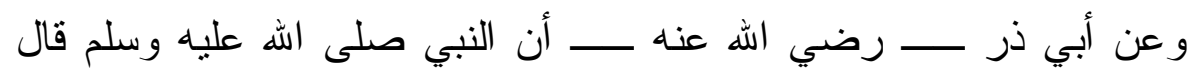
ثلاثة لا ينظر الله إليهم يوم القيامة و لا يزكيهم ولهم عذاب أليم. قال فأعادها رسول الله صلى الله عليه وسلم ثناث مرات فقلت : خابو ا وخسرو ا. ومن هم

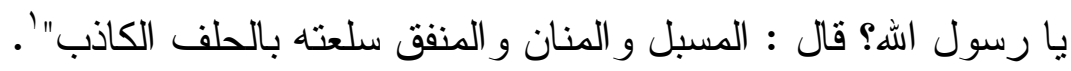
وبالتحذير من الكذب و الحلف و الثناء على السلعة قد سد الإسلام على البائع بابا خطير ا من أبو اب التغرير بالمشتزي وخداعة، ويؤدي ذلك إلى تدعيم الثقة

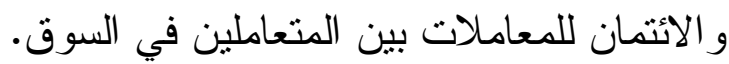

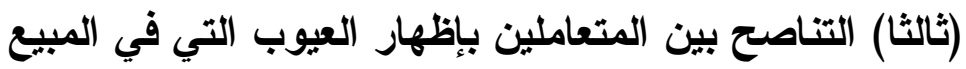

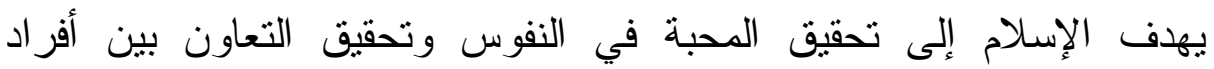

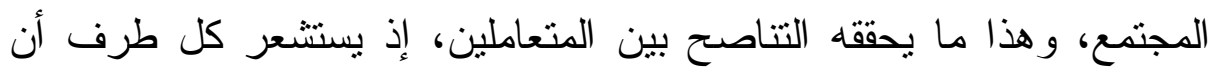

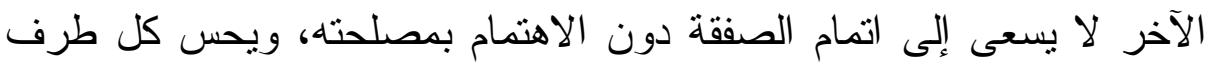

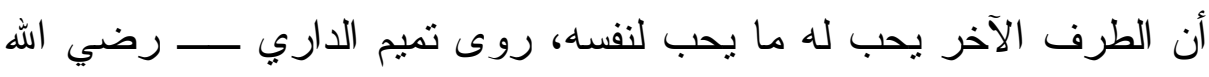

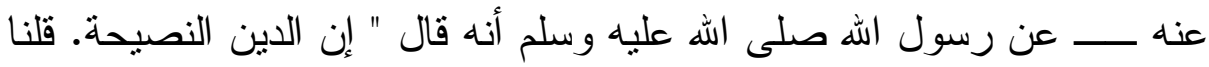

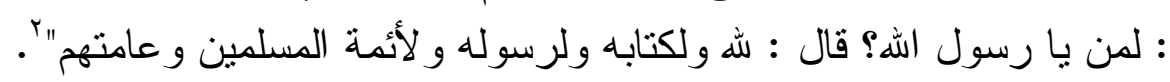

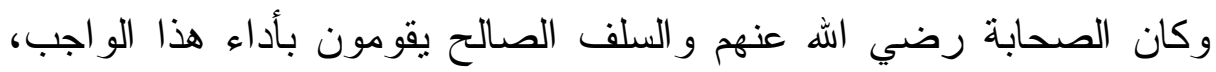

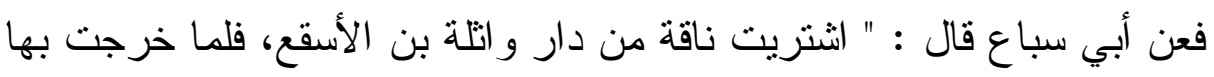

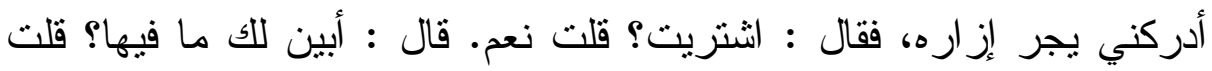

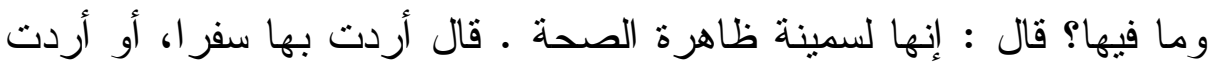

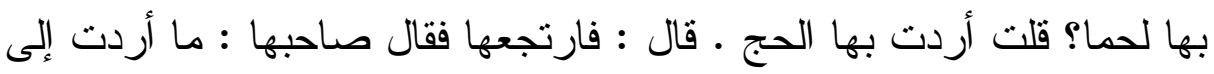
هذا أصلحك الله تفسد على ـ قال : إني سمعت رسول الله صلى الله عليه وسلم

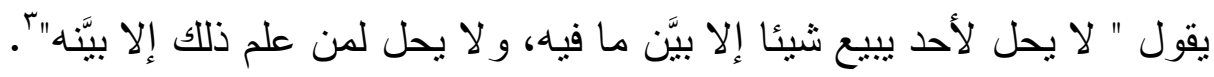

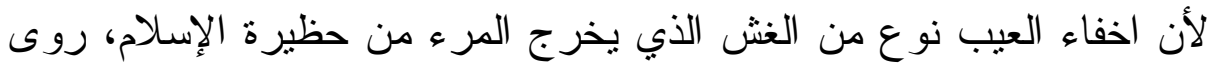

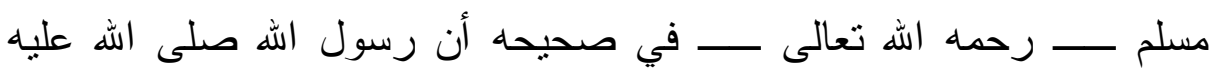
وسلم قال " من غشنا فليس منا "، و الإسلام في هذا يسير على فو اعده الخلقية

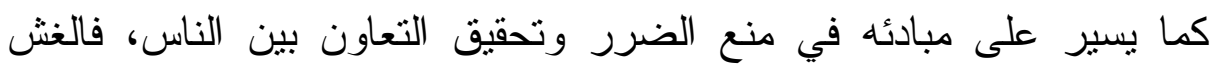

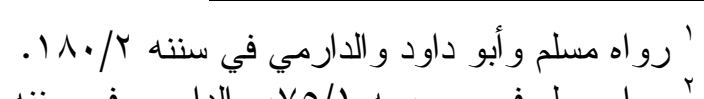

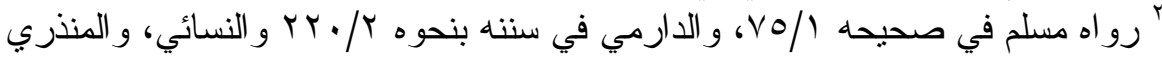

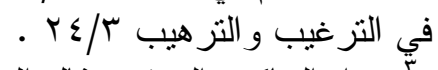

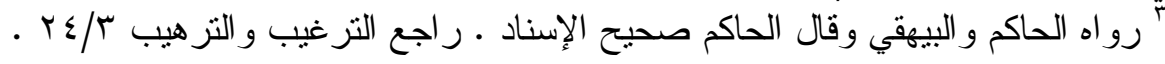


قذارة ضمير و اضر ار بالآخرين ورفع للتقة من صدور الناس، و لا تعاون في

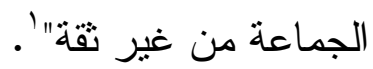
وفي ظل هذا الخلق الكريم، تبنى المعاملات في الإسلام على الثقة والبيان

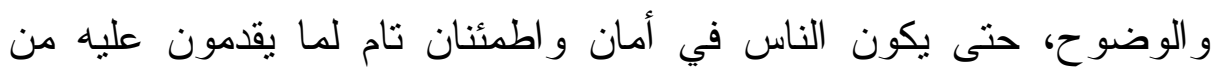

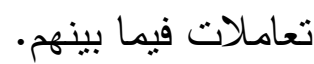

\section{(رابعا) رفع الضيق والحرج بإقالة النادم عثرته بـانه}

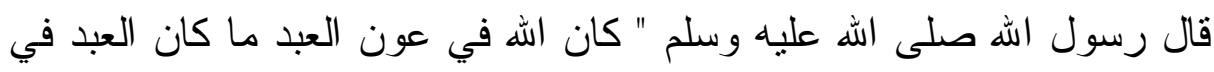

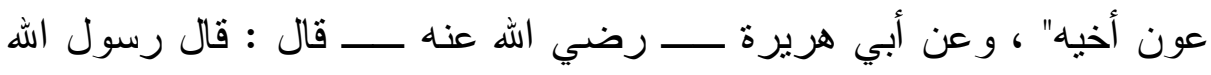

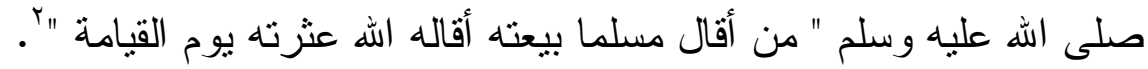
وقبول الإقالة خلق كريم يعكس مدى ثقة المسلم فيما عند الله، على ما في يديه

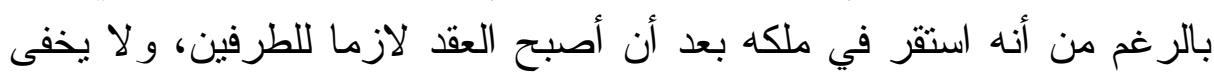

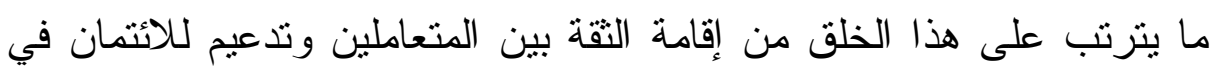

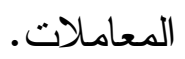

\section{(خامسا) الأمانة وعدم الخيانة}

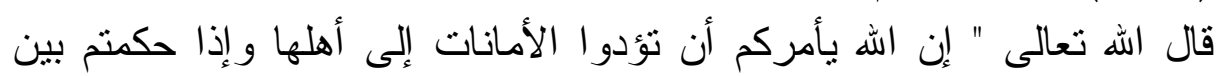

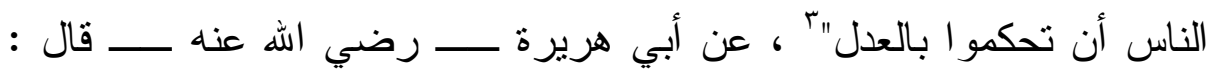

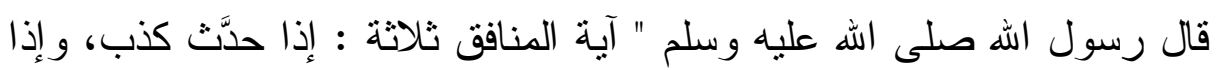

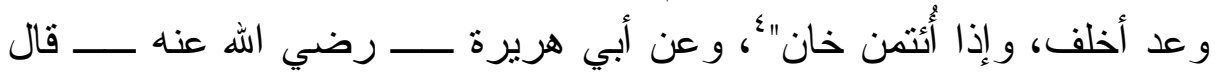

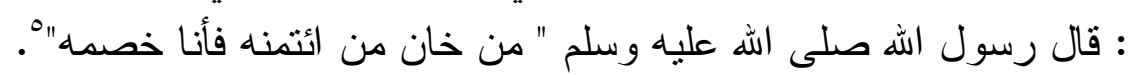

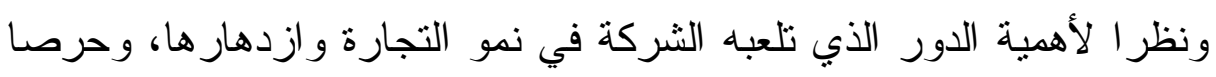

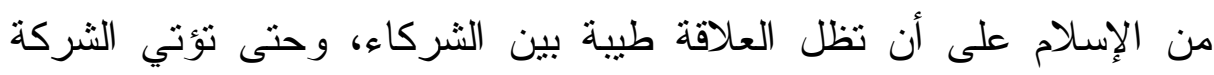

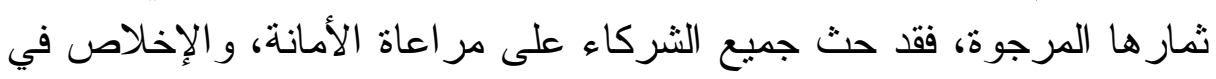

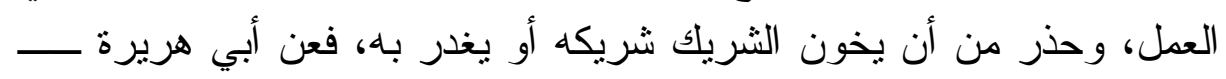

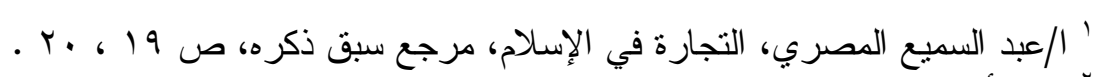

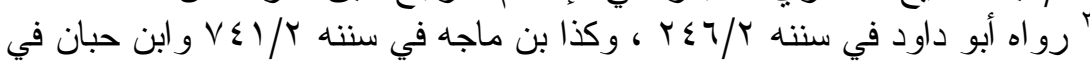

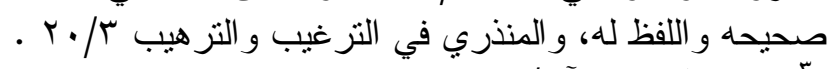

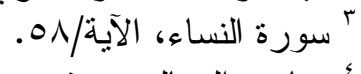

" رياض الصالحين، شرح الإمام النووي، كتاب المقدمات، باب الأمر بأداء الأمانات رقم:

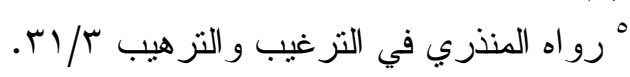




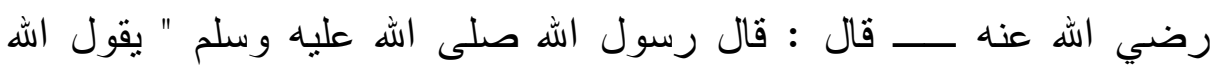
تعالى : أنا ثالث الثريكين ما لم يخن أحدهما صاحبه، فإن خان خرجت من فن اله

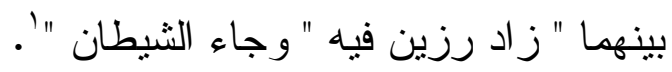

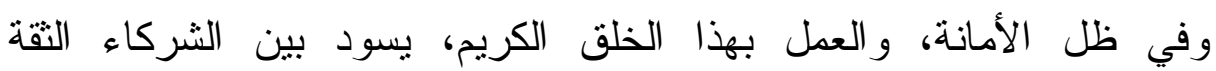

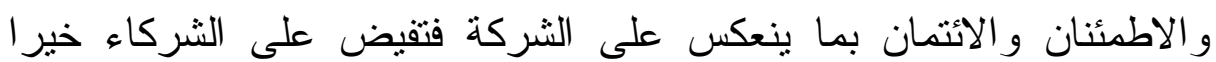

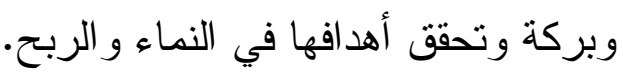

\section{الإطلب الثاني \\ النهي عن بعض المهارسات غير المشروعة التي التهل بالثقة والائتسمان في المعاهيسات فير المائلات}

(أولا) تحريم الربا

قال الله تعالى " الذين يأكلون الربا لا يقومون إلا كما يقوم الذي يتخبطه

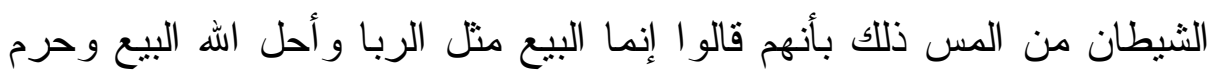

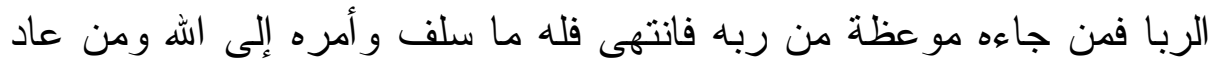

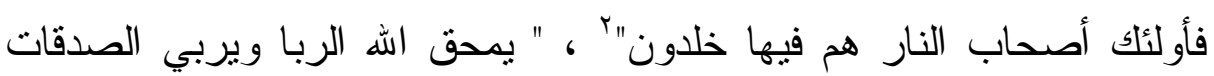

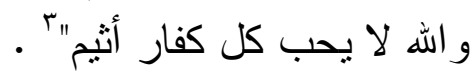

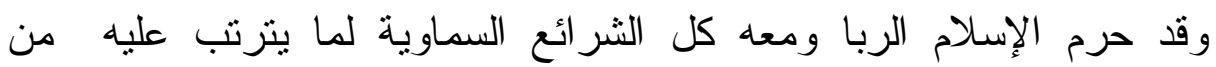
المضار الاقتصادية و الاجتماعية، فمن مضارة الاقتصادية؛ أنه يمنع الاستثمار

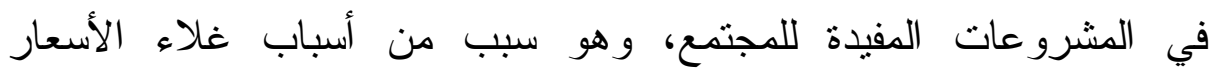

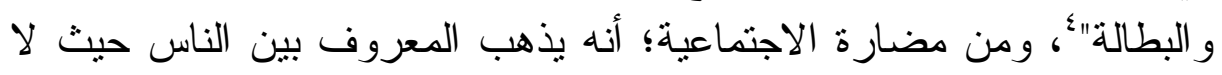

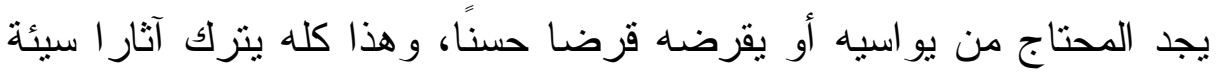

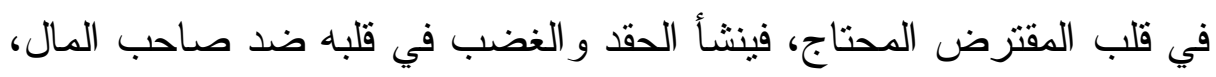

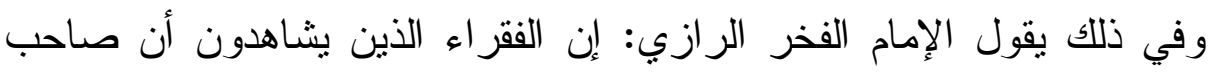

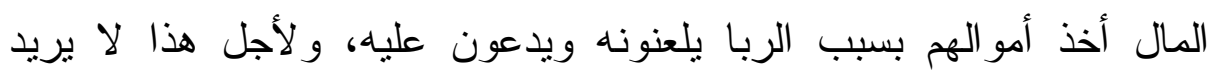

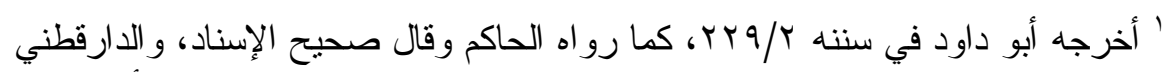

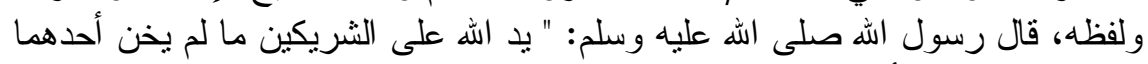

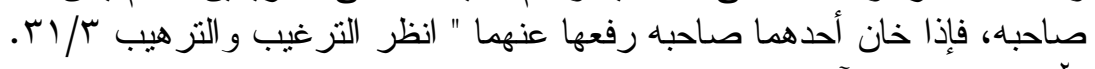

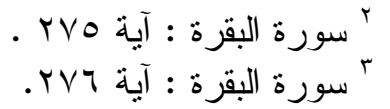

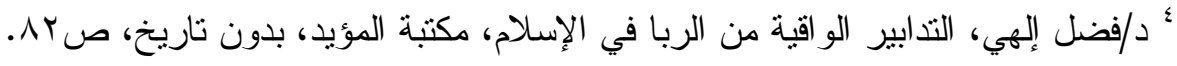


المدين في كثير من الأحيان دفع ما يجب في ذمته من أصل أو ربا إلا مكرها،

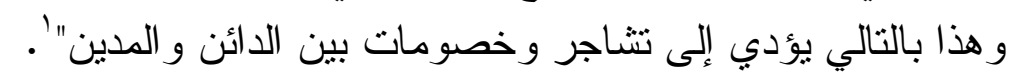

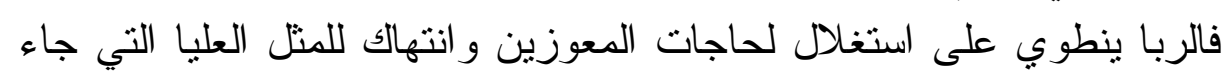
بها الإسلام و التي تحض على التآخي و التعاون و التكافل بين الناس، فتنشأ بذلك الته

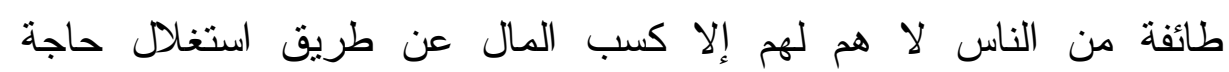

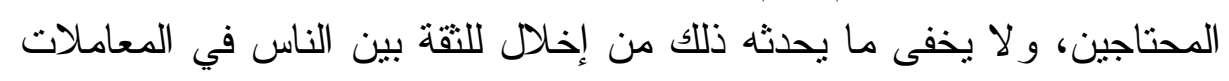

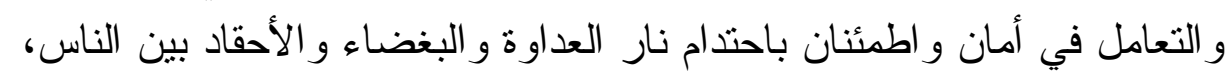

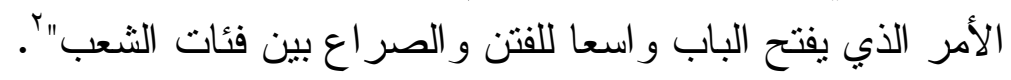

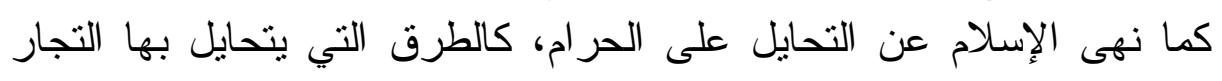
على أكل الربا بما يستعملونه من البياعات الوهمية كعملية بيع السكر أو الأرز

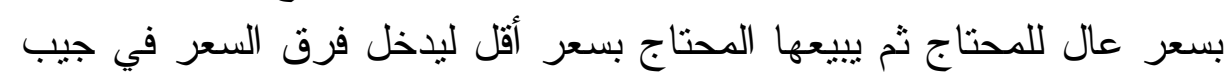

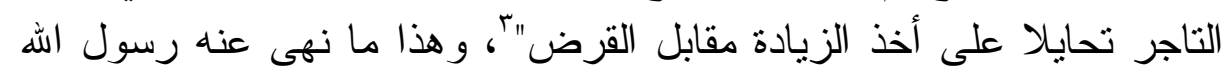

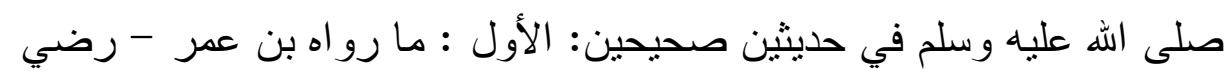
الله عنهما - قال : سمعت رسول الله صلى الله عليه وسلم يقول " إذا تبايعتم

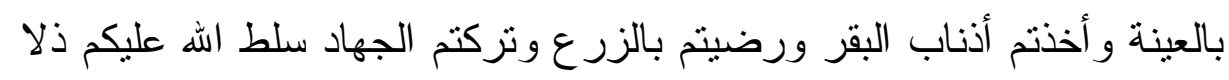

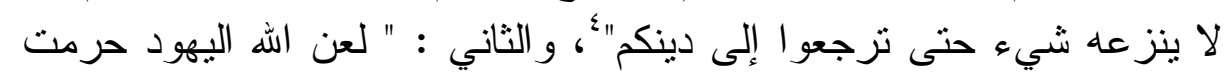

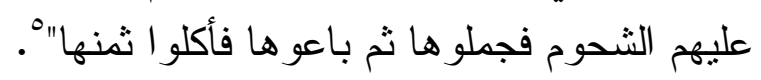

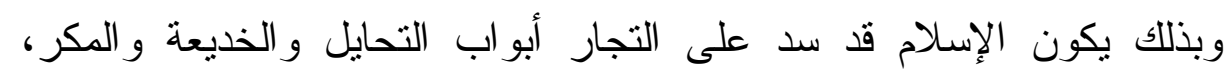
وردهم عن طريق من طرق أكل أموال الناس بالباطل، حتى تظل الته حياة

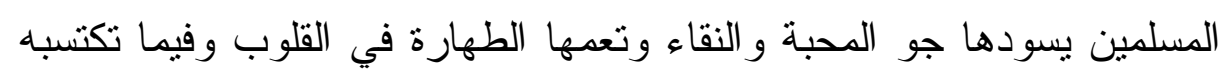
الأيدي"، فضلا عن تحقيق الثقة بينهم في معاملاتهم.

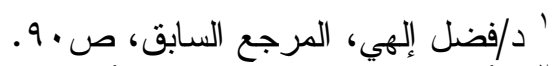

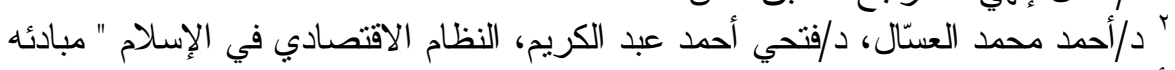

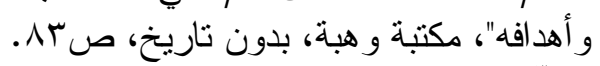

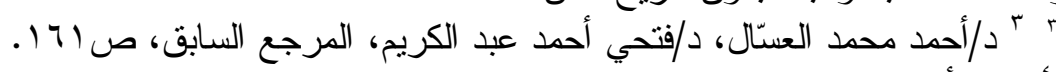
" رو اه أبو داود، و اللفظ لهد. " رو اه البخاري. " د/سعيد أبو الفنتوح، الحرية الاقتصادية في الإسلام و أثز ها في النتمية، مرجع سبق ذكره، صع 
الغرر مداره على أمرين : أولهما: وجود جهالة في المبيع، وثانيهما: وجود التئرد

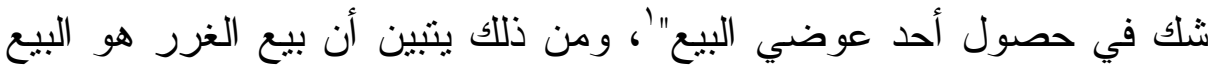

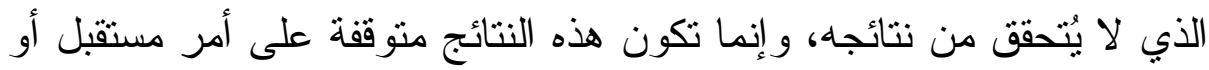

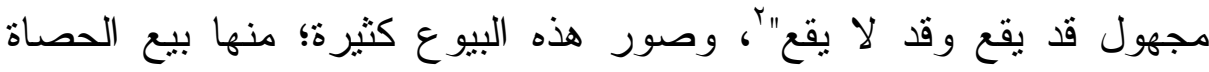

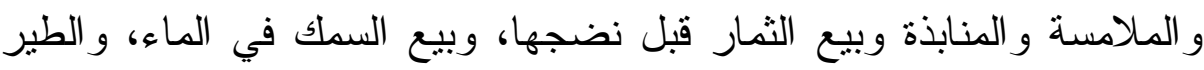
في الهواء، وبيع حمل الحيو ان قبل و لادته .......إلخ. وتحريم هذا النوع من البيوع ثابت بسنة رسول الله صلى اله عليه وسلم :

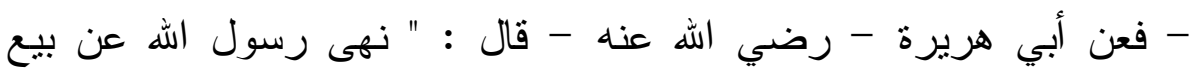

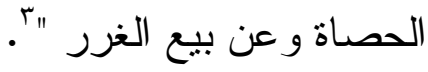
- وعن أبي هريرة - رضي الله عنه - قال " نهى رسول الله صلى الله عليه

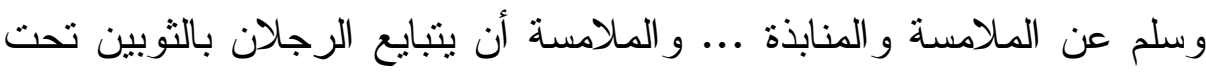

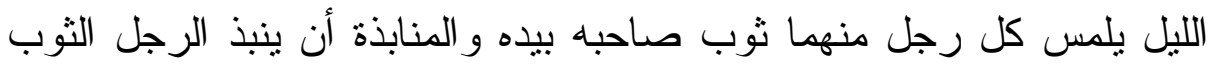

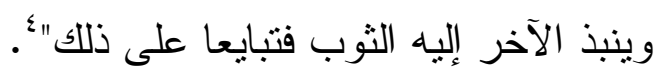

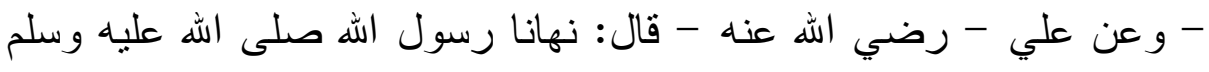

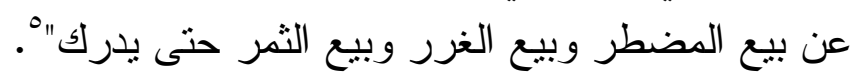
- وعن ابن عمر - رضي الله عنهما - قال: قال رسول الله صله صلى الله عليه

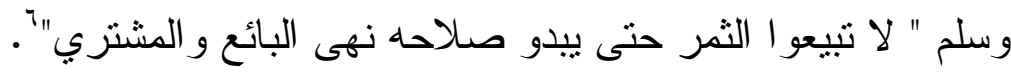
- و عن أنس بن مالك - رضي الله عنه - قال : أن رسول الله صلى الله وله عليه وسلم " نهى عن بيع الثمار حتى تزهى قيل يا رسول الله وما تزهي قال حتى رنى

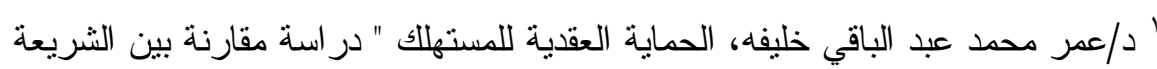

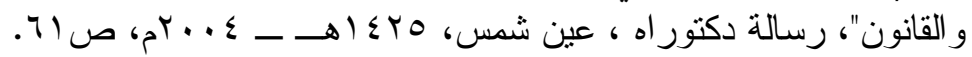

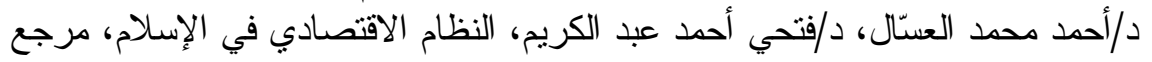

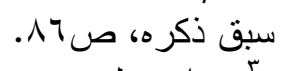

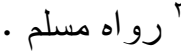

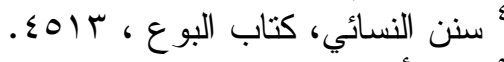

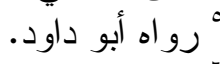

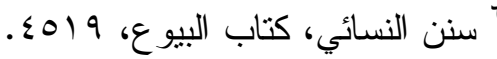


تحمر وقال رسول الله صلى الله عليه وسلم أر أيت إن منع الله الثمرة فبم يأخذ

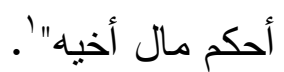

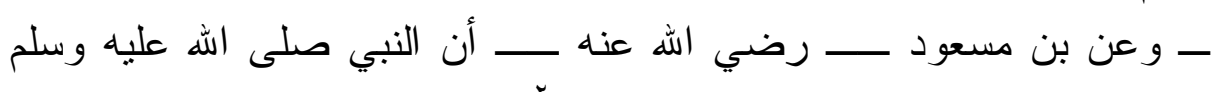

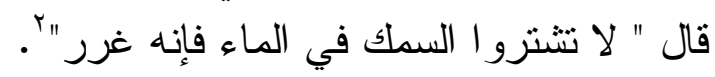

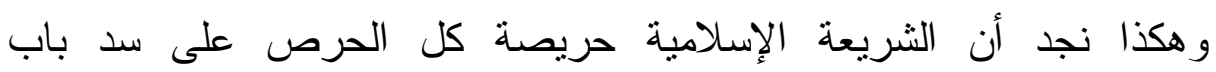
المنازعات و الخلافات بين الناس في معاملاتهم، وهي بذللك تحقق التقة بين الناس في معاملاتهم، وتدعم الائتمان اللازم لهم حتى لا يأكل مسلم مال أخيه

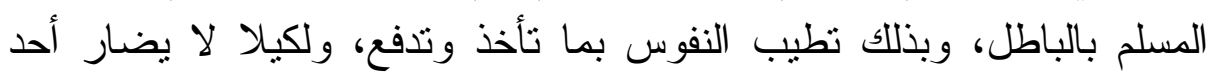
طرفي العقد، و الرسول صلى الله عليه وسلم يقول " لا يحل مال امرئ مسلم إلا بطيب نفس منه"، وبذللك تتحقق الثقة ويسود الائتمان بين المتعاملين في

\section{(ثالثا) النهي عن تطفيف الكيل والميزان}

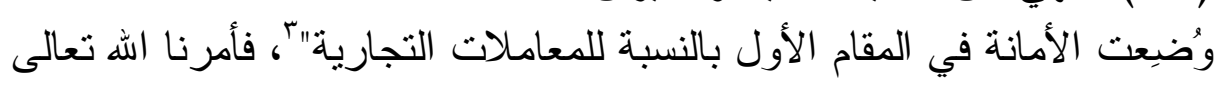

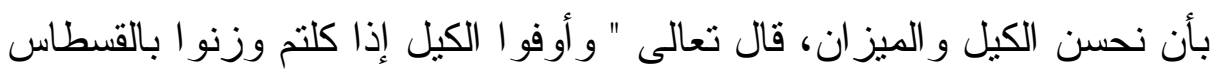

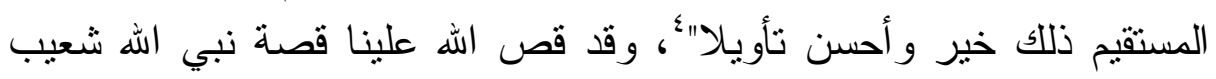

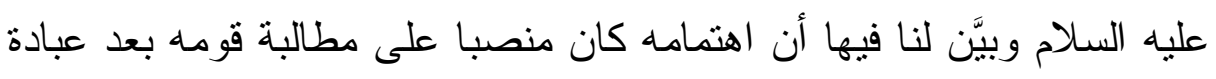

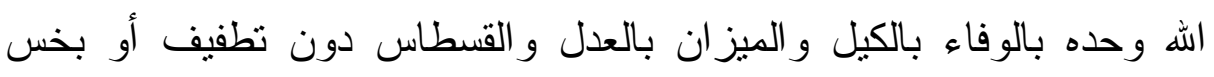

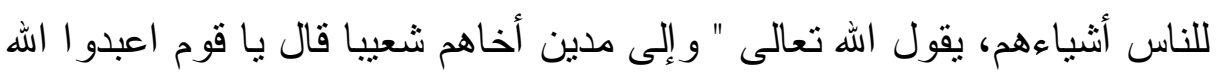

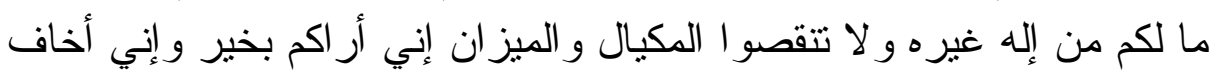

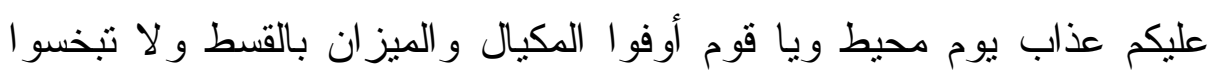

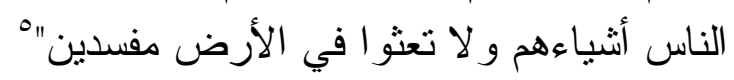

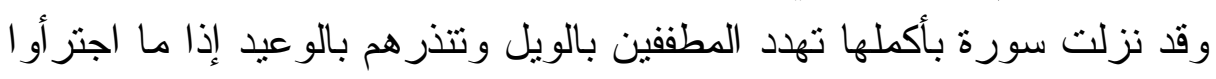

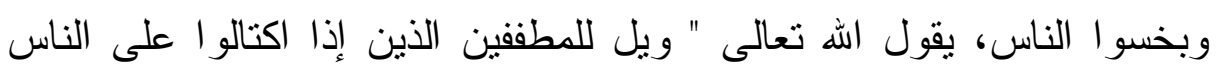

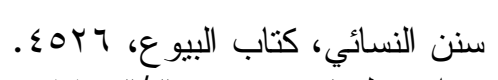

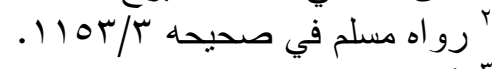

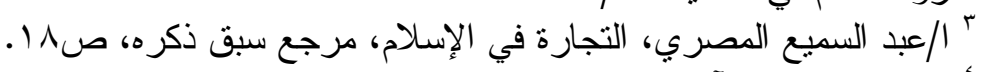

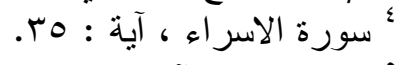

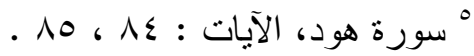


يستوفون و إذا كالوهم أو وزنوهم يخسرون ألا يظن أولئك أنهم مبعوثُون ليوم

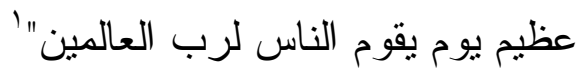

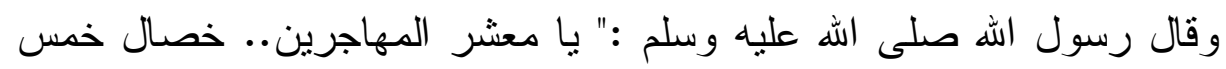

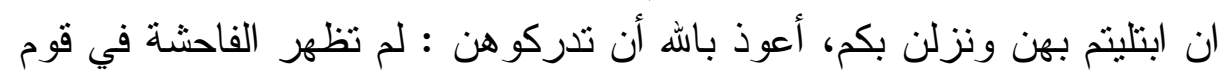

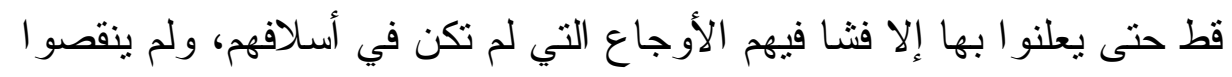

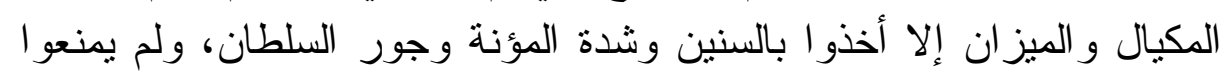

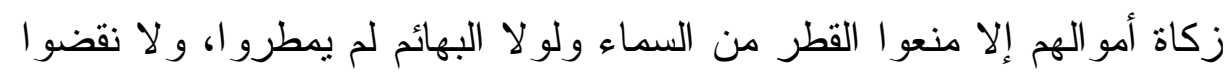

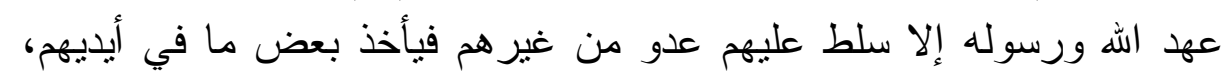

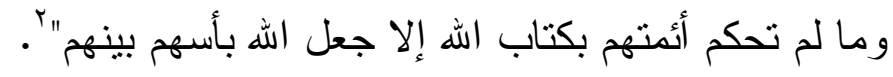

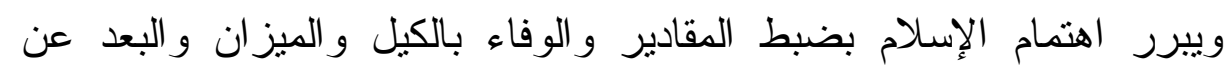

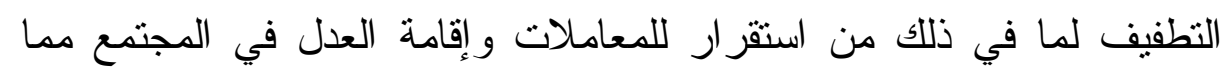

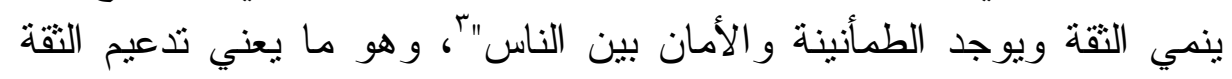

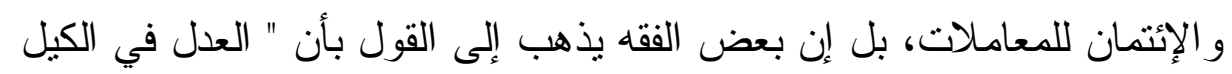

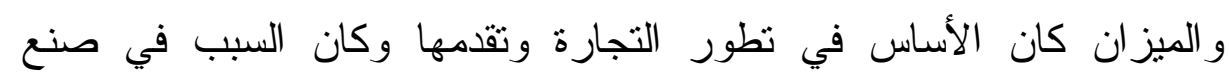
المكاييل و الموازين النمطية التي تطمئن كل طرف في في العملية التجارية إلى ولى حقه" حأ.

\section{(رابعا) النهي عن بيع الرجل على بيع أخيه}

ربط رسول الله صلى الله عليه وسلم بين الأخوة و التعامل التجاري:

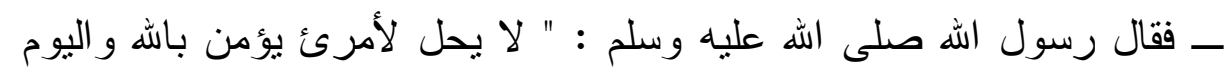

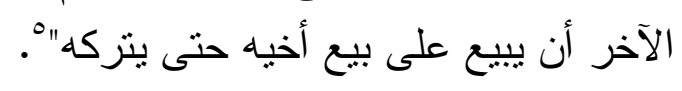

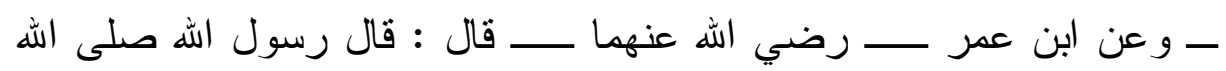

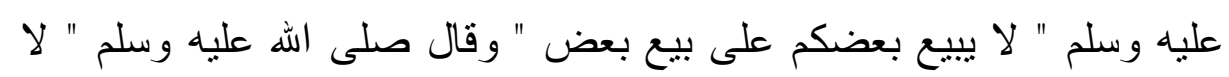
يبيع الرجل على بيع أخيه، و لا يخطب على خطبة أخيه إلا أن يأذن له" لها؟.

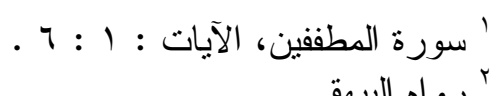

$$
\begin{aligned}
& \text { r بَ رواه البيهقي }
\end{aligned}
$$

r ب/أحمد محمد العسَّال، د/فتحي أحمد عبد الكريم، النظام الاقتصادي في الإسلام، مرجع

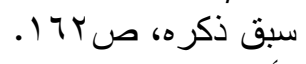

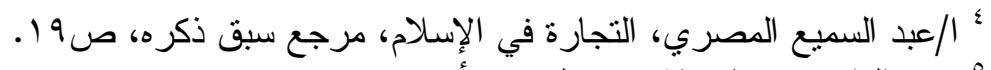

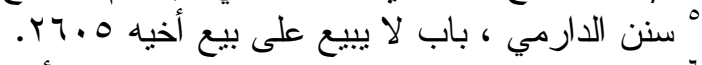

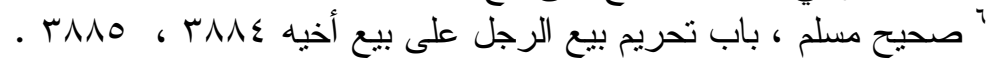


ويريد رسول الله صلى الله عليه وسلم من هذا الربط؛ أن يعمق شعور الأخوة بين المسلمين ليكون لذلك أثره في حياتهم العملية، وليحول بينهح وبين ما قد ولد

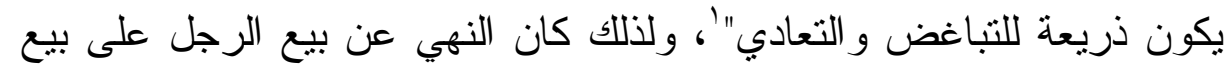

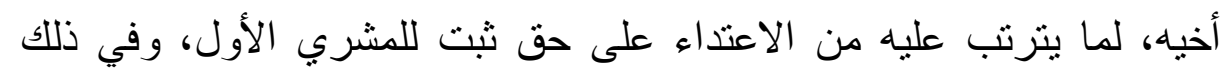

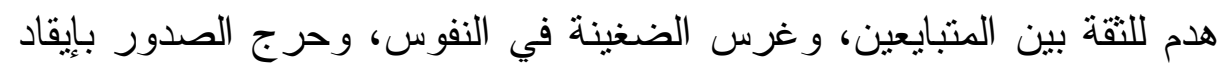

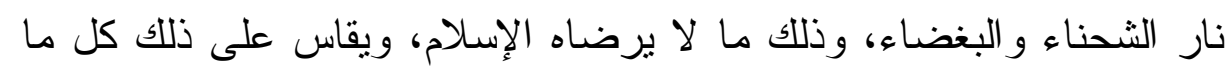

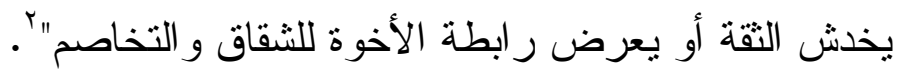

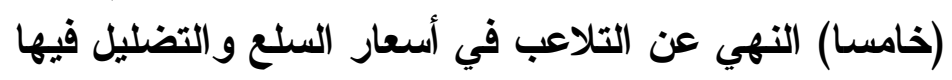

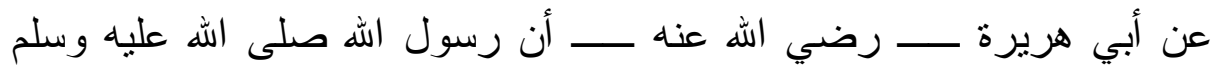

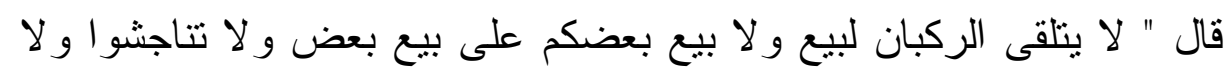

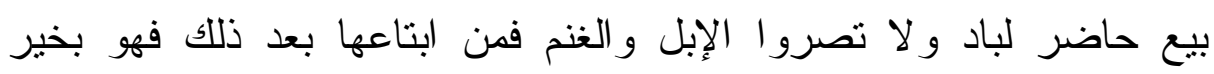

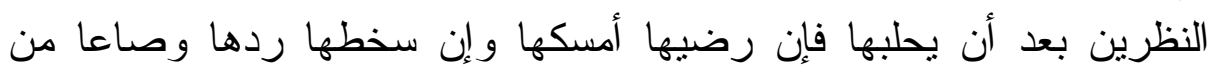

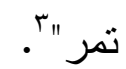

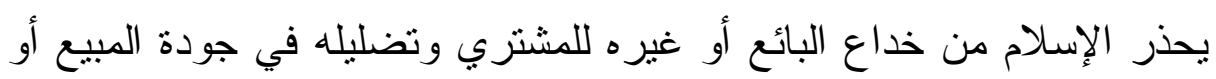

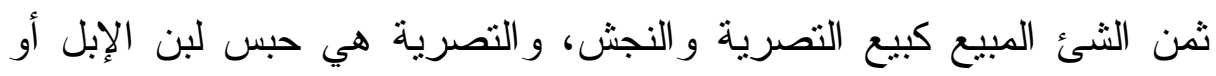

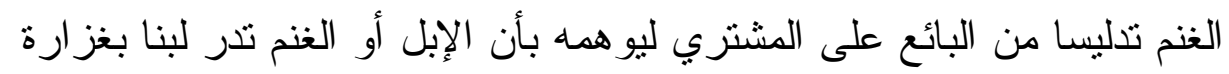

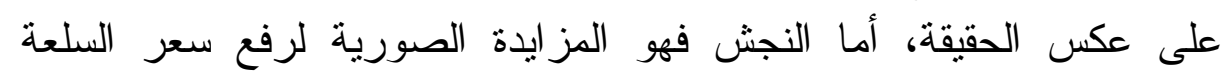

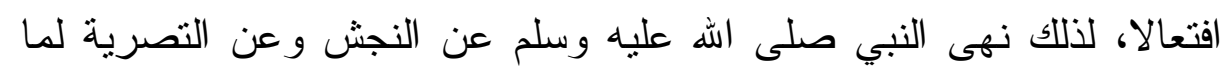
فيها من تغرير بالمشتري يخل بالثقة التي تقوم عليها المعاملات بين الناس،

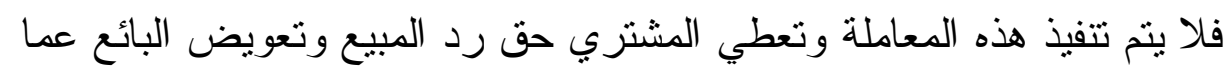

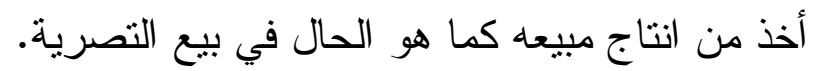

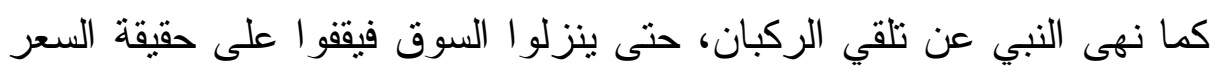

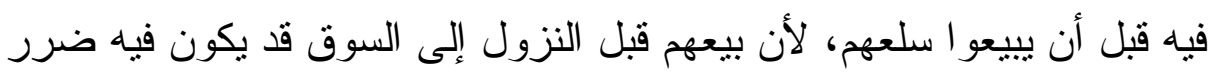
لهم، خصوصا إذا غرر بهم المشتري.

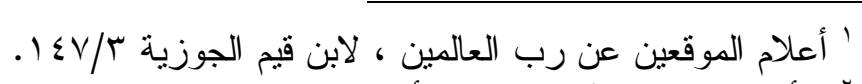

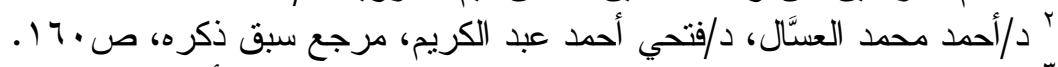

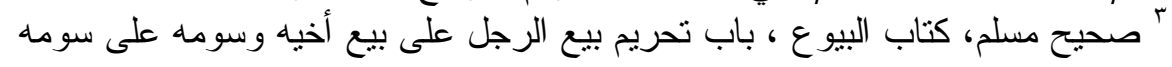

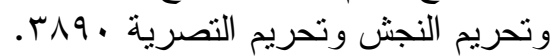


وفي هذا التوجيه الإسلامي ضمان كاف لكل من البائع و المشتري أن يأخذ حقه

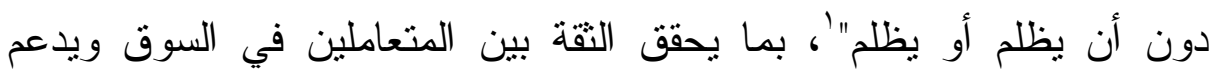
الإيتتمان الذي تقوم عليه التجارة.

$$
\text { (سادسا) تحريم الاحتكار }
$$

يحرص الإسلام على توفير القو اعد التي تحقق التقة بين المتعاملين في السوق الستون

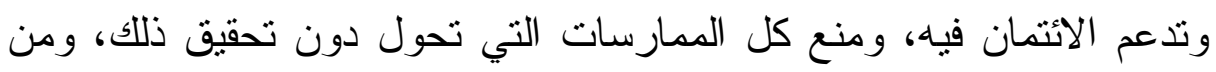

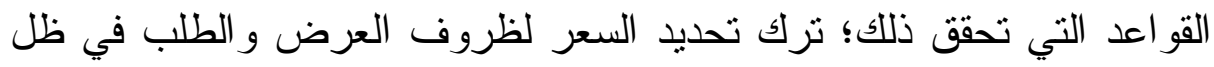

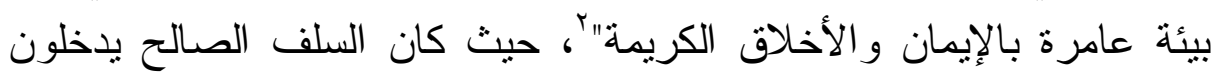

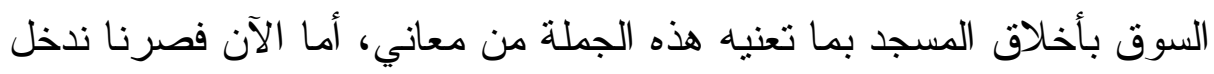

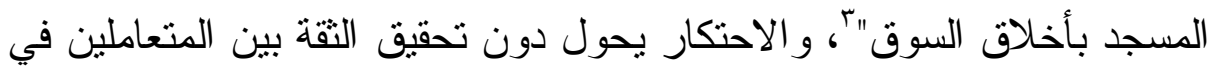

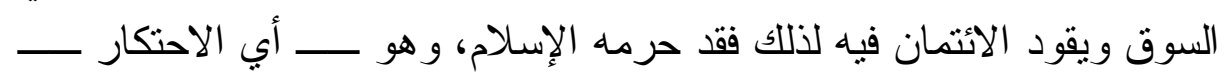

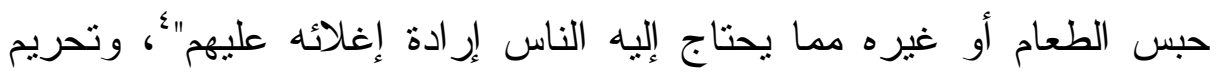
الاحتكار ثابت بالسنة النبوية المطهرة:

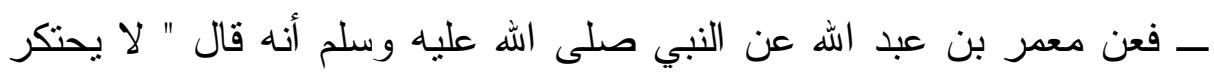
إلا خاطئ ". فعن معر بن

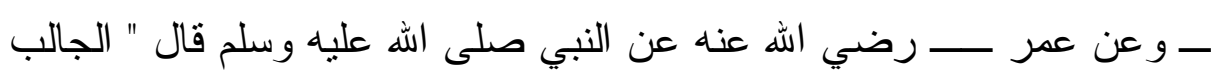

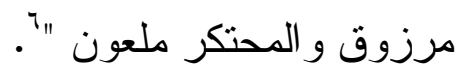

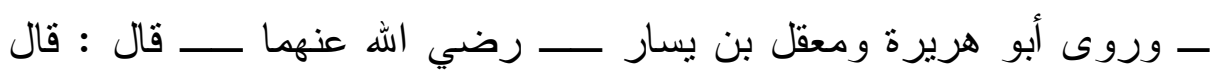

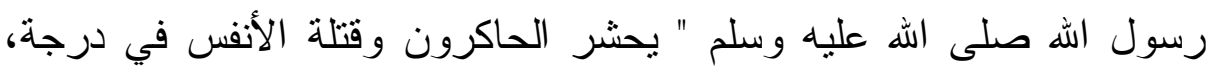

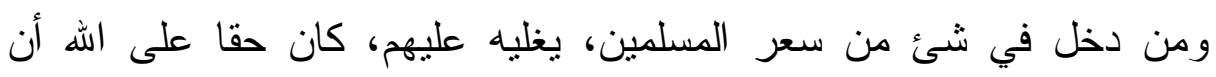

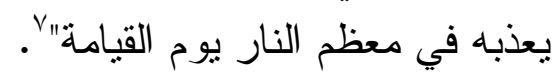

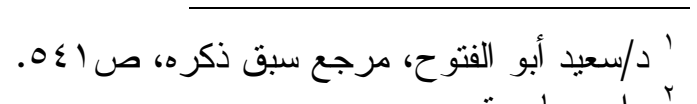

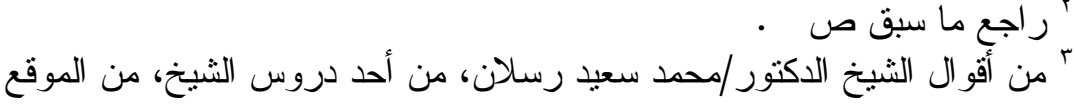

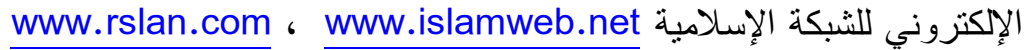

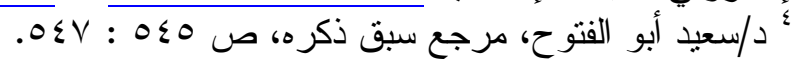

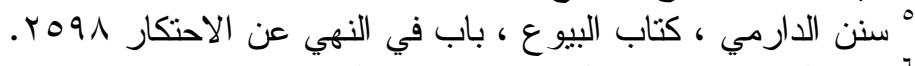

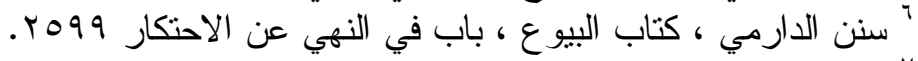

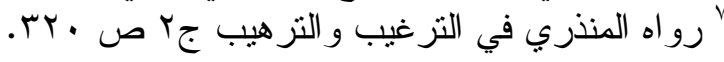


"و القول بوجوب منع الاحتكار حق، مثنال ذلك أن يمتنع أرباب السلع من بيعها

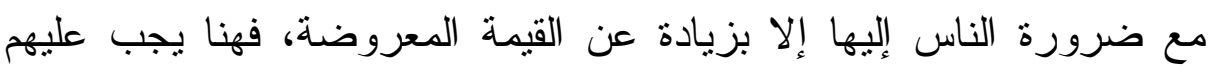

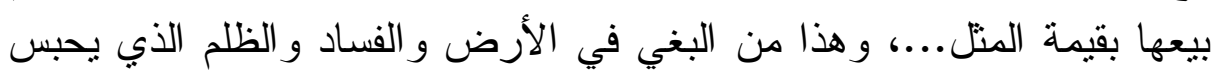

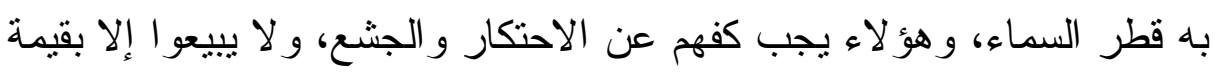

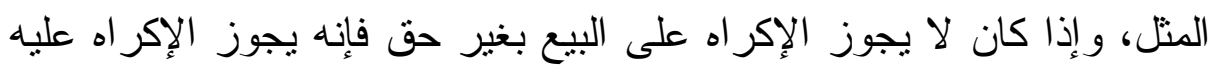

بحق"'

\section{الإطلب الثالث}

\section{الخيارات الشروية والاتفاقية ودورها في تدويم الائتمان في المعاهلات

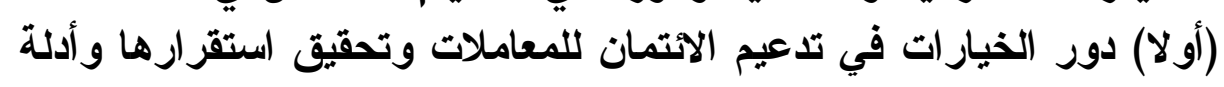

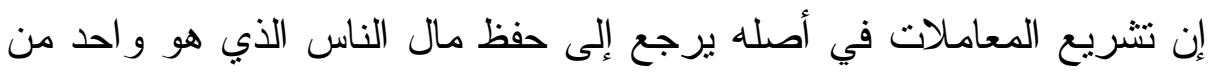

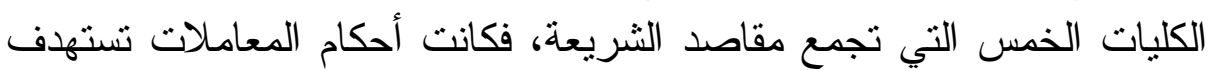
تحقيق هذا المقصد بمنع أكل المال بالباطل أو الاعتداء عليه بالسرقة و المطالبة بإنمائه، وشر عت الكثير من العقود المساعدة على تحقيق ذلك من بيع و اجارة

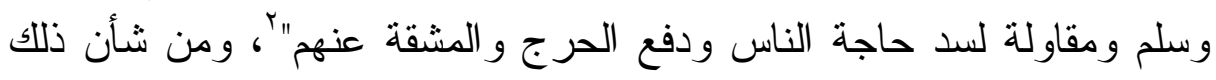

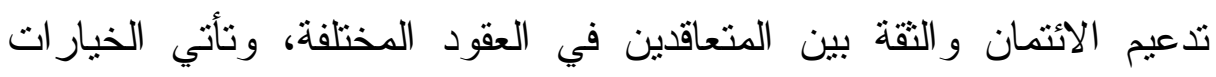

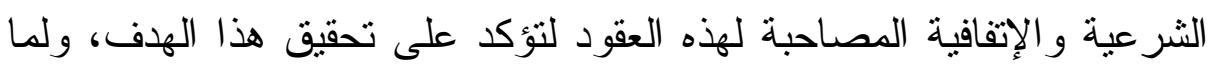

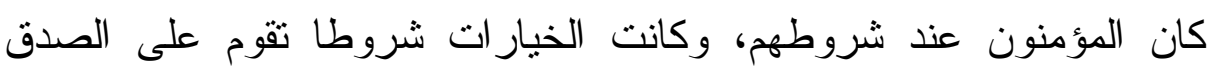

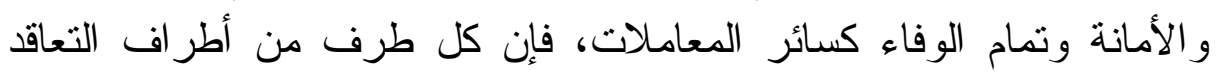

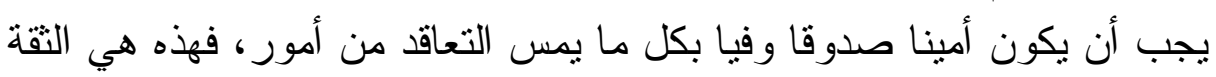
الحقة، و هذا هو ما به يكون الاستقر ار الحق للمعاملات.

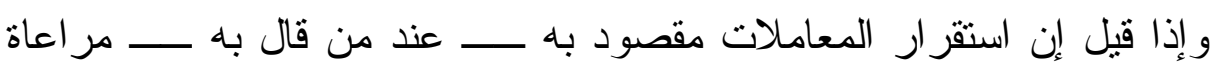

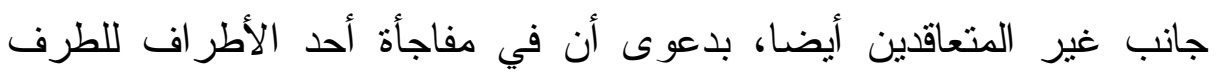

' الطرق الحكمية في السياسة الثرعية، للإمام بن القيم الجوزية، تحقيق محمد جميل

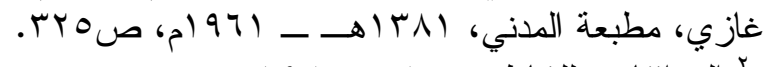

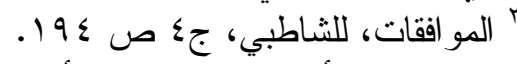

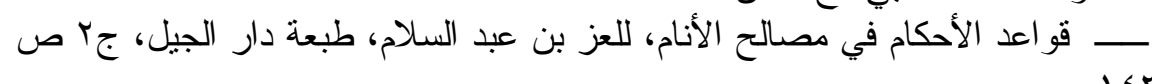
ـــــــمد عثمان شبير، المعاملات المالية المعاصرة في الفقه الإسلامي، طبعة دار النفائس، ص اب و وما بعدها. 
الآخر بالفسخ ما يؤدي إلى انعدام الثقة في المعاملات، فإنني أقول إنه ليس في

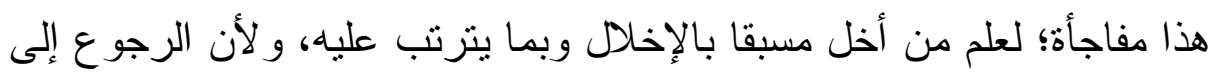

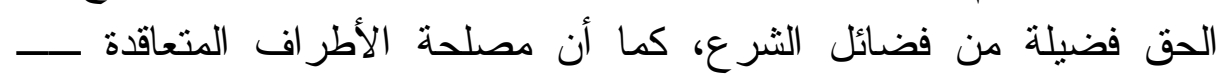

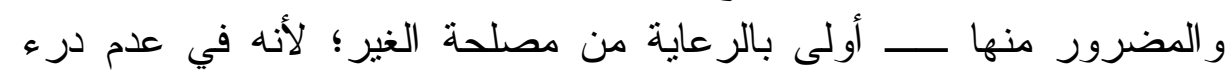

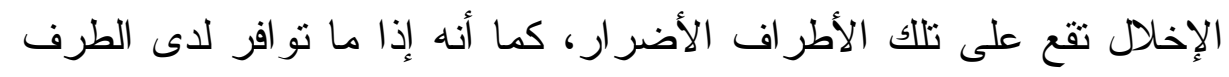

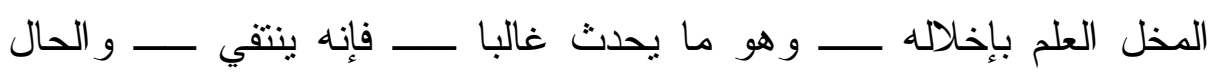

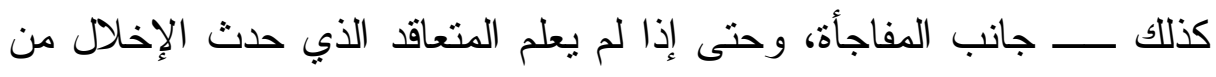
جانبه سبب الإخلال، ثم علم بظلم حاق بمن تعاقد معه بسببه، فإن إسلامه إلها

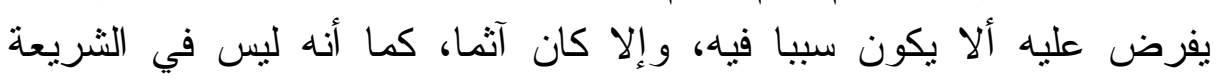

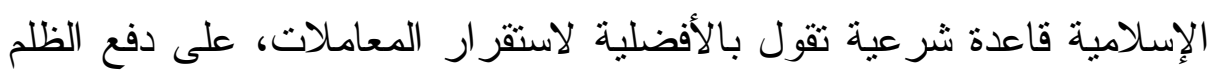

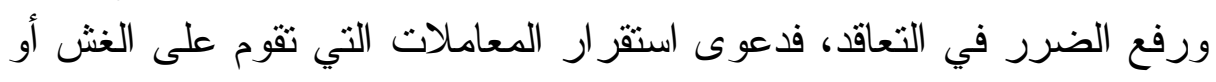

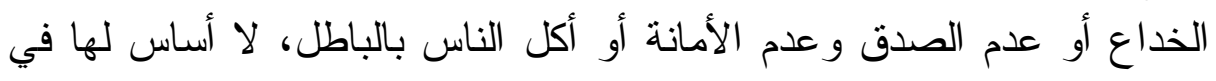

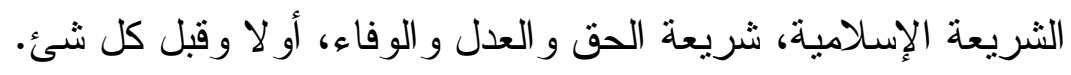

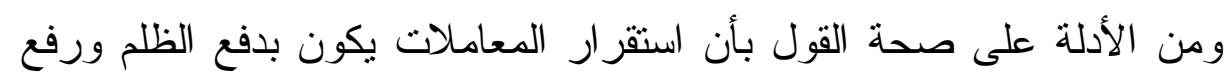

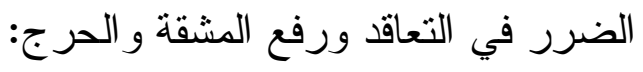

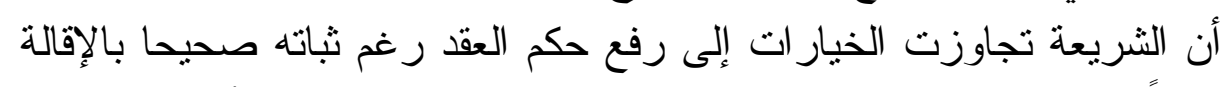

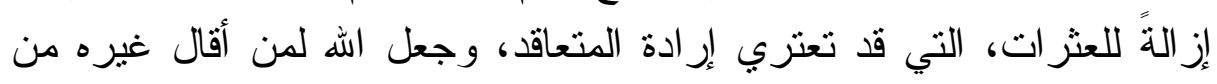

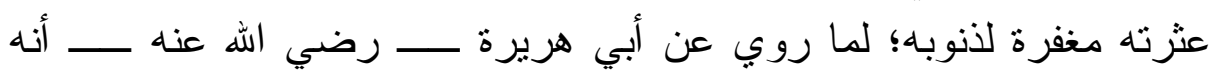
قال : قال رسول الله صلى الله عليه وسلم " من أقال مسلما بيعته أقال الله لهاء

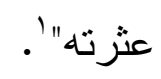
وخلاصة القول في هذا، أن فطرية الملكية، وتملك غريزة حب التملك، وحماية

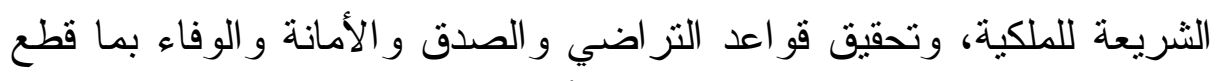

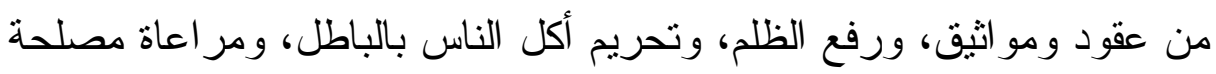

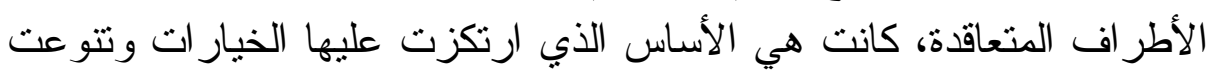

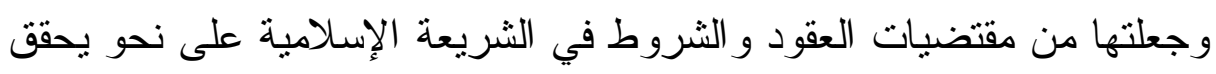

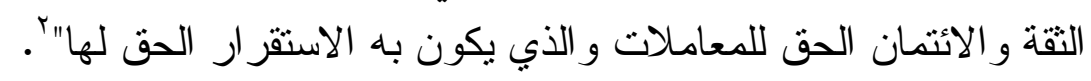

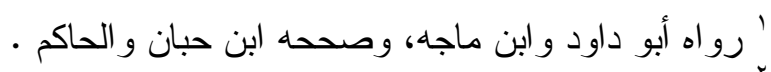

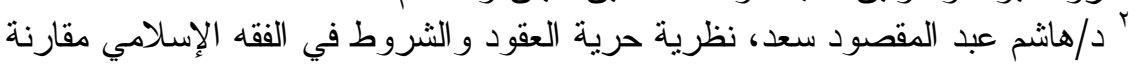

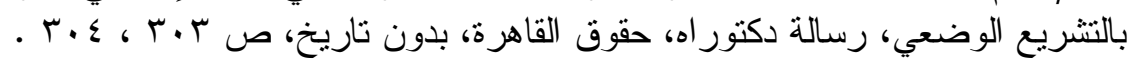


ثانيا : بعض الخيارات الشرعية والاتفاقية في الفقه الإسلامي"'

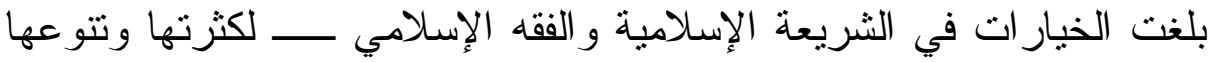

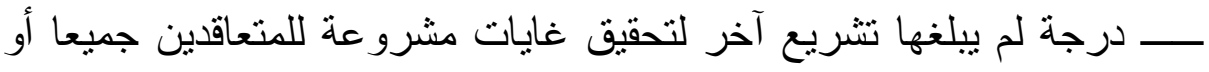
أحدهما، تحقق في مجموعها الثقة بين المتعاملين وتدعم الائتمان للمعاملات

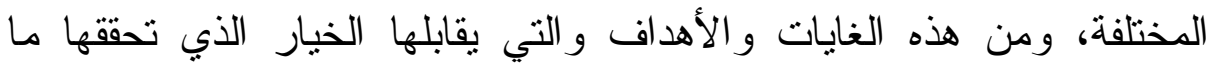
يأني: أــــأن يكون كل متعاقد على بينة من أمره، مفاضلا بين أوجه النفع، متلافيا

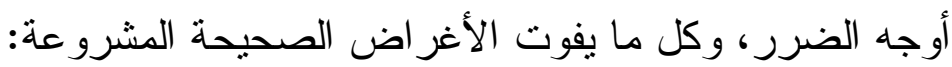

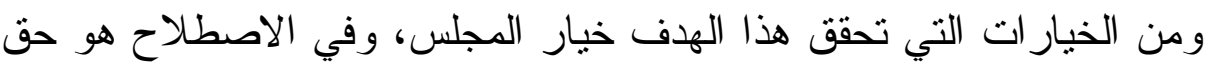

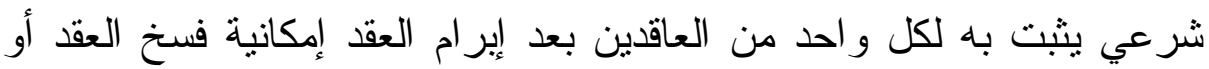

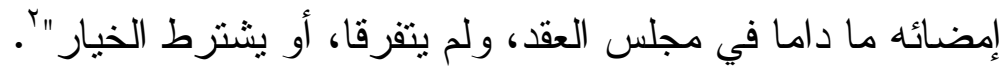

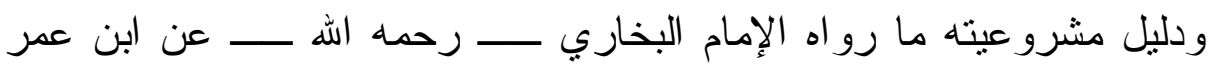

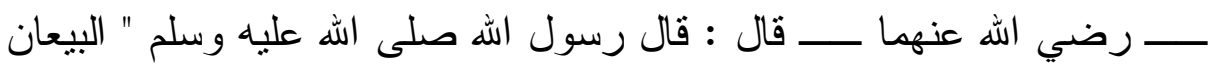
بالخيار ما لم يتقرقا. أو يقول أحدهما لصاحبه : اختر • وربما قال : أو يكون

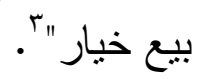

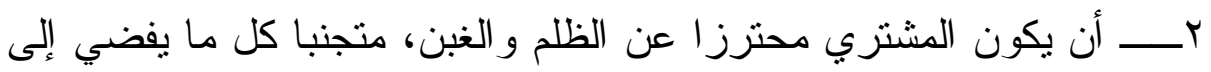

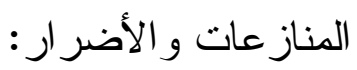

ومن الخيار ات التي تحقق هذه الغاية خيار تلقي الركبان، وهو اصطلاحا خيار

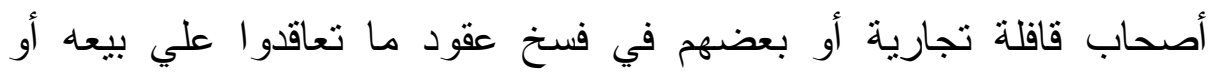

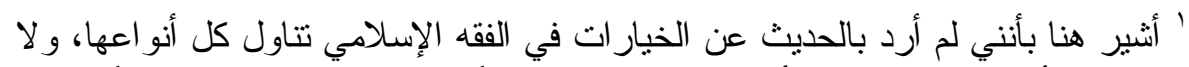

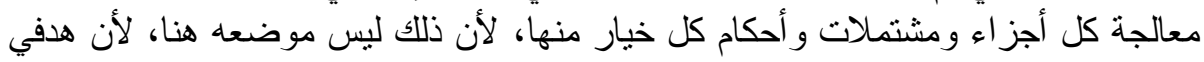

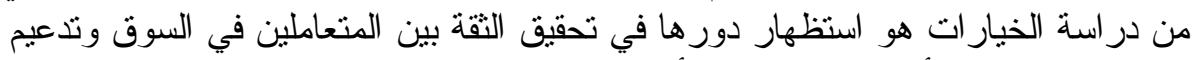

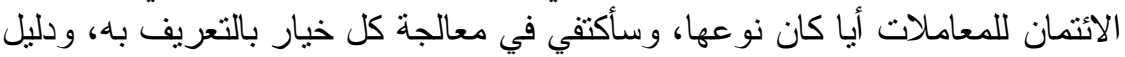

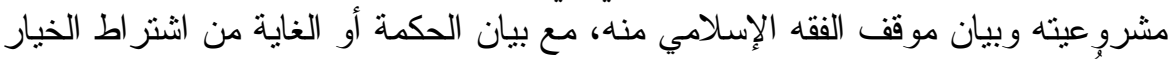

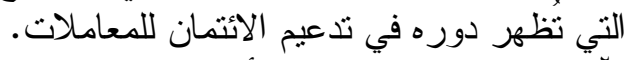

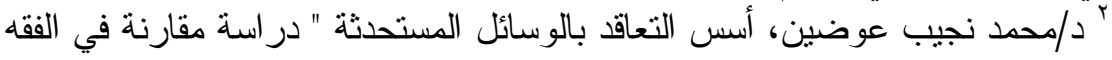

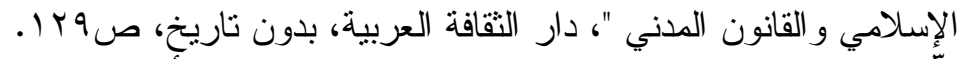

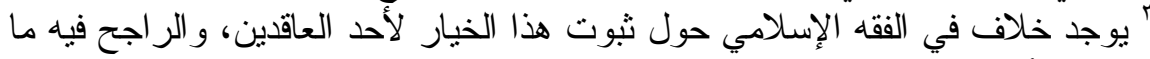

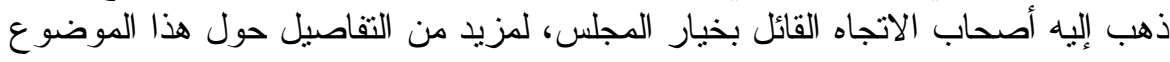

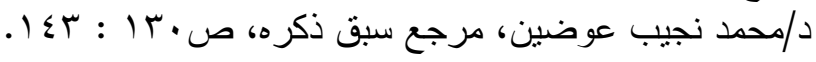


إمضائها، إذا ما تلقاهم خارج السوق بعض الناس، فاشترو ها منهم بثمن بخس، ثم وجدوا به أسعار بضاعتهم أكثز ارتفاعا، مما كان عليه سعر التعاقد.

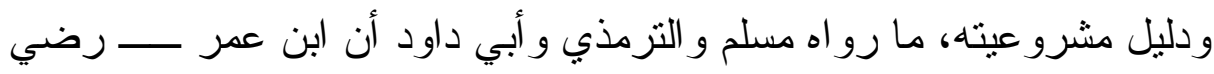

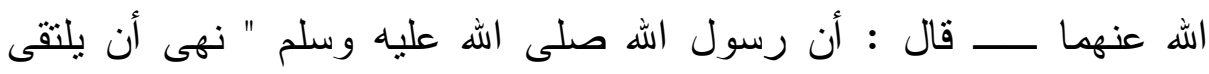

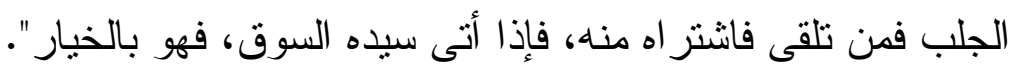

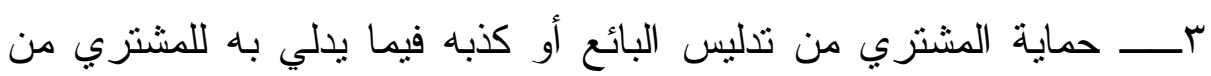

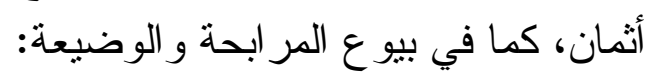
ومن الخيارات التي تحقق هذا الهدف خيار التغرير أو خيار العدول في المر ابحة و الوضيعة، و هو خيار فسخ العقد بسبب إخفاء حقيقة المبيع، و إظهاره

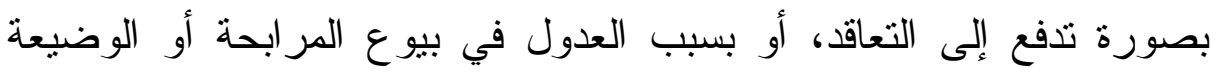
بسبب كذب المشتري و عدم أمانته في التعامل، و الغرر اصطلاحا اخفاء حقيقة

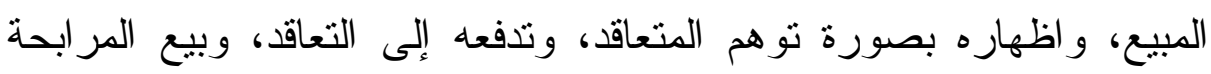

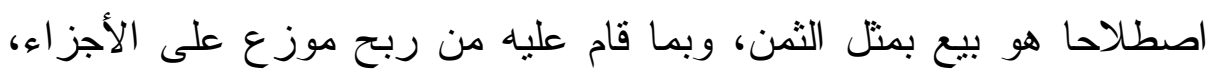

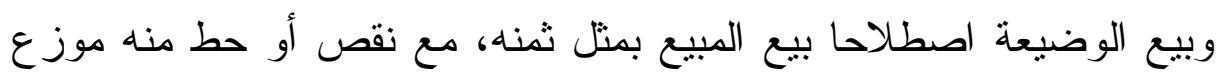

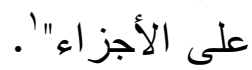

و لا خلاف بين فقهاء المسلمين في ثبوت خيار التغرير للمشتري، حيث أنه لما

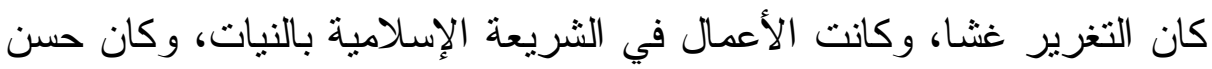
النية و الأمانة مطلب شرعي في المعاملات، فإن إيهام المتعاقد بغير الحقيقة تدليسا بقصد دفعه إلى التعاقد، وقيام العقد على ذللك التدليس و الوهم يثبت فيت خيار

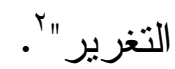

وفي بيوع المرابحة و الوضيعة فإن الثرع يقتضي إظهار الأثمان الحقيقية مضافا إليها جملة التكاليف المالية إن وجدت مع مر اعاة العرف في ذللك، وذللك

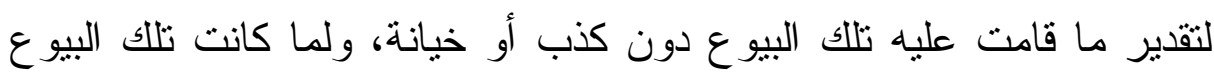

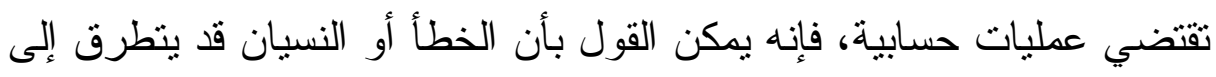

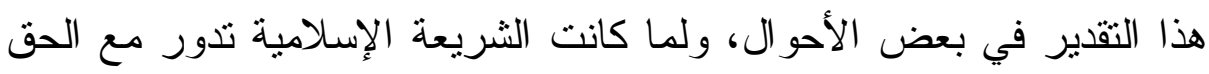

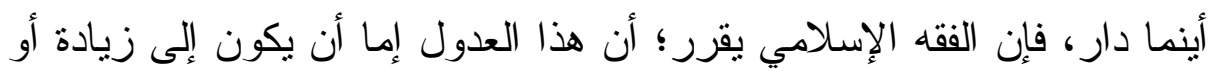

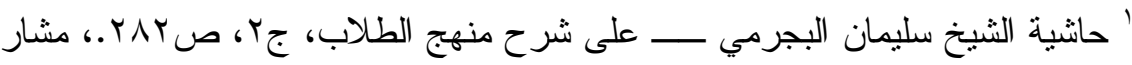

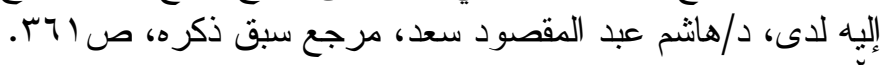

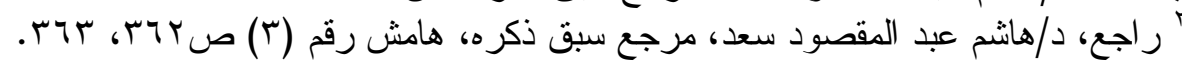


إلى نقصان، و إما أن يقام عليه الدليل أو ألا يقام، فإن كان إلى زيادة و أقيم عليه

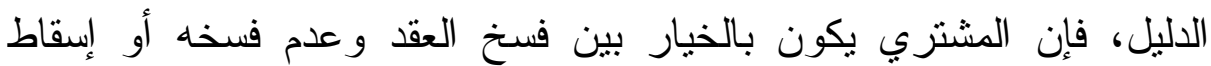

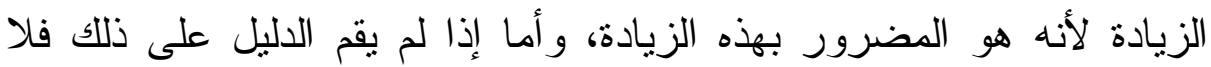

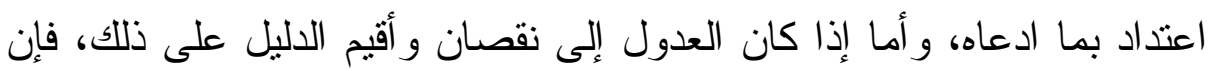

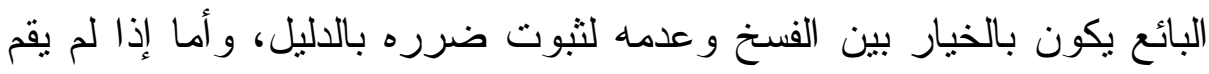

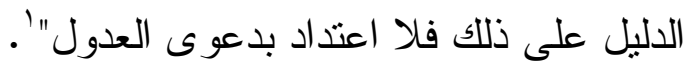

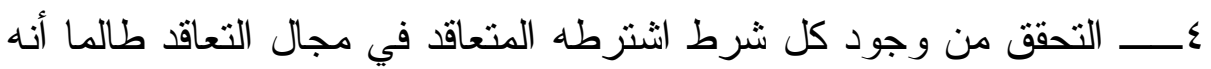
لم يحرم حلالا أو يحل حر اما، مستثر ا الفرص في التثبيت من التر اضي:

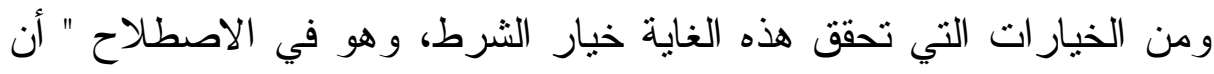

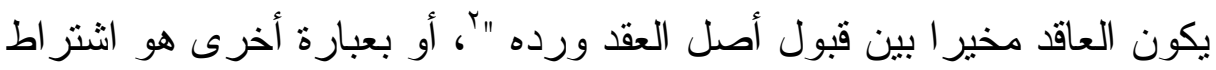

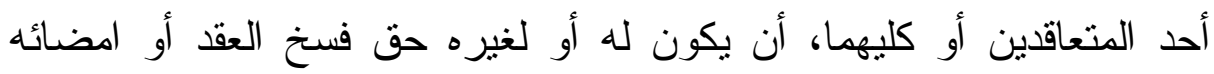

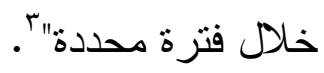
ودليل مشروعية خيار الثرط، ما ثبت من أن حبَّان بن منقذ الأنصاري كان

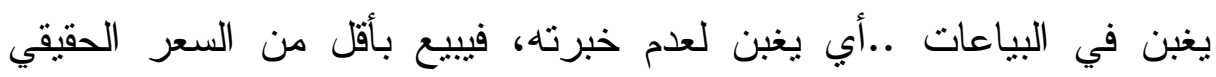
ويشتري بأكثر منه، وقد رفع أهله أمره إلى النبي صلى الله عليه وسلم فقال له

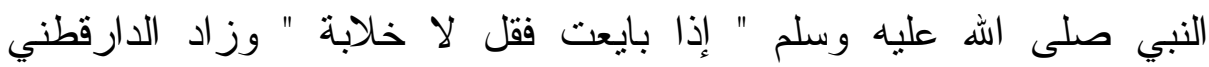
و البيهقي " ثم أنت بالخيار في كل سلعة ابتعتها ثناث ليال، فإن رضيتها لإنها

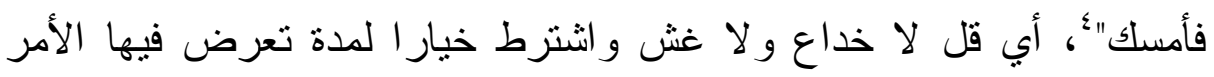

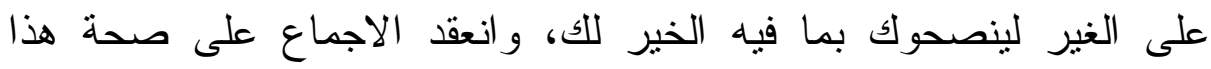

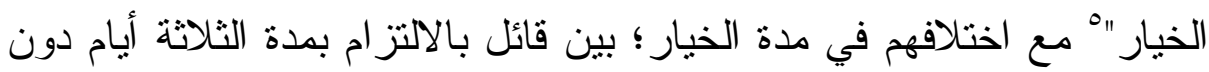

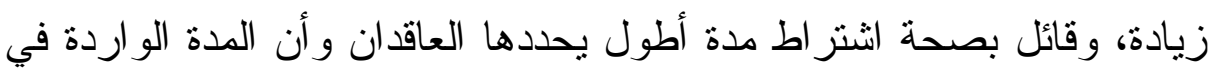

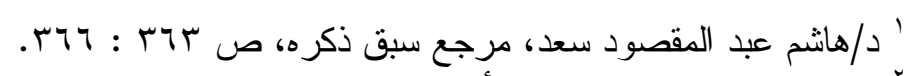

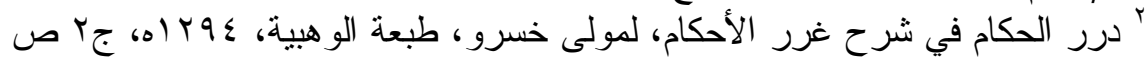

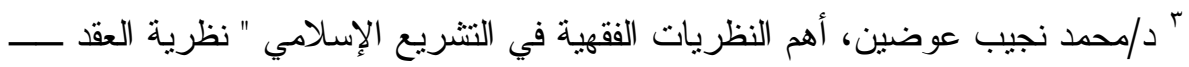

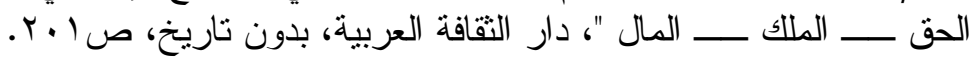
" شرح رياض الصالحين للإمام النووي، كتاب الأمور المنهي عنها، بارئ النهاب النهي عن الغش

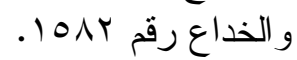

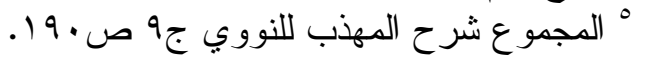


الحديث ليست على سبيل الإلز ام، وقائل بأن تحديد المدة برجع للعرف ووفقا

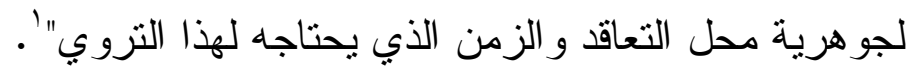

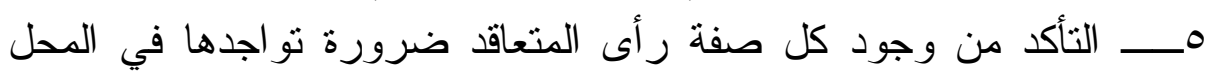
للاستفادة به على أكمل وجه:

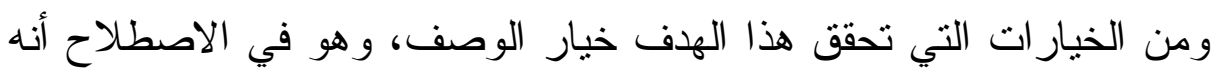

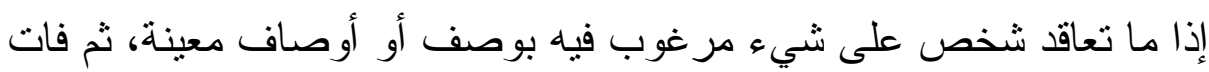

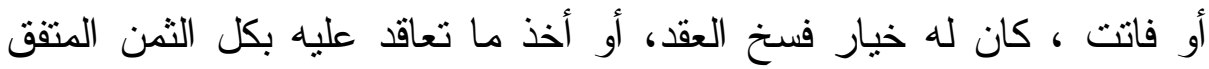
عليه"

وقد أخذ جمهور الفقهاء وغالب أهل العلم بخيار الوصف، وبرر الفقيه ابن

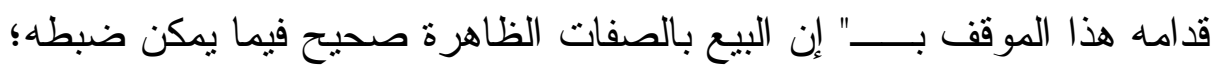

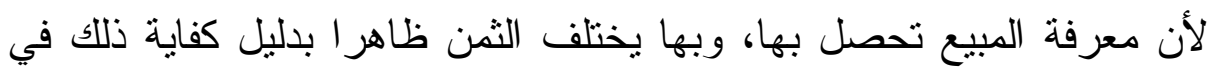

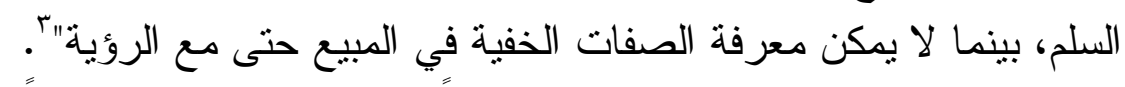

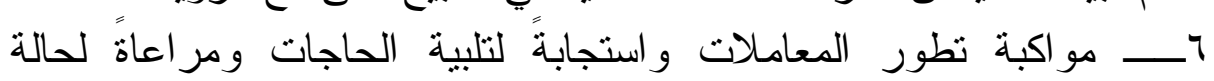
الضرورة التي قد تدفع إلى التعاقد على شيء غائب:

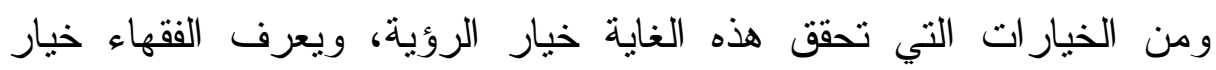

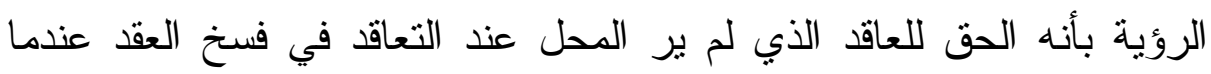

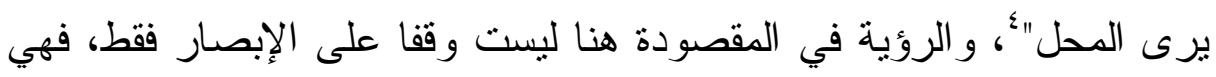

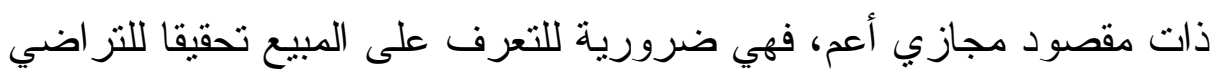

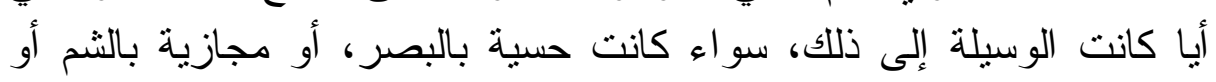
بالتذوق أو بالحس.

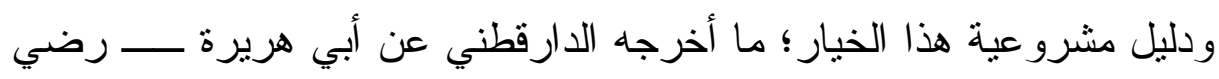

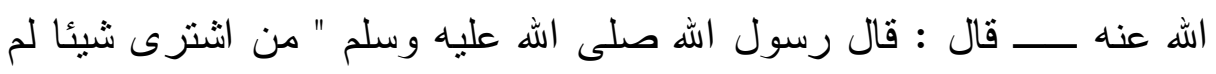

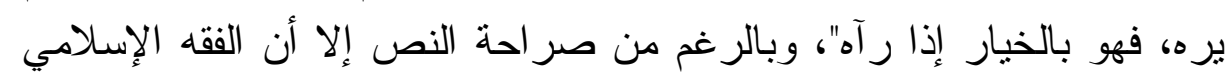

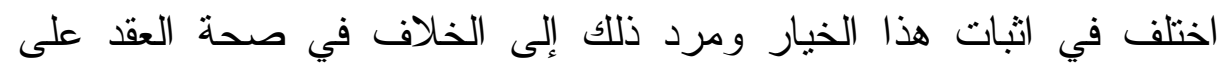

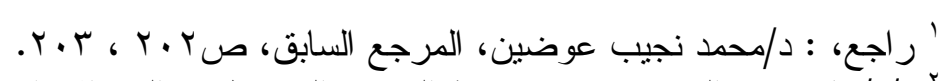

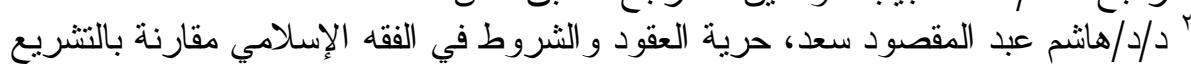

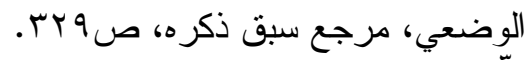

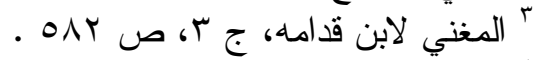

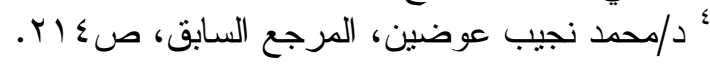


الأشياء المعينة الغائبة دون رؤيتها أم لا، فمن رأى منهم أن العقد غير صحيح

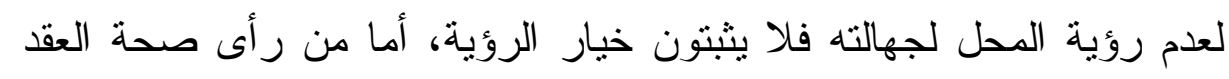
على الثيء الغائب المعين المحدد ولم تسبق رؤيته فهم يثبون خيار الرؤية في فئي

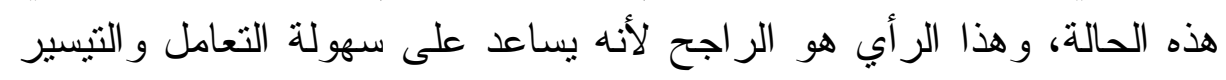

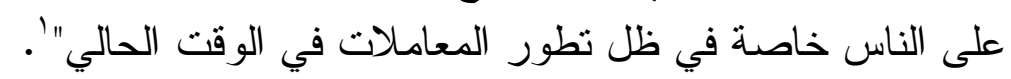

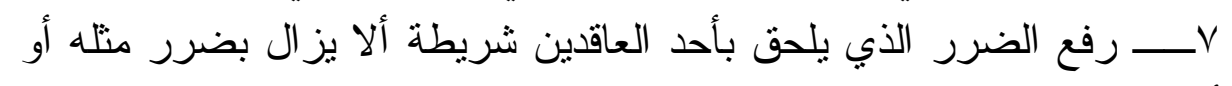
أثند منه:

ومن الخيارات التي تحقق هذا الهدف خيار تفريق الصفقة، وهو في

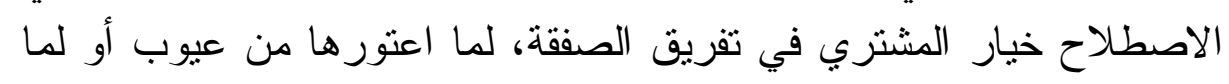

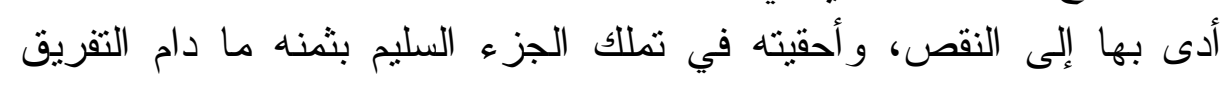

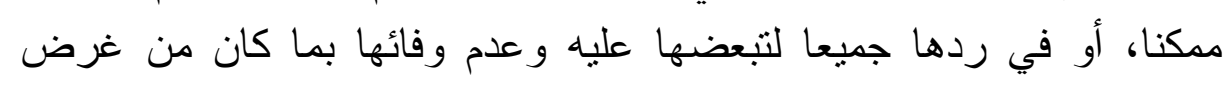
امتلاكه لها.

و الفقهاء متفقون على أنه ما دام أن محل الصفقة يقبل التقرقة فإنه يجوز ذلك

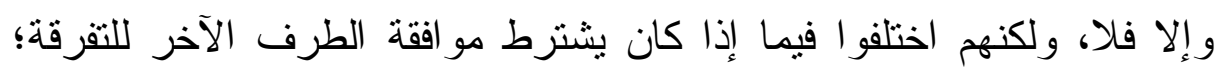

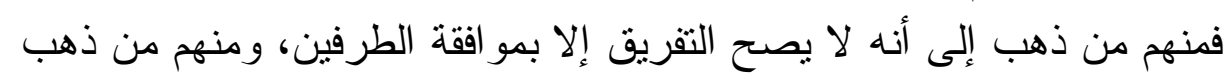

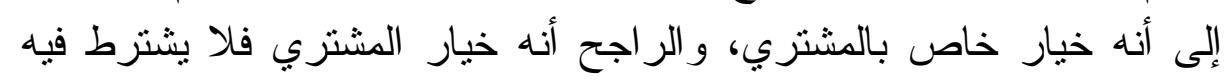

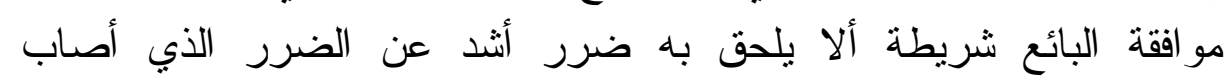

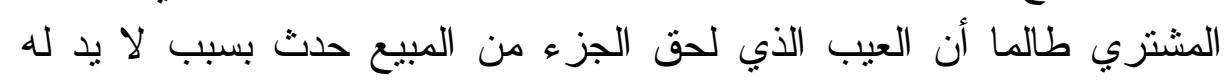

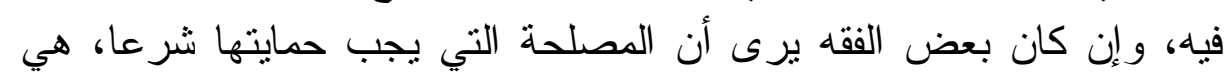

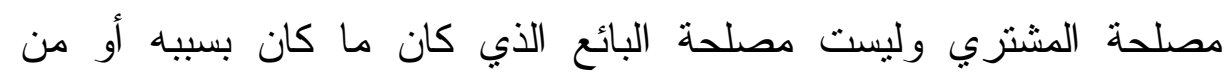

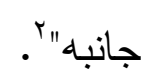

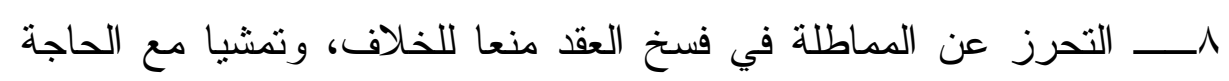
و الفطرة الإنسانية:

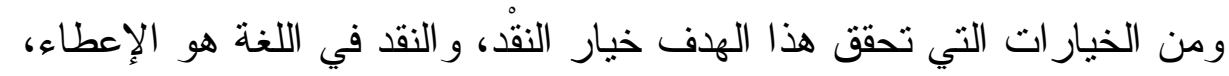

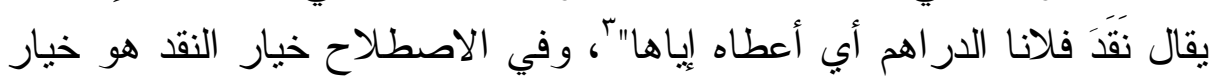

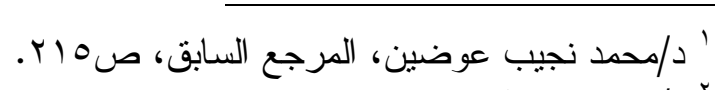

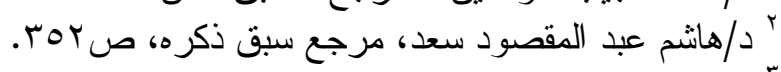

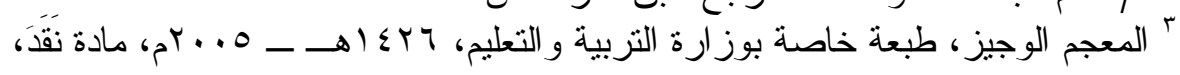
ص94 
فسخ المشتري العقد بعدم نقده الثن للبائع خلال ثلاثة أيام، أو خيار البائع في

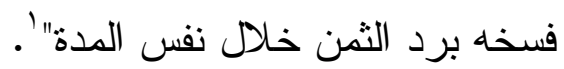

وللفقه الإسلامي بشأن خيار النقا اتجاهين؛ الأول برى جدى جوازه استحسانا

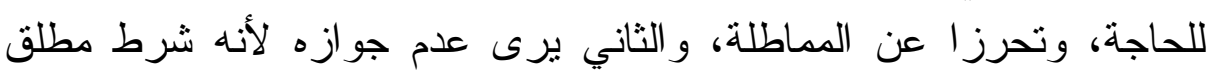

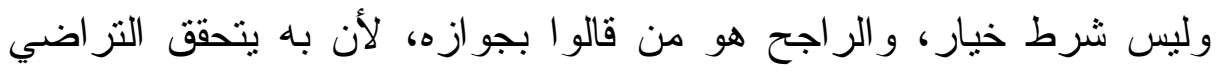

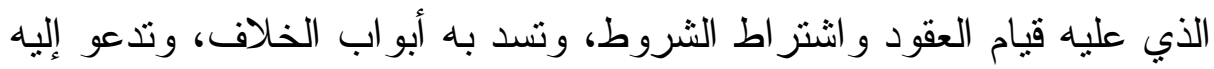

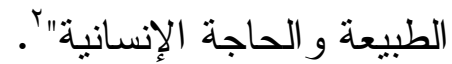

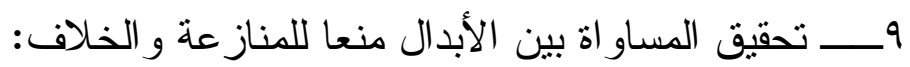

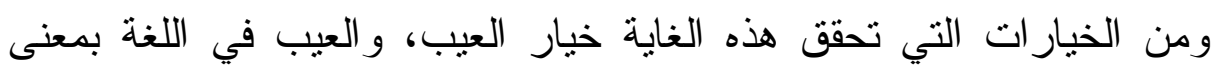

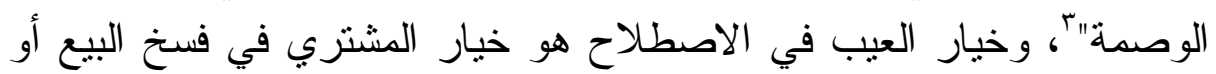
امضائه، لاطلاعه على عيب أو أكثز من العيوب التي يتعارف عليها التجار

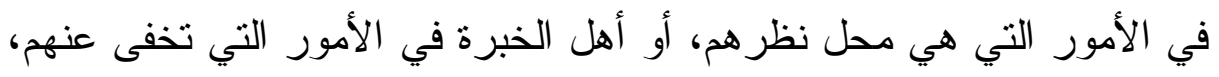
وتكون قد حدثت عند البائع، ولم يرها المشتري هند هين الأن البيع ولا لا عند القبض" (

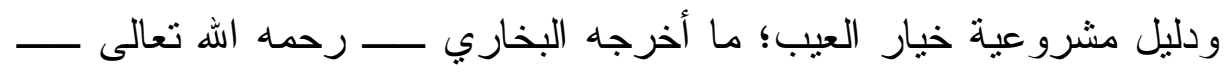

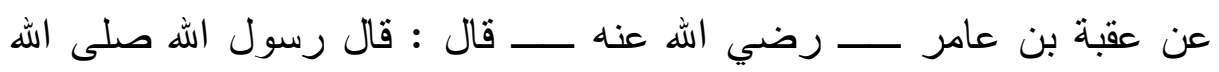
عليه وسلم " لا يحل لامرئ مسلم يبيع سلعة يعلم أن بها داء، إلا أخبر به".

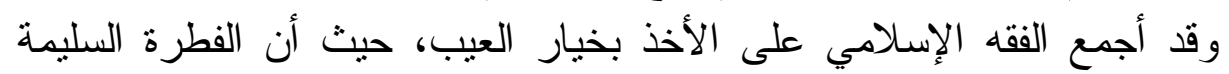

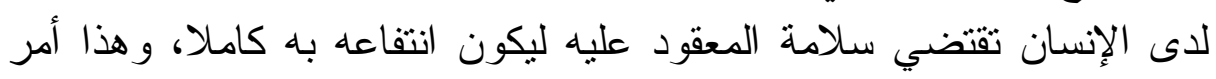

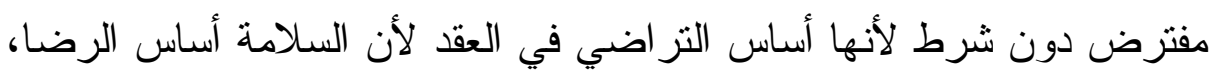

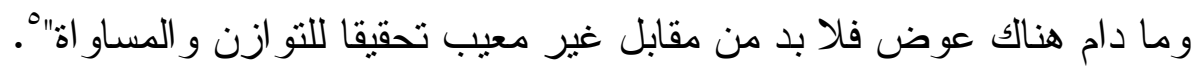

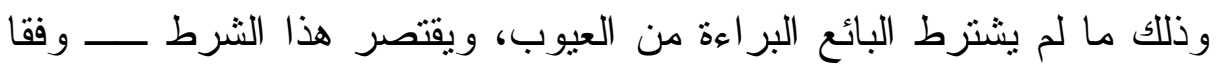

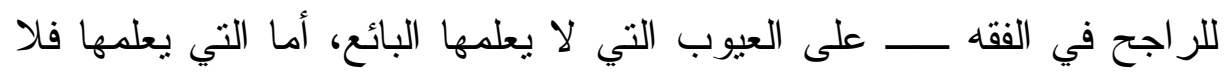

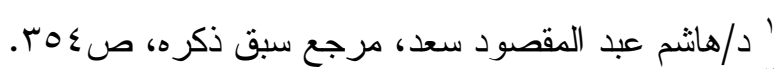

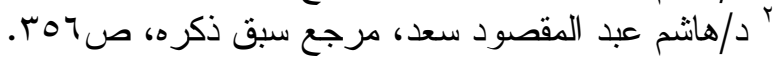

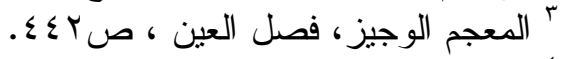

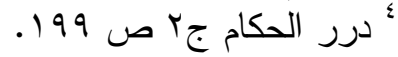

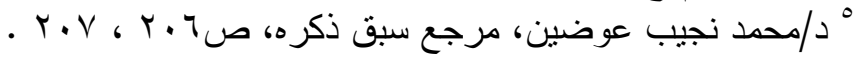


يجوز اثتزر اط البراءة منها لأن كتمانه لها يخالف النص الثرعي وهو أمر

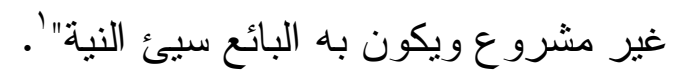

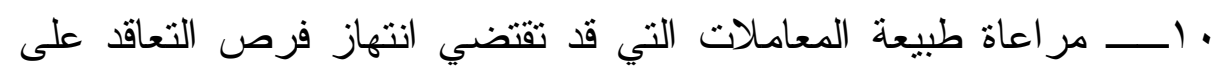
نحو بحقق مصلحة المشتري خشية وقو عه في المشاق و الأضر ار :

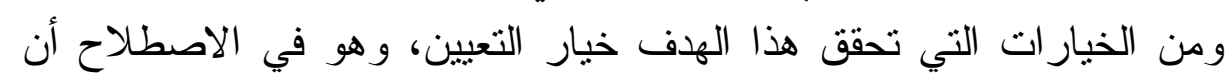
يثتري المرء أحد شيئين أو ثالثة، على أن بعين أبا شاء" ، ويرى بعض الفقه أنه لا يوجد مبرر لتقييد محل خيار التعيين بثلاثة الأثياء الواردة بالتعريف

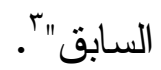

و عن موقف فقهاء الثريعة الإسلامية من خيار التعبين، فكان لهم اتجاهان؛ الأول ذهب إلى عدم جوازه لأنه بيع عين مجهولة، وأن فيه غرر من غير حاجة، و الثاني ذهب إلى جواز خبار التعبين استحسانا لدفع الغبن عمن اثترط له، ليختار ما هو الأرفق و الأوفق، و الحاجة إلى ذلك متحققة؛ لأنه قد يحتاج إلى اختيار من يثق به، أو من يشتريه له، كما أن البائع لا يُمَكِّه من الحمل

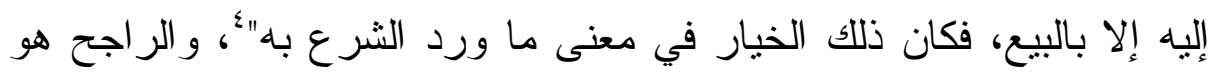

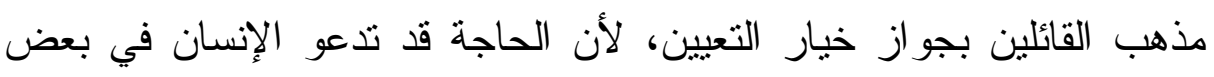
الأحيان إلى اثتر اط ذلك الخيار ، لما للمعامحات من طبيعة قد تقتضي انتهاز فرص التعاقد، وقد يؤدي عدم جواز هذا الثرط إلى الوقوع في المشاق و الأضر ار ، و عدم تحقيق المصالح. وبنظرة جامعة لكل تلك الخيار ات سو اء الثر عية منها أو الاتفاقية، يمكن القول بأنها تعد تطبيقا لبعض القو اعد الفقهية المستمدة من أحكام الثريعة الإسلامية التي وضعها فقهاء الثريعة الإسلامية، و التي تدل على سعة الثريعة الخالدة ورفع المشقة و الحرج، ومدى مر اعاتها لتحقيق المصالح ودفع المضار ، ومن ومن ونهي

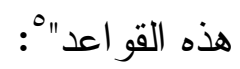

الضرر يز ال، توجب رفع الضرر و إز الته.

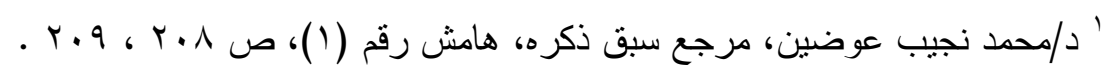

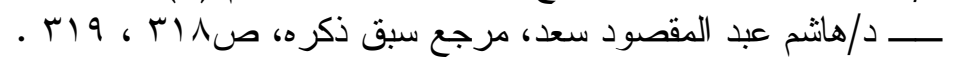

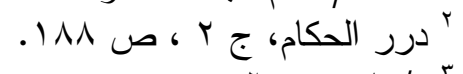

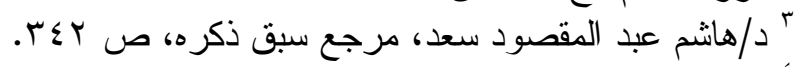

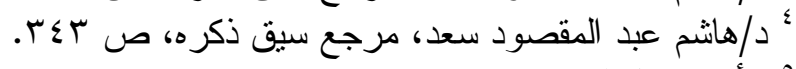

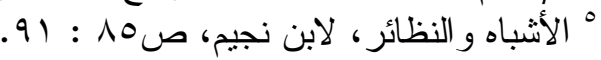


ب ــــا جاز لعذر بطل بزو اله، تتفي الجواز مع زو ال الضرر.

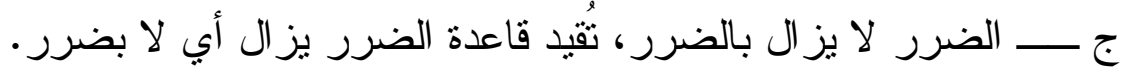

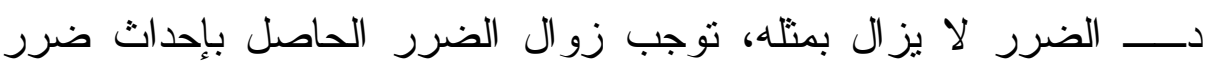

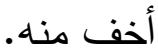

هــــالضرر الأثند يز ال بالضرر الأخف، تطبيق لقاعدة الضرر لا يزال بمنظه.

وـــــإذا تعارضت مفسدنان روعي أعظمها ضرر ا بارتكاب أخفهما. ز زــــــ درء المفاسد مقدم على جلب المصالح.

وبنظرة تحليلية موضوعية لتلك الخيار ات، يمكن القول بأنها جميعها تبث روح التقة والتعاون بين المتعاملين في السوق، وتنفي عنهم كل ما يؤدي إلى فئل الخلاف و الثقاق و التباغض، بدرجة أكثر فاعلية و أكثر عدلا وقسطا عما توفره

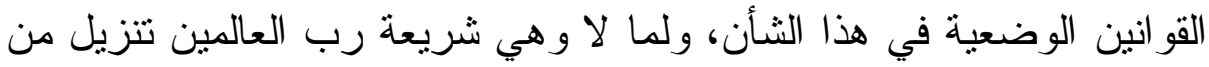
حكيم خبير بما يصلح لعباده في دنياهم و أخر اهم، وهذا من شأنه في النهاية لثانية

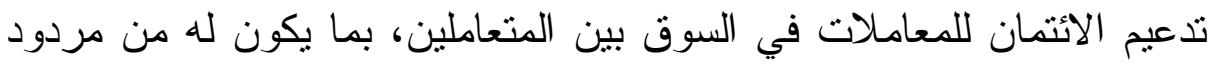
إيجابي على الاقتصاد الوطني.

\section{الإطاب الرابع بعض صور تدخل الدولة لتدعيم الائتسمان في المعاهملات}

(أولا) : الحسبة

الحسبة ولاية في الإسلام، وجميع الولايات الإسلامية إنما مقصودها الأمر

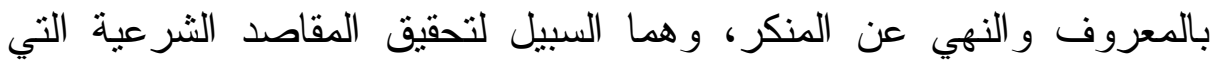

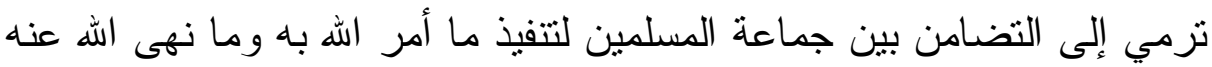

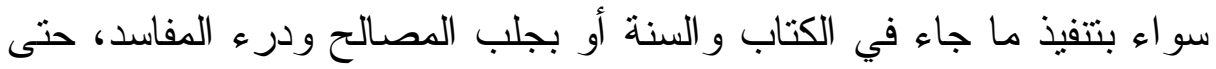

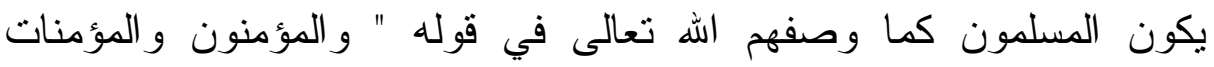

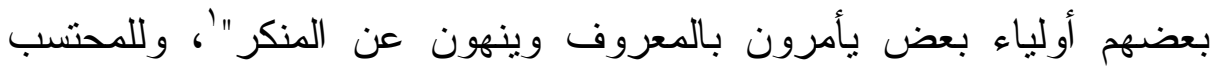

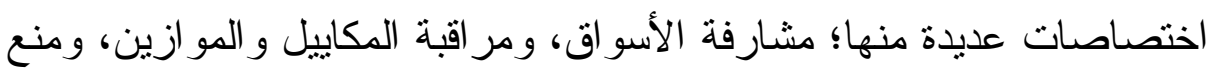

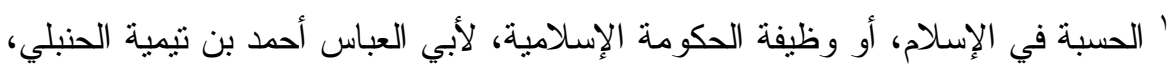

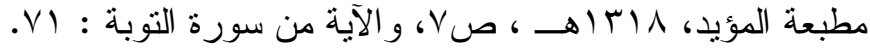

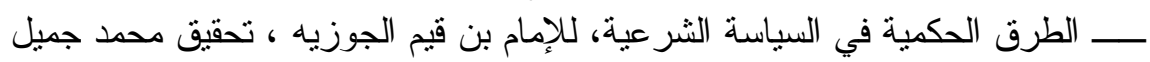

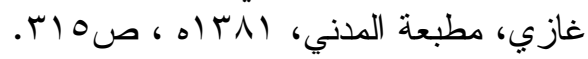


الناس من الازدحام في الطرقات، ومراقبة أهل السوق في مبيعاتهم

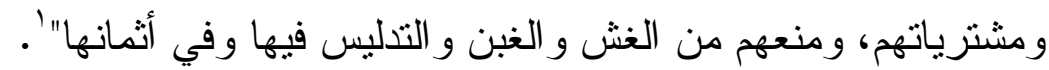

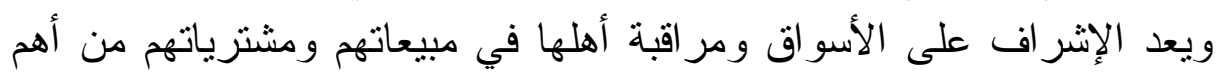
و واجبات المحتسب، لدعم آداب التعامل الإسلامي بين الناس وتثتبيت أركانه،

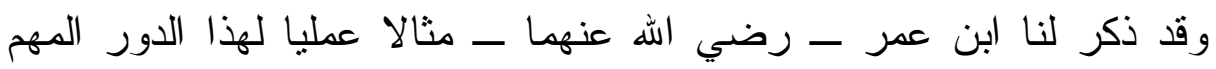

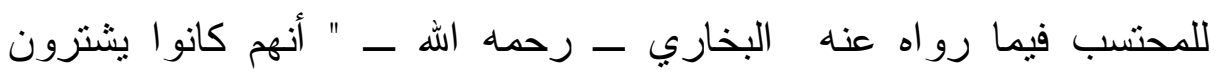

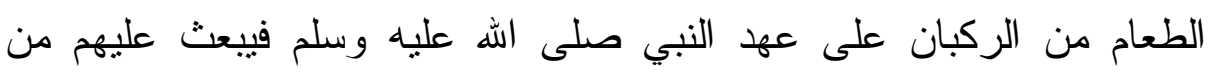
يمنعهم"، أي أن النبي صلى الله عليه وسلم كان يبعث المحتسب ليمنع التجار من مثل هذا الثراء حتى يتيح الفرصة للبدو أن يحضروا إلى السوق ويعرفو النها

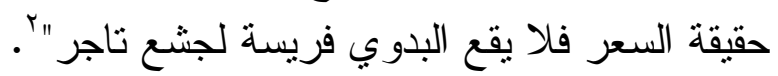

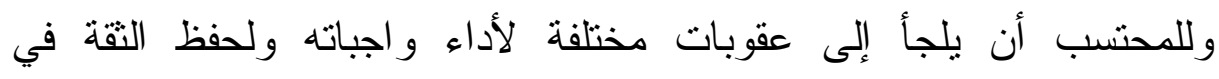

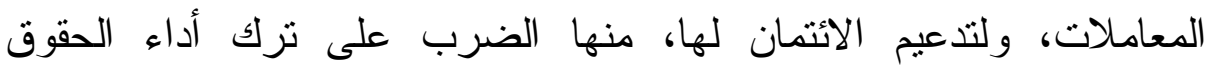

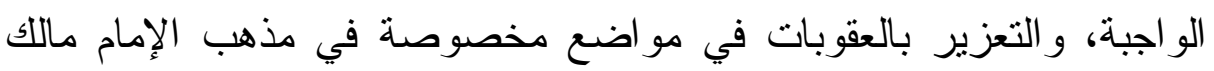

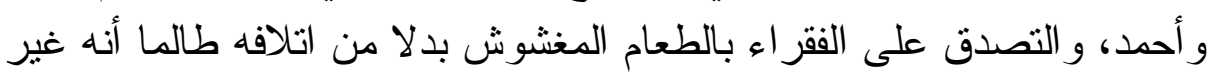

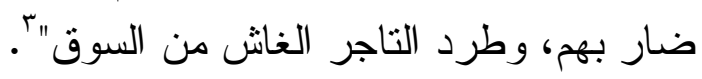
(ثانيا) التسعير بهم وطري التسعير في أعر اف التجارة المعاصرة يقصد به أمران : الأول: تحديد أسعار

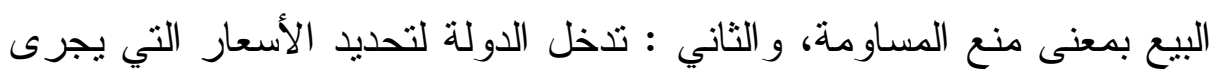

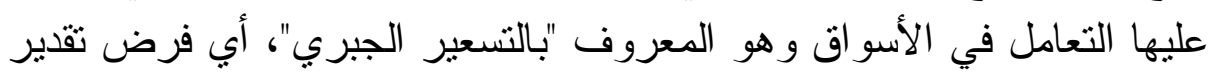

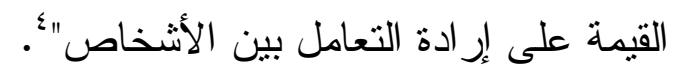

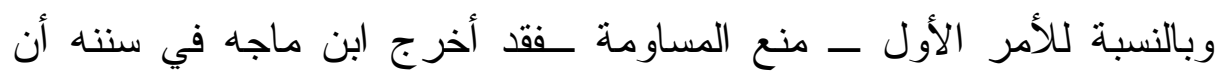

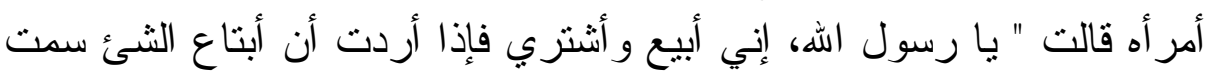

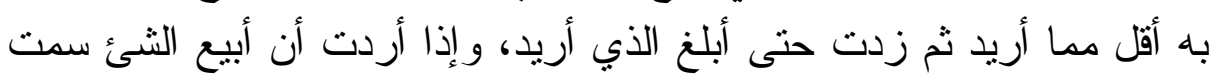

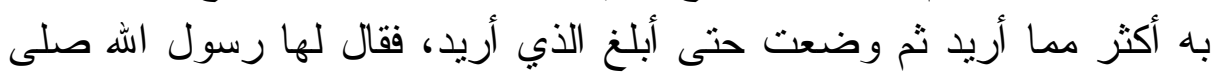
الله عليه وسلم : لا تفعلي، إذا اردت البيع و الثر اء فاستامي بما تريدين".

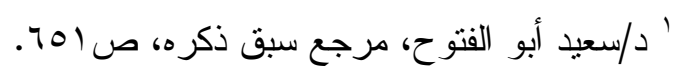

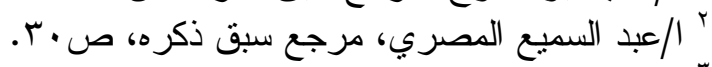

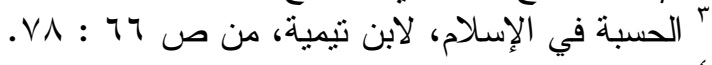

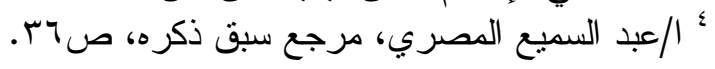


ففي منع المساومة توفير للجهد الضائع فيها وما تجره من خلافات ومشاكل

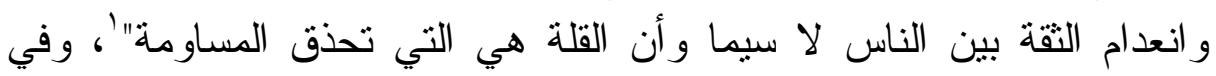

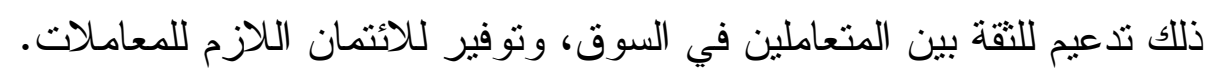

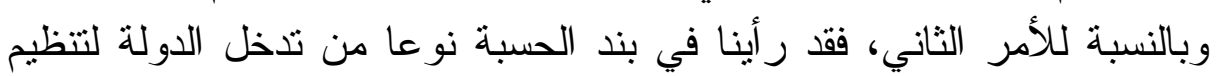

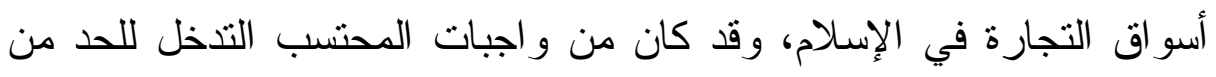

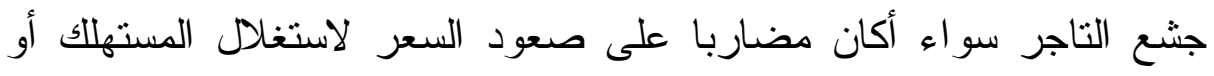
مضاربا على النزول للإضر ار بالمنتج.

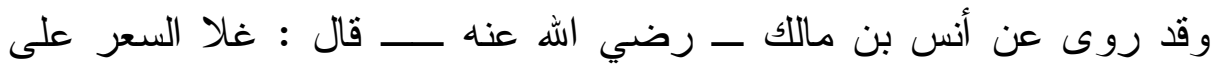
عهد النبي صلى الله عليه وسلم فقال الناس : با رسول الله غلا السعر فسعِّر لنا، فقال رسول اله صلى الله عليه وسلم " إن الله هو الخالق القابض الباسط فله الرازق المسعر، و إني أرجو أن ألقى ربي وليس أحد منكم بطلبني بمظلمة لإنة

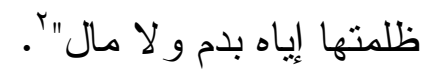
وفي تفسير هذا الحديث انقسم الفقه الإسلامي إلى فريقين" آل يذهب الأول منهما

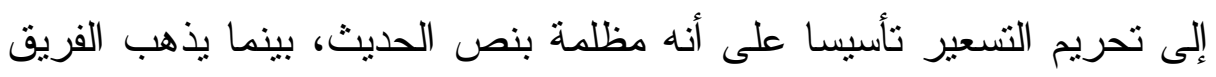

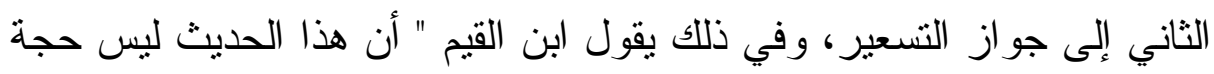

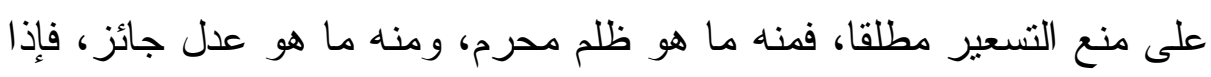

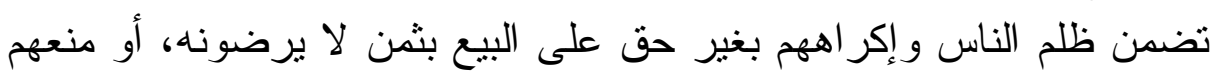

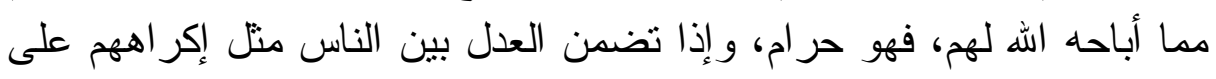

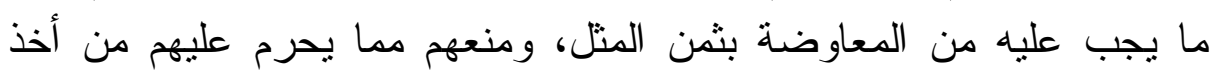

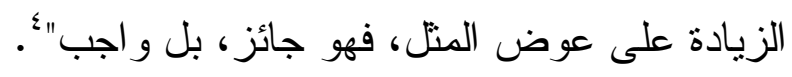
إذن يمكن القول أن الأصل في الإسلام هو حرية فئ السوق، أبي ترك تحديد

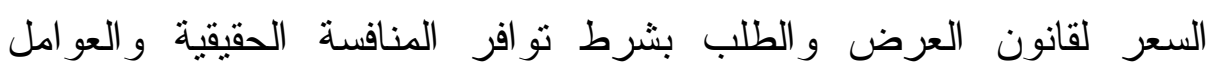
الطبيعية لهذا القانون وبشرط :

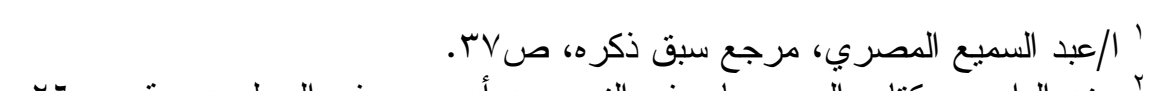

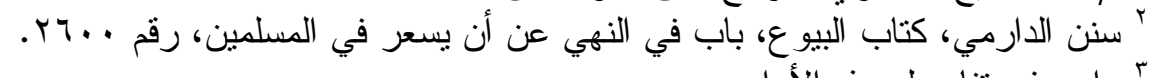

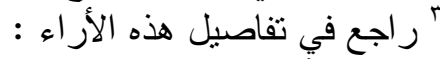

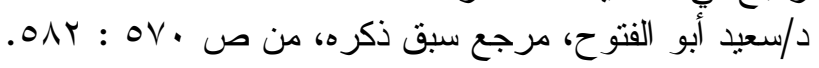

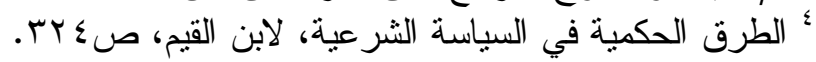




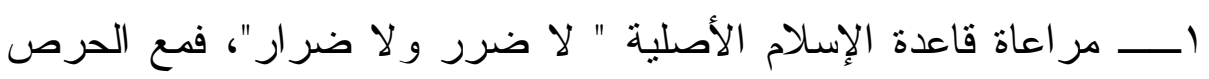

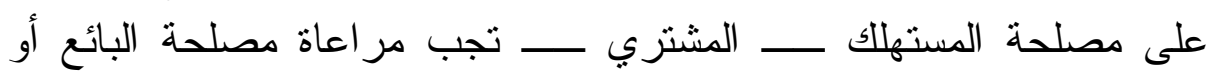
المنتج

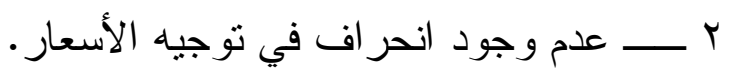

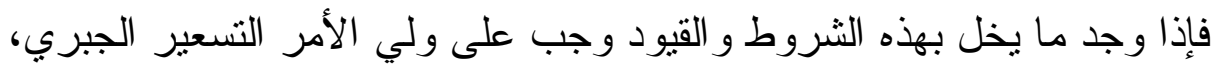

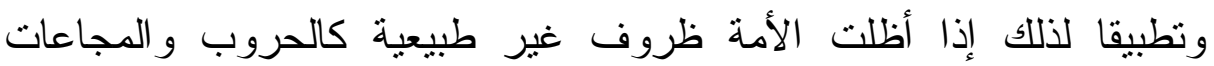
و المظاهر ات و الإضر ابات، أو وضح لولي الأمر وجود انحر افات في السوق،

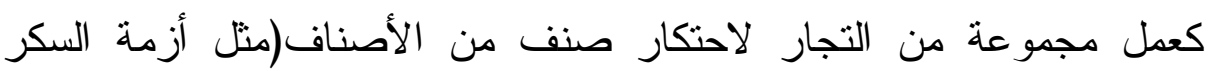

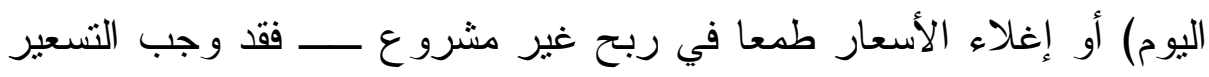

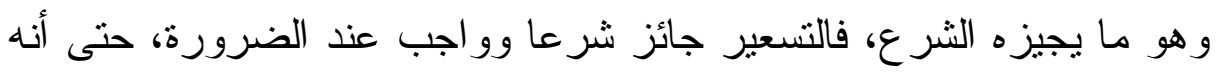

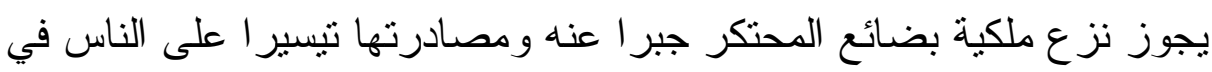

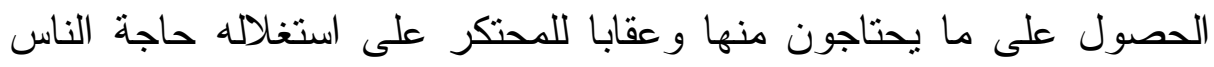

\section{(ثالثا) توقيع عقوبة على المدين المماطل المستطيع}

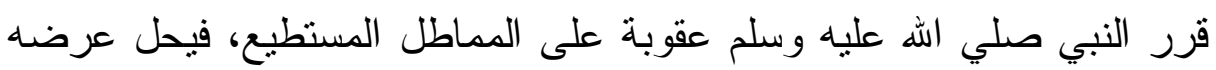

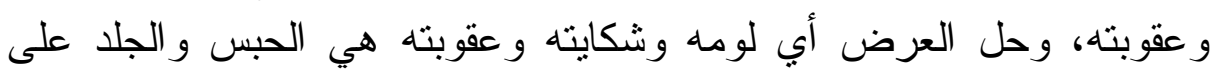

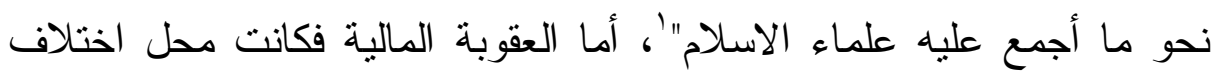

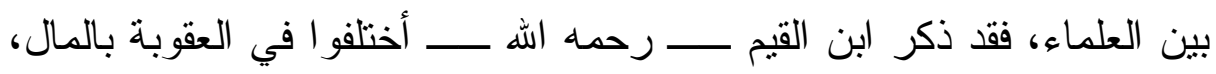

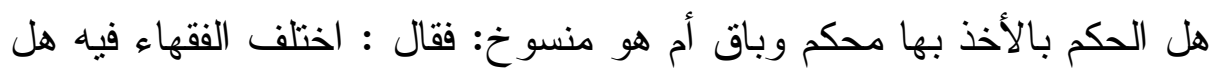
حكمه منسوخ أو ثابت، و الصواب أنه يختلف باختلاف المصالح ويرجع فئ فيه

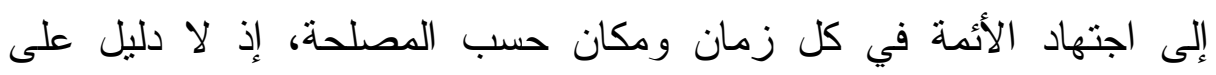

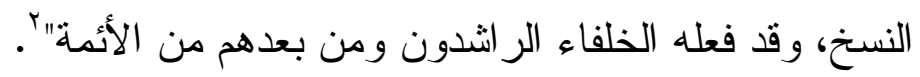

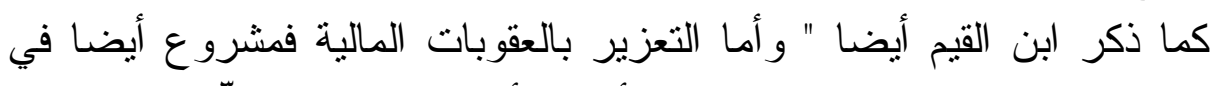

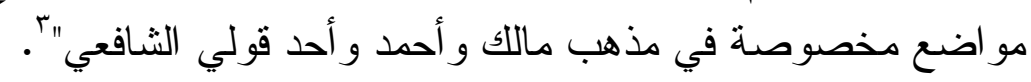

' الثيخ/عبد الله بن سليمان بن منيع، بحث في أن مطل الغني ظلام يحل عقوبته و عرضها،

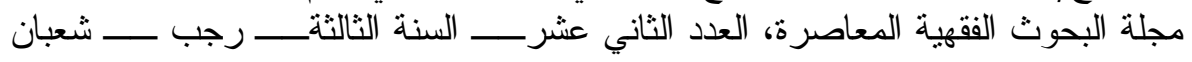

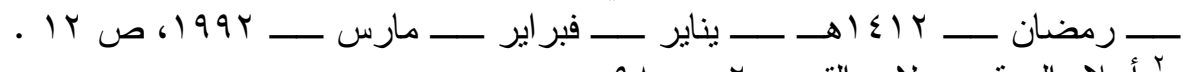

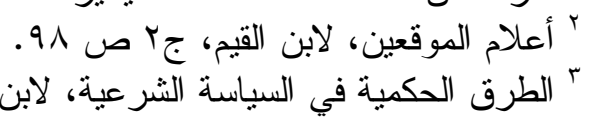


و إن تضمن عقد الالتز ام بالحق شرطا جز ائيا لقاء المماطلة و الليّ بقدر فو ات

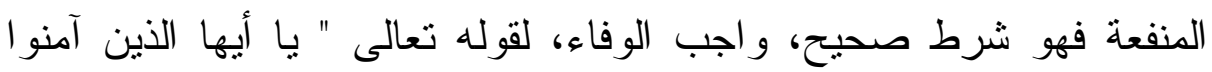

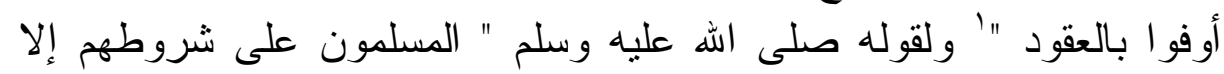

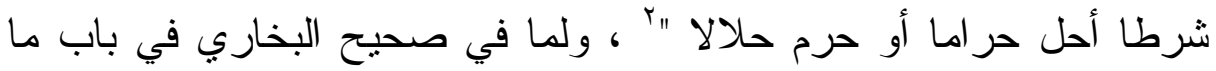
يجوز من الاشتراط والثتيا في الإقرار و الثروط التي يتعارفها الناس بينهه،

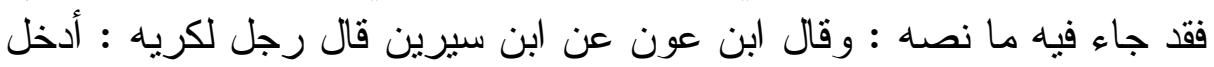

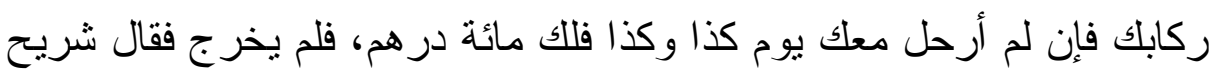

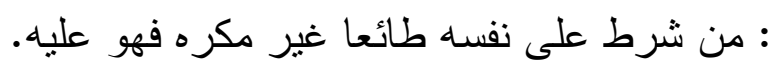

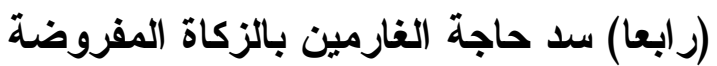

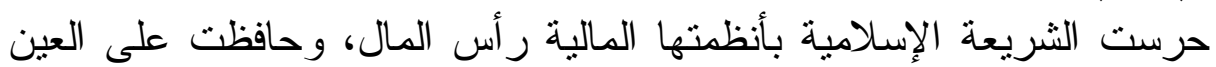

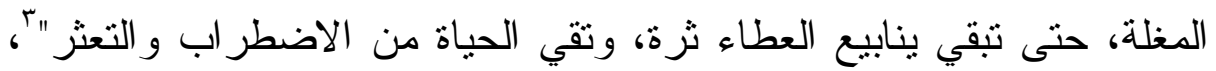

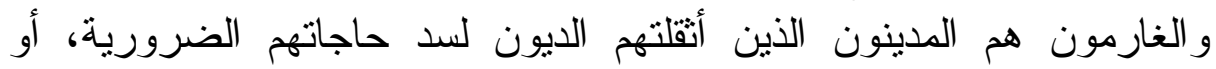

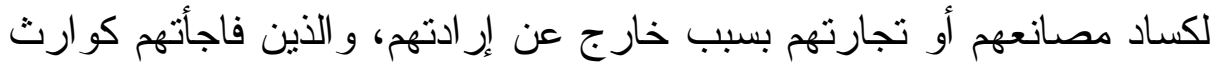

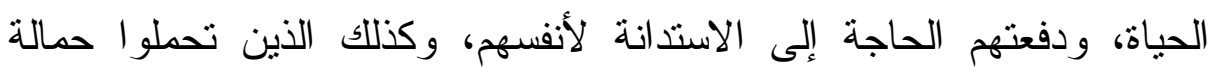

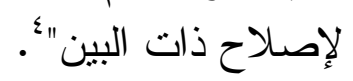

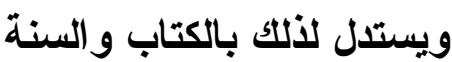

إـــالدليل من الكتاب : قوله تعالى " إنما الصدقات للفقر اء و المساكين و العاملين عليها و المؤلفة قلوبهم وفي الرقاب و والغارلهي تولين وفي سبيل الله وابن السبيل" - و العاين

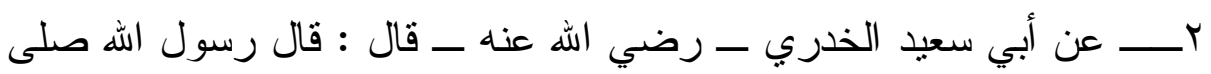

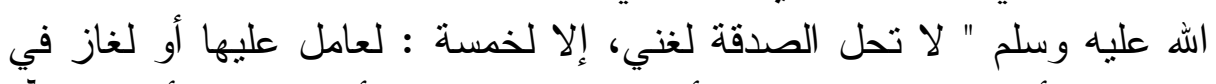

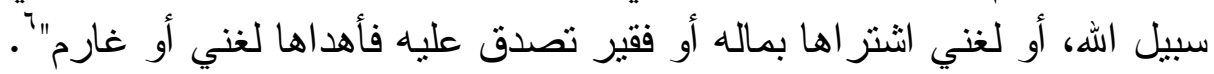

$$
\begin{aligned}
& \text { ' سورة المائدة، الآية : } 1
\end{aligned}
$$

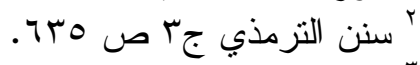

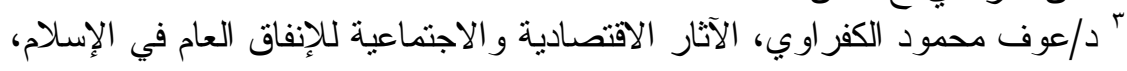

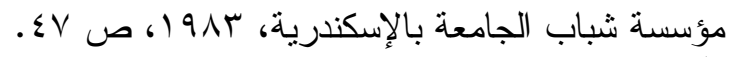

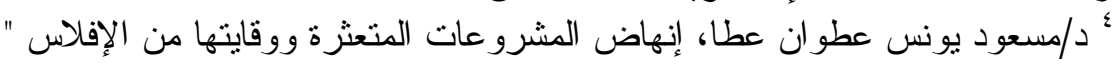

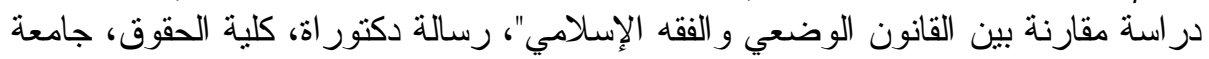

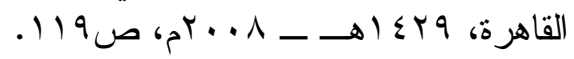

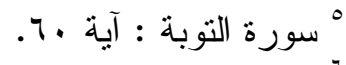

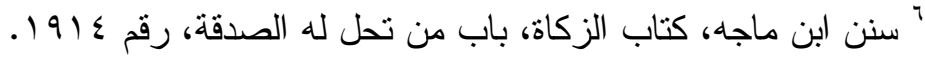




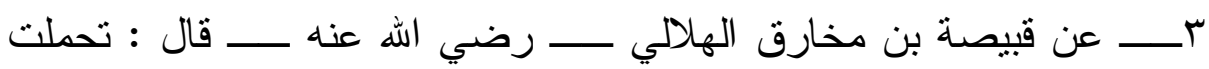

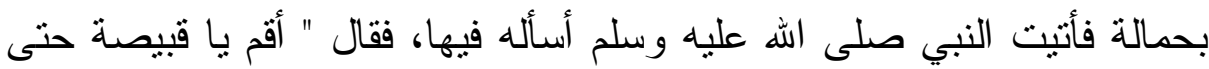

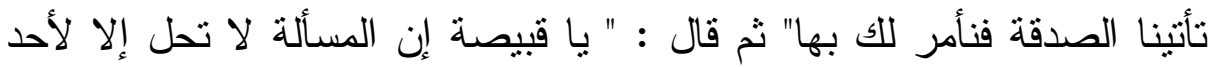

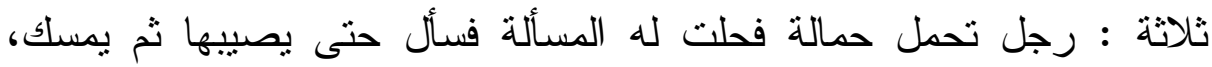

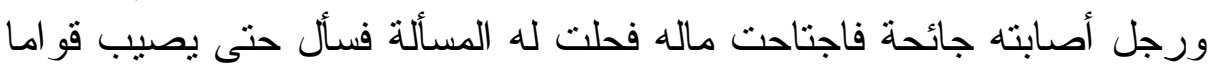

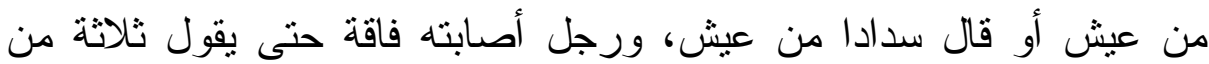

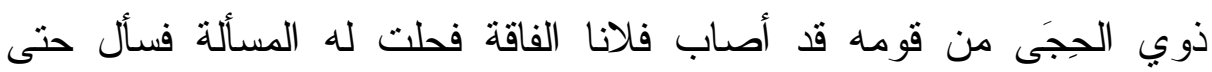
يصيب قو اما من عيش أو سدادا من عيش ثم بمسك، وما سو اهن اهن من المسألة

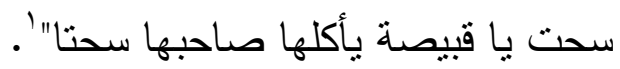
وقبل تكامل نظام المجتمع الإسلامي في المدينة المنورة و اتساع مو ارد الدولة، كان النبي صلى الله عليه وسلم لا بسدد الديون عن المدينين، فعن أبي هريرة

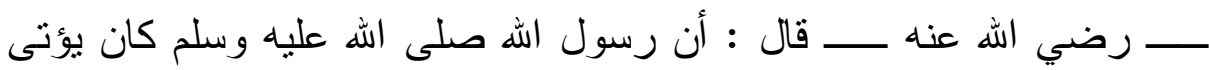

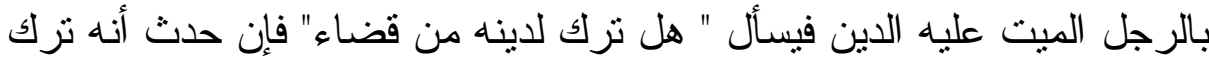
وفاء صلى عليه، وإلا قال " صلو العلى صاحبكم"، وبعد أن فتح الله عليه

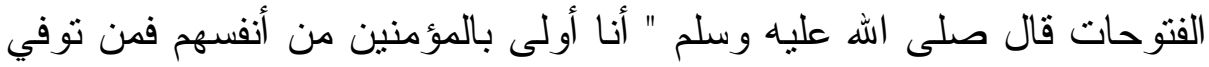

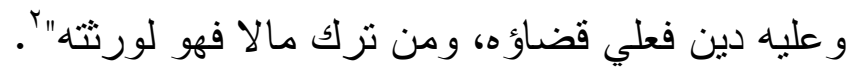
وتهدف الصور السابقة إلى تحقيق رفع الظلم و إقامة العدل بين المتعاملين في السوق وتثبيت الأخلاق و التعاون و المحبة فيه، و ومنع استغلال حاجة الناس،

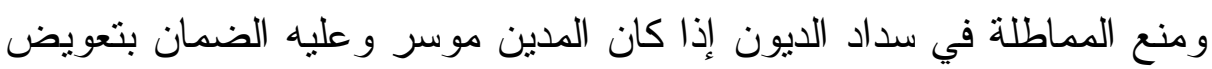

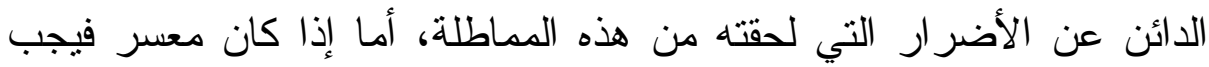

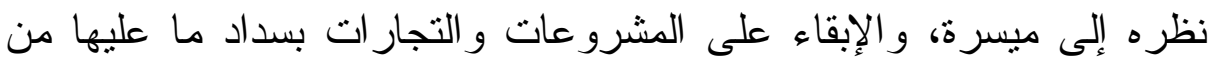

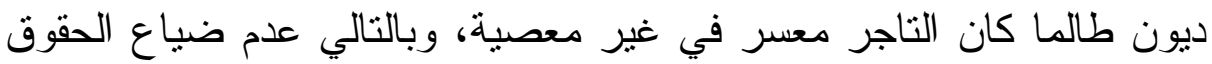

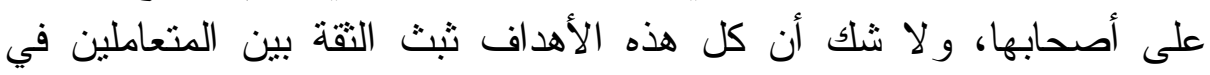

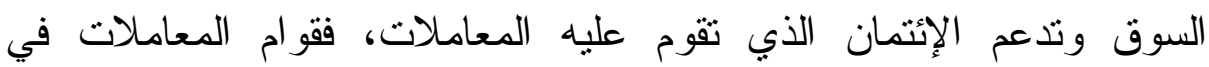

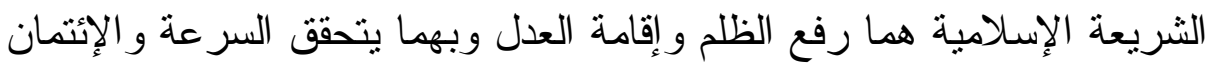

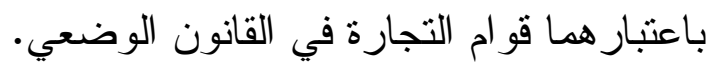

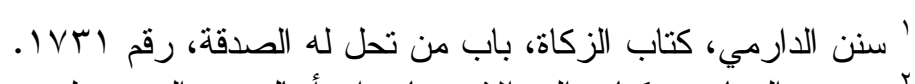

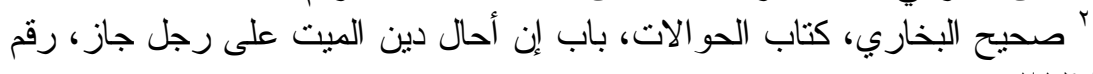

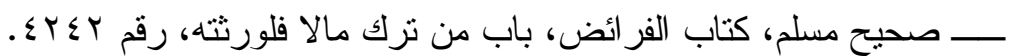




\section{المبحث الثالث}

\section{همقارنة بسين الفقه الإسلاهي والقانون الوضهي}

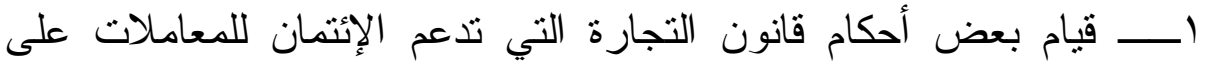

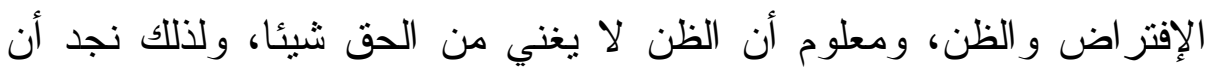

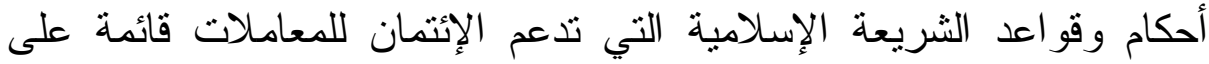
اليقين و الحق، حيث القاعدة هي أن اليقين لا يز ال بالثك.

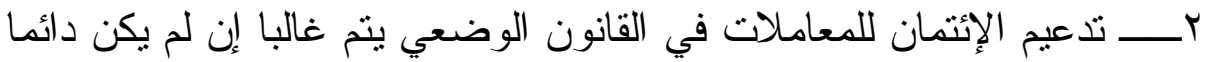

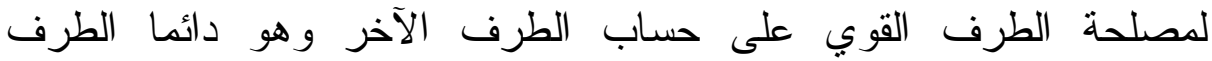

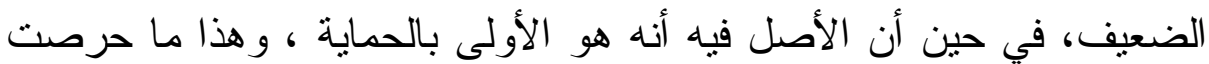

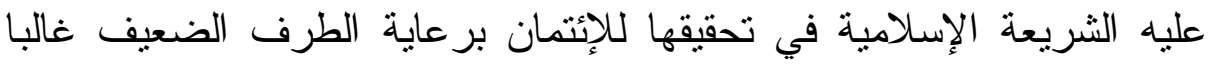

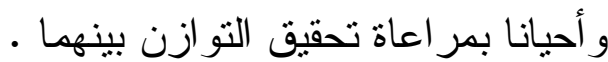

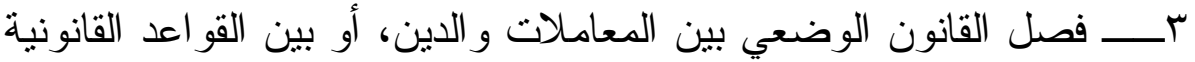

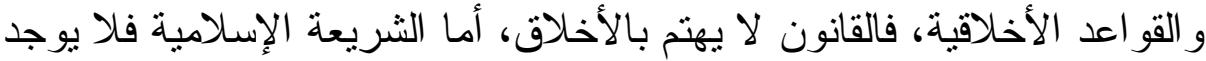

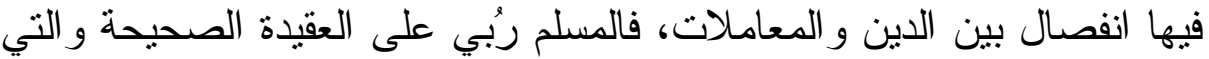

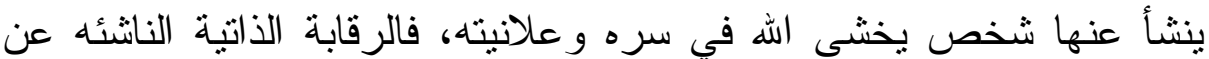
عقيدة المسلم وعباداته كفيلة بتحقيق التقة بين المتعاملين في السوق وتداعيم الإئتمان للمعاملات، لذلك قيل بأن " الدين المعاملة".

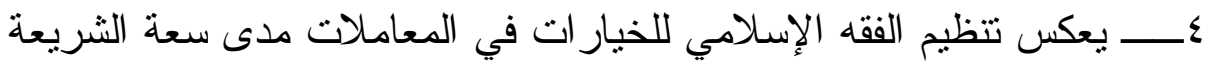

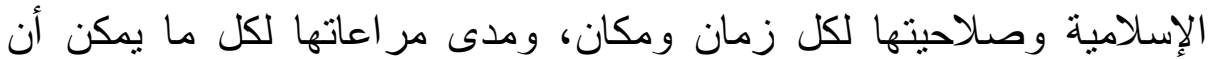

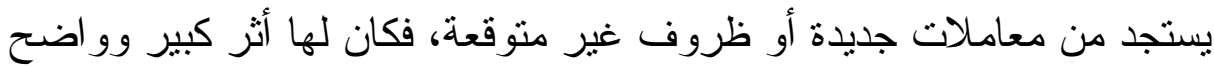
في تحقيق الثقة بين المتعاملين وتدعيم الإنتمان للمعاملات، من خلال رفئ رفع

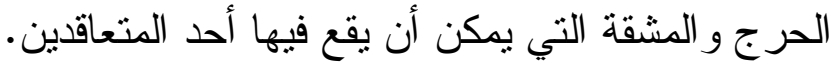

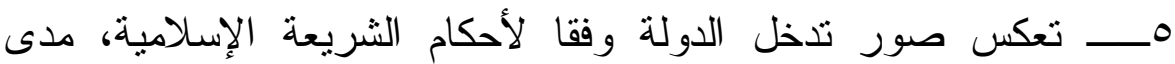

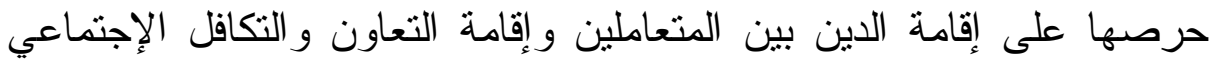

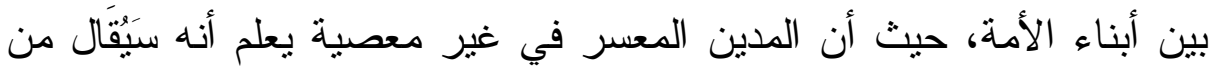

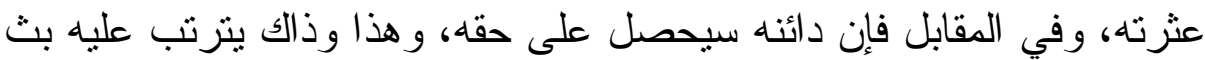
التقة بين المتعاملين في السوق وتدعيم الإئتمان للمعاملات أيا كانت طبيعتها.

\section{تم بعون الله ونضله}


